College of William \& Mary Law School William \& Mary Law School Scholarship Repository

2004

\title{
Same Struggle, Different Difference: ADA Accommodations as Antidiscrimination
}

Michael Ashley Stein

\section{Repository Citation}

Stein, Michael Ashley, "Same Struggle, Different Difference: ADA Accommodations as Antidiscrimination" (2004). Faculty Publications. 1462.

https://scholarship.law.wm.edu/facpubs/1462

Copyright c 2004 by the authors. This article is brought to you by the William \& Mary Law School Scholarship Repository. https://scholarship.law.wm.edu/facpubs 


\title{
University of Pennsylvania Law Review FOUNDED 1852
}

Formerly

American Law Register

\section{ARTICLES}

\section{SAME STRUGGLE, DIFFERENT DIFFERENCE: ADA ACCOMMODATIONS AS ANTIDISCRIMINATION}

\begin{abstract}
MICHAEL ASHLEY STEIN ${ }^{\dagger}$
The Americans with Disabilities Act (ADA) was heralded as an "emancipation proclamation" for people with disabilities, one that would achieve their equality primarily through its reasonable accommodation requirements. Nevertheless, both legal commentators and Supreme Court Justices assert that the ADA's employment mandates distinguish the ADA from earlier antidiscrimination measures, most notably Title VII, because providing accommodations results in something more than
\end{abstract}

\footnotetext{
${ }^{\dagger}$ Associate Professor, William \& Mary School of Law; Visiting Scholar, Harvard Law School (2004-2005). Many thanks to Michael Abramowicz, Samuel Bagenstos, Neal Devins, John Donohue, Davison Douglas, Samuel Estreicher, Christine Jolls, Mark Kelman, Linda Krieger, Martha Minow, Michael Selmi, and Elaine Shoben for their comments; to Sarah Black, Jeffrey Spann, and especially Joseph Schouten for their research assistance; to David Wilkins for an incredible heart-to-heart; and to Penelope Stein for asking uncompromisingly difficult questions. I benefited from presenting this Article to workshops at Berkeley, Boston College, lowa, New York University, and Northwestern. My research was funded by an American Counsel of Learned Societies Andrew W. Mellon Fellowship. This Article is dedicated to the memory of the Hon. A. Leon Higginbotham, Jr, who understood.
} 
equality for the disabled. The Article challenges this prevalent belief by arguing that ADA-mandated accommodations are consistent with other antidiscrimination measures in that each remedies exclusion from employment opportunity by questioning the inherency of established workplace norms, and by engendering cost when altering those norms. It then places the ADA within historical context by illustrating how nowoutdated social conventions about other workers with perceived atypical biological identities, particularly women and African Americans, persist in keeping workers with disabilities from equal labor market participation. Finally, the Article demonstrates how ADA accommodation expenses are an appropriate and reasonable remedy and explains why, for both economic and prudential reasons, disability-related accommodations must operate as antidiscrimination provisions (rather than as tax-andspend subsidies) in order to alter social attitudes towards the disabled. The Article concludes with some thoughts on what extra-judicial factors could facilitate the ADA's transformative agenda.

I. THE CANONICAL PARADIGM OF DISABILITY DISCRIMINATION ....... 586

A. Defining Employment Discrimination...................................586

B. The Canonical Paradigm: Dividing "Simple Discrimination" from Redistribution

C. The Canonical Paradigm Generally Questioned: When "Simple Discrimination" and (Non-ADA) Accommodation Converge... 591

D. The Canonical Paradigm Applied to the ADA: Accommodations are Redistribution

II. Challenging Where the Canonical PARADigm DIVIdes "Simple

DISCRIMINATION" FROM REDISTRIBUTION

A. Underlying Misconceptions About Accommodation Costs.......597

1. The Origin of Accommodation Costs ............................ 597

2. Inherent Inability and Fixed Identity ............................. 604

B. The Lessons of History ..........................................................608

1. The Inherent Inability of Women ................................6 609

2. The Fixed Identity of African Americans ..................... 612

3. Civil Rights Always Engender Cost ............................... 616

C. The Continuum of Perceived Biological Difference................. 622

1. Links in the Civil Rights Chain .................................... 622

2. A Unique Civil Rights Chronology .................................626

3. Old Stereotypes Die Hard: The Supreme Court.............. 629

III. ADA ACCOMMODATIONS AS ANTIDISCRIMINATION ....................6 636

A. An Appropriate Antidiscrimination Remedy ..........................6.637

1. Artificial Exclusion ............................................... 637

2. Universal Design.................................................. 640

B. A Reasonable Antidiscrimination Remedy ............................ 645

1. Reasonable Cost ................................................... 646



C. A Properly Allocated Antidiscrimination Remedy .................. 649

1. Policy Choices .............................................................. 650 
2. Economic Efficiency

3. Prudential Propriety

\begin{abstract}
Legislation is powerless to eradicate racial instincts or to abolish distinctions based upon physical differences....
\end{abstract}

[W]oman's physical structure and the performance of maternal functions place her at a disadvantage . . . . [S] he is not an equal competitor with her brother.

\title{
INTRODUCTION
}

Modeled after existing civil rights statutes, and passed with great flourish, the Americans with Disabilities Act (ADA) ${ }^{3}$ was heralded as an "emancipation proclamation" for people with disabilities. ${ }^{4}$ At the heart of the statute, and intended as the most expedient method of bringing about social and economic equality for the disabled, are the ADA's employment provisions. ${ }^{5}$ In pertinent part, Title I compels employers to provide reasonable accommodations to "qualified" employees with disabilities. ${ }^{6}$ By placing this obligation upon employers,

${ }^{1}$ Plessy v. Ferguson, 163 U.S. 537, 551 (1896).

${ }^{2}$ Muller v. Oregon, 208 U.S. 412, 421-22 (1908).

${ }^{3}$ Pub. L. No. 101-336, 104 Stat. 327 (1990) (codified as amended at 42 U.S.C. $\$ \S$ 12101-12213 (2000)).

${ }^{4}$ Two legislators are credited with this description. See 136 CONG. REC. S9689 (daily ed. July 13, 1990) (statement of Sen. Harkin) ("The ADA is, indeed, the 20th century emancipation proclamation for all persons with disabilities."); 135 CONG. REC. S10789 (daily ed. Sept. 7, 1989) (statement of Sen. Kennedy) ("In a sense, this legislation is an emancipation proclamation for the disabled, and America will be better."). For an overview of the ADA, including the genesis of many of its provisions, see Robert L. Burgdorf Jr., The Americans with Disabilities Act: Analysis and Implications of a SecondGeneration Civil Rights Statute, 26 HARV. C.R.-C.L. L. REV. 413 (1991). For a detailed account of the politics underlying the ADA's passage, see JOSEPH P. SHAPIRO, NO PITY: PEOPLE WITH DISABILITIES ForGING A NEW CIVIL RIGHTS MOVEMENT 105-41 (1993).

${ }^{5}$ The influence of disability rights advocates in "selling" the ADA to Congress on autonomy grounds, as well as the way in which the Supreme Court might be amenable to this conception, are set forth in Samuel R. Bagenstos, The Americans with Disabilities Act as Welfare Reform, 44 WM. \& MARY L. REv. 921, 985-1026 (2003).

${ }^{6}$ To be considered qualified, individuals must be capable of performing the essential job functions of the positions they seek, either with or without the provision of reasonable accommodations. 42 U.S.C. $\$ 12111(8)$. Although this mandate is fundamental to disability-based employment discrimination, neither the ADA nor interpreting courts have provided much guidance on how to determine the reasonableness of accommodations. I set forth an initial, hopefully useful, economic framework in Michael Ashley Stein, The Law and Economics of Disability Accommodations, 53 DUKE L.J. 79 (2003). 
Congress intended to remedy the historical exclusion of disabled workers from the labor market, which it documented during hearings on the $\mathrm{ADA}^{7}$ Consequently, when a nearly unanimous Congress passed the statute, it was in large part to "guarantee" workers with disabilities "a level playing field."

Nevertheless, legal scholars analyzing Title I's employment accommodation mandates with approbation, opprobrium, or agnostic indifference assert that those directives distinguish the ADA from other antidiscrimination measures, most notably Title VII of the Civil Rights Act of 1964 (Title VII). ${ }^{9}$ Central to this perception, which has become "canonical," is the belief that both economic reality and conceptual theory divide Title I and Title VII into two distinct varieties of regulation. "[R] eal anti-discrimination law $[s], " 11$ they aver, remedy the exclusion of similarly situated members of protected categories from workplace opportunity, and so achieve equality for certain historically marginalized groups. ${ }^{12}$ In contrast, by affirmatively requiring

\footnotetext{
${ }^{7}$ See, e.g., 42 U.S.C. $\$ 12101$ (a) (2) ("[H] istorically, society has tended to isolate and segregate individuals with disabilities, and, despite some improvements, such forms of discrimination against individuals with disabilities continue to be a serious and pervasive social problem.").

${ }^{8} 136$ CONG. REC. H2427 (daily ed. May 17, 1990) (statement of Rep. Hoyer). This metaphor is frequently used when describing ADA remedies. See, e.g., 136 CoNG. REC. H2444 (daily ed. May 17, 1990) (statement of Rep. Matsui) (expressing hope that the ADA "will make the playing field a little more even for those with disabilities to compete in the workplace"); Bonnie Poitras Tucker, The ADA's Revolving Door: Inherent Flaws in the Civil Rights Paradigm, 62 OHIO ST. L.J. 335, 341 (2001) (arguing that the ADA's "entire focus" is "on equalizing the playing field for people with disabilities").

${ }^{9}$ See Pub. L. No. 88-352, 778 Stat. 241 (codified at 42 U.S.C. $\$ \S 2000$ (e)$2000(e)(17)(2000)$ ) (barring employment discrimination on the basis of race, color, religion, sex, and national origin).

${ }^{10}$ To be consistent with previous scholarship, I have borrowed this term from Christine Jolls, Antidiscrimination and Accommodation, 115 HARV. L. REV. 643, 643-44 (2001). At the same time, I express trepidation in doing so given that the word connotes not only a dominant approach, but also one whose validity is recognized. The latter definition is inaccurate because the prevailing view of disability accommodation-which this Article shows to be theoretically incorrect, ahistorical, and counterfactual-has arisen without adequate vetting, and thus should not be given such credibility.

${ }^{11}$ Erickson v. Bd. of Governors, 207 F.3d 945, 951 (7th Cir. 2000). Curiously, Judge Easterbrook's endorsement refers to the Age Discrimination in Employment Act of 1967, Pub. L. No. 90-202, 81 Stat. 602 (codified as amended at 29 U.S.C. $\$ \S 621-34$ (1988)), which he subsequently distinguishes from the ADA. Erickson, 207 F.3d at 95152.

${ }^{12}$ The contingent notion of what comprises equality within the employment experience of disabled workers is addressed in Parts II and III of this Article. Arriving at a broader, more ecumenical definition of equality is at the heart of much jurisprudential scholarship, notably that of John Rawls and Ronald Dworkin. That enterprise is be-
} 
employers to provide reasonable accommodations to existing or potential workers with disabilities, the ADA does more than simply level an uneven playing field. Compelling employers to accommodate disabled workers, these scholars agree, pushes both the workplace equilibrium and its financial calculus beyond equality, and thus differentiates the ADA from its predecessors. The conception of disabilityrelated accommodations being distinct from Title VII antidiscrimination prohibitions is so pervasive that it has influenced the Supreme Court's ADA jurisprudence. ${ }^{13}$

An important article by Christine Jolls questions this entrenched view by noting that antidiscrimination and accommodation measures are not wholly separate and immiscible. ${ }^{14}$ Instead, as Jolls points out, an overlap exists between the two regulatory devices, at least so far as the way in which remedies for disparate impact discrimination can parallel the provision of accommodations. ${ }^{15}$ I agree with Jolls that confluence exists, but carry her point much further: ADA-mandated accommodations resemble antidiscrimination remedies not simply due to their comparable results, but because fundamentally they are antidiscrimination remedies. Moreover, because this Article goes beyond iconoclasm and on toward reformation, I argue that ADAmandated accommodations are an essential normative device for effectuating equality on behalf of people with disabilities. ${ }^{16}$

This Article challenges the prevailing interpretation of the ADA by arguing that the statute is consistent with other antidiscrimination regulations in remedying historical inequities. It supports this asser-

yond the scope of this Article.

${ }^{13}$ See infra Part II.C.3. Elsewhere, I have very briefly explored how the Court also views disability accommodations as a threat to the governing occupational hierarchy by eroding employers' control of the workplace. Michael Ashley Stein, Disability, Employment Policy, and the Supreme Court, 55 STAN. L. REV. 607, 632-33 (2002).

${ }_{15}$ See generally Jolls, supra note 10.

${ }^{15}$ Id. at 651-56.

${ }^{16}$ Jolls's assertions can be read to include ADA-mandated accommodations, although she does not provide any disability-related examples. Id. at 645 . Conversely, Samuel Bagenstos has recently asserted the moral equivalence (but not the economic confluence) of disability accommodations remedying intentional (disparate treatment) exclusion, but did not address inadvertent (disparate impact) exclusion. See Samuel R. Bagenstos, "Rational Discrimination, "Accommodation, and the Politics of (Disability) Civil Rights, 89 VA. L. REV. 825,834 (2003) (“[M]y definition of 'antidiscrimination” leaves out an important aspect of what we usually call antidiscrimination law-the prohibition on practices that have a disparate impact on members of protected classes ...."). This Article addresses the lacunae left by their valuable work in arguing for the historical, economic, and prudential confluence of ADA-mandated accommodations with Title VII remedies. 
tion by demonstrating that society views physically atypical workers, including women, African Americans, and people with disabilities, along a continuum, adjusting most slowly to those differences with which it is least familiar. ${ }^{17}$ During this acclimatization period, various biases and misperceptions are slowly stripped away. For example, assertions once regularly made about women and African Americans, respectively, are now considered unacceptable. Parallel biases and misperceptions persist, however, in unnecessarily excluding people with disabilities from the workplace because they are held out as true and rational beliefs. Instead of viewing disabled workers separately from other biologically atypical employees, I argue throughout this Article on behalf of the position enunciated in the disability rights aphorism: "same struggle, different difference."18 This Article also illustrates how disability-related accommodation costs remedy historical exclusion of the disabled from mainstream society in an appropriate and reasonable manner. Finally, I argue that ADA accommodations, for economic and prudential reasons, need to operate as antidiscrimination provisions, rather than as tax-and-spend subsidies, to achieve their goal of transforming societal attitudes towards workers with disabilities. ${ }^{19}$

Part I begins by setting forth an ecumenical definition of employment discrimination. Next, it presents the economically flavored canonical paradigm which differentiates "simple discrimination," meaning workplace exclusion remedied by regulations that result in equality, from redistribution, which is seen as an affirmative duty going beyond the norm of equality because it transfers resources from employers to employees. Part I then describes Christine Jolls's questioning of the supposed absolute dichotomy between antidiscrimination regulations and non-ADA accommodation mandates. It concludes by describing how academic commentators have applied the

${ }^{17}$ Although a full exploration is beyond the scope of this Article, I will briefly note my belief that gay, lesbian, bisexual, and transgendered people are the next group of socially marginalized individuals with perceived biological atypicality in line for empowerment. Infra Part II.C.1.

${ }^{18}$ For a depiction of this apophthegm in practice, see Smithsonian Inst., Nat. Museum of Am. History, Disability Rights Movement TShirts, at http://americanhistory.si. edu/disabilityrights/exhibit_t_shirts_full2.html (2000) (last accessed Nov. 2, 2004).

${ }_{19}$ My position is not an unqualified one. As I have stated elsewhere, there are some workers with disabilities for whom accommodations are neither legally required nor practically achievable. See Stein, supra note 6, at 144-77 (diagramming disability accommodations along a continuum of costs, the most expensive of which are neither $\mathrm{ADA}-$ required nor socially beneficial). For a more detailed explanation, see infra Part III. 
canonical paradigm to $\mathrm{ADA}$ accommodations, with the result that the statute is viewed as something other than a "pure" antidiscrimination provision.

Working within the received framework, Part II challenges where the canonical paradigm draws a line between simple discrimination and redistribution as it relates to $\mathrm{ADA}$ accommodations. It begins by illustrating a flawed methodological assumption underlying the analysis: the notion that accommodation costs are (internally) engendered due to the inherent lesser capability of the disabled, rather than (externally) caused by socially contingent conditions. Part II then demonstrates how similar estimations were once rolled out in opposition to equality arguments made on behalf of women and African Americans; further, that achieving equality through civil rights provisions always engenders cost because those laws change an entrenched and needlessly exclusionary status quo. Moreover, it argues that the ADA is the most recent measure to empower individuals that mainstream society views as biologically atypical. While those conventions are now considered outdated as relating to employees on the basis of their sex or race, Part II shows how the unique civil rights chronology of the disabled, in combination with enduring misperceptions about the group, persists in influencing the Supreme Court's assessment of workers with disabilities.

Part III argues that ADA-mandated accommodations are fundamental antidiscrimination measures that effectuate no more than equality. In support of this assertion, Part III maintains that disabilityrelated accommodations are an appropriate antidiscrimination remedy because, like Title VII and other more traditional regulations, the ADA remedies the avoidable exclusion from workplace opportunity of a targeted group. It further asserts that the ADA is a reasonable antidiscrimination remedy in that the costs it imposes are circumscribed, and because it requires that those expenses be incurred in a manner proportionate to the resources of employers. Finally, Part III provides economic and prudential justifications for why the ADA is more properly conceived of as antidiscrimination legislation than as a tax-and-spend subsidy for disability-related accommodations. The Article concludes with some thoughts on what factors exogenous to the ADA could help the statute's future implementation. 


\section{THE CANONICAL PARADIGM OF DISABILITY DISCRIMINATION}

Prohibited discrimination arises from the unequal treatment of otherwise equal individuals who are also members of protected classes. Prevailing analyses of employment discrimination law are economic in nature, dividing labor market regulations between those designed to prevent simple discrimination and those calculated to redistribute resources. One commentator has pointed out that overlap exists between the two approaches in the sense that remedies brought under antidiscrimination protections sometimes bring about the same economic effect as remedies attempted under (non-ADA) accommodation measures. ${ }^{20}$ Nonetheless, nearly all legal scholars characterize the ADA as a redistributive measure and distinguish it in kind from traditional antidiscrimination legislation.

\section{A. Defining Employment Discrimination}

Employment discrimination may be defined as the different treatment of otherwise equal individuals on the basis of certain protected group-based characteristics, such as race or sex. ${ }^{21}$ As described below, the issue of whether workers with perceived atypical identity characteristics are otherwise equal begs the very question raised. ${ }^{22}$ Consequently, whether the biological differences of particular individuals ("only women are capable of giving birth") translate into functional limitations that are immutable ("women who give birth are inherently less capable of working immediately thereafter") or contrived limitations ("allocating physical recovery time for women who have given birth is different from allocating physical recovery time for other workers, such as those who have contracted the flu"), or socially

${ }^{20}$ Jolls, supra note 10 , at 651-56.

${ }^{21}$ For a discussion of why group membership, as opposed to individual circumstance, is necessary to justify antidiscrimination protection for people with disabilities, see Samuel R. Bagenstos, Subordination, Stigma, and "Disability," 86 VA. L. REV. 397, 42268 (2000) (arguing that ADA coverage ought to be limited to those individuals whose disability-related stigma subjects them to systematic disadvantage); Mark Kelman, Does Disability Status Matter?, in AMERICANS WITH DISABILITIES: EXPLORING IMPLICATIONS OF THE LAW FOR INDIMDUALS AND INSTITUTIONS 91, 97-99 (Leslie Pickering Francis \& Anita Silvers eds., 2000) [hereinafter EXPLORING IMPLICATIONS] (proposing that norms are best enforced as group, rather than individual, protections because the larger societal benefits stemming from the prevention of market discrimination relate to the incorporation of those groups into the social and economic mainstream).

${ }^{22}$ See infra Part II.A.l (discussing the origin of disabled employees' accommodation costs) 
contingent limitations ("women, whether child-bearing or adopting, need to stay at home to nurture their children; men who are parents can rely on their female partners or pay for child care assistance") is key to whether one views exclusion from workplace opportunity as licit or discriminatory.

Within the context of employment discrimination law, differential treatment, the practice of excluding members of a protected group from full workplace opportunity, can arise through a wide range of employer behavior. Its genesis can issue from overt animus ("I don't like Asians"), be responsive to the biased perspectives or "tastes" of third parties ("my clients and/or customers don't like Asians"), originate in unproven assumptions of social convention ("Asians are too diffident"), rely on empirically incorrect proxies in the absence of accurate information ("Asians lack communication skills"), or use employment practices later shown to be irrelevant or unwarranted ("English-speaking telephone operators must be native English speakers").

Although divining an employer's "true" motivation is pertinent to traditional doctrinal analysis, it is not relevant to application of the canonical paradigm. This is because, from an economic perspective, the issue of what motivates employers is immaterial to the inquiry of whether ADA-mandated accommodations implicitly redistribute wealth from employers to disabled employees. Whether the denial of a reasonable accommodation was precipitated by animus, inadvertence, or some other noneconomic reason is likewise not material to this calculus. ${ }^{23}$

\section{B. The Canonical Paradigm: Dividing "Simple Discrimination" from Redistribution}

The clearest proponent of the canonical paradigm of employment discrimination is Mark Kelman. ${ }^{24}$ Kelman distinguishes between the

${ }^{23}$ Infra Parts I.B-I.D.

${ }^{24}$ See Mark Kelman, Strategy or Principle?: The Choice Between ReguLATION AND TAXATION 8-9 (1999) [hereinafter KelmaN, STRATEGY OR PRINGIPLE] ("[I]t is surely the case that insofar as the ADA demands that private actors provide beneficial, non-market-rational treatment to certain customers (or workers), it could be said to function as a broad-gauged redistributive social program, designed to funnel social resources to a class of deserving beneficiaries." (footnote omitted)); MARK KELMAN \& GILLIAN LESTER, JUMPING THE QUEUE: AN INQUIRY INTO THE LEGAL TREATMENT OF STUDENTS WITH LEARNING DISABILITIES 195-98 (1997) (differentiating between rights to be free from discrimination and redistributive policies); Kelman, supra note 21, at 96 ("It is also possible to see the demand for accommodation as the demand for resource redistribution."); Mark Kelman, Market Discrimination and Groups, 53 
societal norms that exist against "simple discrimination" and those norms that mandate the provision of "accommodation." ${ }^{25}$ Simple discrimination occurs when an employer treats an individual differently from other employees or job applicants, despite the fact that she is equal with respect to all "relevant" characteristics. ${ }^{26}$ According to Kelman, a 'relevant' characteristic is one that does not affect the employer's economic function, meaning that the employer experiences no additional costs from employing her (i.e., that her net marginal product is the same as that of other employees). ${ }^{27}$ Therefore, plaintiffs asserting the right to be free from simple discrimination are asking only that employers treat them as equal to those who are "equivalent sources of money." In Kelman's scheme, it is important to note, freedom from simple discrimination exists as a right rather than as a "colorable claim" because its application does not involve the expenditure of limited social and economic resources. ${ }^{29}$

STAN. L. REV. 833, 880 (2001) [hereinafter Kelman, Market Discrimination] ("What is most striking... about these transparently redistributive antidiscrimination programs is that they redistribute resources, not money, to increase levels of social inclusion"). It bears noting that, insofar as the ADA is concerned, Kelman is agnostic on whether accommodations ought to be funded through regulation or subsidies. The thrust of his argument is that we ought to recognize the ADA as being redistributive in nature.

${ }^{25}$ See KELMAN \& LESTER, supra note 24, at 195-226 (discussing these differences in policy toward students with learning disabilities); Kelman, supra note 21, at 92 (stating that the ADA provides two remedies, including "protection against 'simple discrimination" and "reasonable accommodation"); Kelman, Market Discrimination, supra note 24, at 834 (same).

${ }^{26}$ See Kelman, Market Discrimination, supra note 24, at 840 (stating that the ADA "prohibits 'simple discrimination' (differential treatment despite equality along 'relevant' dimensions)"); see also Kelman, supra note 21, at 93 ("Insofar as the employer or owner cares about the person's status or traits that are irrelevant to such person's economic function, he or she is breaching the duty to avoid simple discrimination."). Whether a characteristic is relevant is crucial to distinguishing between simple discrimination and redistribution. Because Kelman does not view disability-related exclusion arising from pure capitalistic rationality as relevant, he characterizes counterbalancing accommodations as redistribution; in contrast, because I perceive accommodations as correcting avoidable exclusion, $I$ interpret their denial as simple discrimination. Infra Part III.A.l.

${ }^{27}$ See Kelman, Market Discrimination, supra note 24, at 841 ("A worker's net marginal product is equal to the value of the increase in goods or services the firm will produce if the employee is added to the firm, net of the added costs that firm will incur if she were employed by that firm."); see also KELMAN \& LESTER, supra note 24, at 199-208 (maintaining that employers are chiefly concerned with individual net productivity rather than with aggregate gross production values); Mark Kelman, Concepts of Discrimination in "General Ability" Job Testing, 104 HARV. L. REV. 1157, 1198-1204 (1991) [hereinafter Kelman, Job Testing] (same).

${ }^{28}$ Kelman, Market Discrimination, supra note 24, at 835.

${ }^{29}$ Id. at 834. 
In contrast to an individual seeking relief from simple discrimination, an employee who requests an accommodation "concedes" that both "business rational[ity]" and lower net productivity (due to accommodation expense) "differentiates" her from a non-requesting employee. $^{30}$ In asking her employer to disregard additional input costs, Kelman avers, the employee has made a "straightforward demand for resource redistribution." "\$1 In economic terms, an entity that is required to provide an accommodation has been subjected to "an implicit 'regulatory tax" whose proceeds provide in-kind (as opposed to in-cash) benefits to accommodation recipients. ${ }^{32}$ Kelman argues further that the simple discrimination model imposes an unlimited cost-qualified duty, while the accommodation model requires claimants to compete against all other demands for available social resources. ${ }^{33}$ Finally, Kelman distinguishes the two norms on the ground that the non-accommodator bases her decision on retaining real social resources (i.e., acting in an economically rational manner) rather than on personal preferences (meaning, idiosyncratic or illegitimate motivations). ${ }^{34}$

At this point it is important to note that, from a jurisprudential perspective, Kelman's paradigm of simple discrimination contrasted with redistribution parallels the philosophical schema dividing formal (or corrective) justice from distributive (or material) justice. The first group of terms refers to the notion of treating similarly situated indi-

${ }^{30} I d$. at 843. Accordingly, the employee "does not claim to merit the treatment she asks for because she has the same relevant traits as the person who has received better treatment." Id. But see Ron Amundson, Disability, Handicap, and the Environment, 23 J. Soc. PHIL. 105, 113 (1992) ("Someone whose disadvantage occurs as a result of a social decision has a more obvious claim for social remediation.").

${ }^{31}$ Kelman, Market Discrimination, supra note 24, at 880 . At the same time, it should be noted that Kelman has consistently pointed out that employers frequently believe they are dealing with disabled employees whose traits make them less net-productive, when in fact those workers would be equally net-productive but for the noninclusive organizational decisions made by those same employers. See, e.g., id. at 846-48, 877-78 $\mathrm{n} .71$ (asserting that employers' argument that it is costly to hire disabled employees is untenable and disabled employees "will be just as net productive, prospectively, as those [with whom] they compete").

${ }^{32}$ Id. at 880.

${ }^{33}$ See id. at 852 (“[T]hose seeking protection from simple discrimination possess 'rights' claims while those seeking accommodations are making 'distributive' claims."). This is because "[a]ccommodation claims are best conceived of as zero-sum, distributive claims to a finite pot of redistributed social resources, competing not only with the demands of others who seek accommodation ... but with all claimants on state resources." Id.

${ }^{34}$ See id. at 853-54 ("The nonaccommodating defendant (and taxpayer) attempts to retain (or save) real social resources...,"). 
viduals in a similar manner. ${ }^{35}$ The second category is drawn from the field of social justice, and advocates treating all individuals equally, whether or not they are in fact equal. ${ }^{36}$ This model (although not well articulated) underlies the canonical academic examination of the $\mathrm{ADA}$, as well as that of the Supreme Court. ${ }^{37}$ I concur with Kelman's paradigm for examining employment discrimination law to the extent that it parses simple discrimination from redistribution, but not in the manner in which it has been applied to the ADA. Consequently, I question the point at which the line between formal and distributive justice is drawn with respect to disability-related accommodations, argue that the nexus ought to be shifted, and justify those assertions. ${ }^{38}$

${ }^{85}$ See, e.g., JOHN STUART MILL, UTILITARIANISM (1861), reprinted in ESSAYS ON Ethics, Religion And SOCIETy 205, 243 (F.E.L. Priestley \& J.M. Robson eds., 1969) ("[I] $\mathrm{t}$ is, by universal admission, inconsistent with justice to be partial; to show favour or preference to one person over another, in matters to which favour and preference do not properly apply."); HENRY SIDGWICK, THE METHODS OF ETHICS 267 (7th ed. 1981)(1907) (" $[T]$ he only sense in which justice requires a law to be equal is that its execution must affect equally all the individuals belonging to any of the classes specified in the law."). For perhaps the earliest exposition of the theory that like things should be treated alike, see ARISTOTLE, NICOMACHEAN ETHICS $118 \S 1131 \mathrm{a}-\mathrm{b}$ (Martin Ostwald trans., 1962).

${ }^{36}$ See, e.g., JOHN RAwls, A ThEORY OF Justice 54 (rev. ed. 1999) (1971) (defining distributive justice generally as the theory that "[a]ll social values-liberty and opportunity, income and wealth, and the bases of self-respect-are to be distributed equally unless an unequal distribution of any or all of these values is to everyone's advantage"); AMARTYA SEN, INEQUALITY REEXAMINED 73-87, 129-52 (1992) (advancing Rawls's conception of distributive justice by exploring the dynamic interplay of equality and diversity). A few commentators have applied Rawlsian theory to people with disabilities. See, e.g., Carlos A. Ball, Autonomy, Justice, and Disability, 47 UCLA L. REV. 599, 635-51 (2000) (arguing that redistribution of material goods sufficient to make disabled people functional, and hence autonomous, is a moral obligation on society); Norman Daniels, Justice and Health Care, in HEALTH CARE ETHICS: AN INTRODUCTION 317-20 (Donald VanDeVeer \& Tom Regan eds., 1987) (maintaining that society ought to redistribute resources in the form of health care to those disabled people whose receipt would enable their function); Ronald Dworkin, What is Equality? Part 2: Equality of Resources, 10 PHIL. \& PUB. AfF. 283, 292-304 (1981) (suggesting that people with disabilities should receive wealth redistribution as part of a behind-the-veil insurance schema). In contrast to this position, Mark S. Stein asserts that Rawls's theory would mandate distribution of social resources either to the poor or to the "severely disabled," both of which would be incorrect from a utilitarian perspective. Mark S. Stein, Rawls on Redistribution to the Disabled, 6 GEO. MASON U. L. REV. 997, 1003-12 (1998). This is an odd gloss as, empirically, the population of those two groups largely overlap. U.S. CENSUS BUREAU, CENSUS SUMMARY FILE 4 (1999), available at http://factfinder.census.gov (Poverty Status in 1999 by Disability Status by Age for the Population).

${ }^{37}$ Infra Parts I.D, II.C.3.

In ${ }^{38} a$ Parts II-III. 


\section{The Canonical Paradigm Generally Questioned: When "Simple Discrimination" and (Non-ADA) Accommodation Converge}

Christine Jolls questions received wisdom by noting that antidiscrimination and accommodation regulations occasionally overlap to the extent that some remedies for disparate impact discrimination are actually accommodation requirements. ${ }^{39}$ These "cases of equivalence," she argues, are economically indistinguishable from certain aspects of antidiscrimination law in the outcomes that they mandate. ${ }^{40}$ Thus, assertions about the fundamental distinctiveness of antidiscrimination and accommodation mandates are unpersuasive. ${ }^{41}$

Jolls offers five practical examples in support of her thesis of overlap between disparate impact and accommodation and demonstrates how eviscerating disparate impact in each necessitates the provision of an accommodation-type remedy. ${ }^{42}$ Respectively, these are facially neu-

${ }^{39}$ See Jolls, supra note 10, at 645, 684-97 (recognizing similarities and areas of overlap between accommodation requirements and antidiscrimination statutes).

${ }^{40}$ Sharon Rabin-Margalioth, Anti-Discrimination, Accommodation and Universal Mandates-Aren't They All the Same?, 24 BERKELEY J. EMP. \& LAB. L. 111, 137 (2003). RabinMargalioth advances Jolls's arguments in another direction by averring that, from an economic perspective, universal mandates (i.e., provisions that affect all workers regardless of identity characteristics) form a third equivalence category. Id. at 137-38. I am in agreement with her general conclusion, but note that the lines she draws in reaching her deduction are sometimes overly bright. Thus, while laws affecting overtime pay, such as the Fair Labor Standards Act, 29 U.S.C. $\$ \S 207-219$ (2002), are clearly among the category of universal mandates, some might also catalog Title VII's disparate treatment component as a universal mandate in that it is, in theory, ecumenical in its reach (hence, the reason why reverse discrimination suits can be brought by white males). At the same time, disparate treatment can be found in traditional antidiscrimination legislation, such as the Age Discrimination in Employment Act, 29 U.S.C. $\$ \$ 621-634$ (2002), which by definition only applies to individuals over the age of forty. There have been several clever responses to these ambiguities. See LAWRENCE M. FRIEDMAN, YOUR TIME WILl COME: THE LAW OF AGE DISCRIMINATION AND MANDATORY RETIREMENT 15 (1984) (musing that with time, everyone has an opportunity to come under the ADEA's aegis); John J. Donohue III, Comment, Understanding the Reasons for and Impact of Legislatively Mandated Benefits for Selected Workers, 53 STAN. L. REV. $897,898 \mathrm{n} .1$ (2001) (describing the ADEA as an "exception to the general rule of uniform applicability of a federal antidiscrimination law."); see also Christine Jolls, Accommodation Mandates, 53 STAN. L. REV. 223, 226 (2000) (observing that because certain individuals, notably those in classically protected categories, are more likely to assert Title VII claims, the statute can be properly conceived of as antidiscriminatory).

${ }^{41}$ A similar argument was previously made in the context of pregnancy-based discrimination by Reva B. Siegel, Note, Employment Equality Under the Pregnancy Discrimination Act of 1978, 94 YALE L.J. 929, 940-46 (1985), and by Linda Hamilton Krieger, Fore word-Backlash Against the ADA: Interdisciplinary Perspectives and Implications for Social Justice Strategies, 21 BERKELEY J. EMP. \& LAB. L. 1, 3-4 (2000).

${ }^{42}$ What follows is drawn from Jolls, supra note 10, at 652-66. 
tral: (1) no-beard rules ${ }^{43}$ that disparately impact those African American males whose skin conditions preclude regular shaving;, ${ }^{44}$ (2) job selection criteria that tend to exclude women (notably, height and weight requirements) ${ }^{45}$ and racial groups (chiefly, standardized ability tests) $;{ }^{46}$ (3) English-only rules that adversely affect individuals with alternative national origins; ${ }^{47}$ (4) refusals of non-Family and Medical Leave Act (FMLA) ${ }^{48}$ pregnancy leave time requests disparately impacting women who bear children; ${ }^{49}$ and (5) actions effectuating policies on the grounds of business necessity that tend to exclude members of protected groups. $^{50}$

${ }^{43}$ No pun is intended here, nor in my discussion of other grooming rules, such as hair length, insofar as they affect women rather than men.

${ }^{44}$ Usually due to pseudofolliculitis. See STEDMAN'S MEDICAL DictionarY 1470 (27th ed. 2000) (defining the condition). The case discussed in text is Bradley $v$. Pizzaco of Neb., Inc., 7 F.3d 795, 799 (8th Cir. 1993), which reversed a finding of business justification for a no-beard policy at a Domino's Pizza franchise. Jolls, supra note 10, at 633 n.47.

${ }^{45}$ See, e.g., Lanning v. Southeastern Pa. Transp. Auth., 181 F.3d 478, 482 (3d Cir. 1999) (addressing a provision requiring transit police candidates to run a mile and a half in under twelve minutes). See generally David E. Hollar, Comment, Physical Ability Tests and Title VII, 67 U. CHI. L. REv. 777, 791-93 (2000) (describing the Third Circuit's application of a minimum qualifications standard to the physical ability test at issue in Lanning).

${ }^{46}$ See, e.g., Banks v. City of Albany, 953 F. Supp. 28, 36 (N.D.N.Y. 1997) (recognizing a prima facie case for Title VI discrimination where African American plaintiffs challenged fire department hiring practice rooted in personal and familial relationships). See generally Kelman, Job Testing, supra note 27, at 1159 (arguing that the use of general ability tests in employment decisions is "[not only] suspect if one reads the antidiscrimination norm expansively, but also that their use is inconsistent with the sort of meritocratic principles that mainstream conservatives, who typically support job testing, voice in interpreting that norm"). The impact of standardized education-related tests upon race is addressed in R. Richard Banks, Meritocratic Values and Racial Outcomes: Defending Class-Based College Admissions, 79 N.C. L. REV. 1029, 1070 (2001) (concluding that considering socioeconomic status, rather than just raw numbers, in the college admissions process serves to promote meritocratic goals and racial diversity).

47 See, e.g., EEOC v. Synchro-Start Prods., Inc., 29 F. Supp. 2d 911, 911-12 (N.D. Ill. 1999) (involving alleged disparate impact of a rule that forbade the speaking of any language other than English at the worksite). See generally S. Craig Moore, English-Only Rules in the Workplace, 15 LAB. L. 295 (1999).

${ }^{48}$ Family and Medical Leave Act of 1993, Pub. L. No. 103-3, 107 Stat. 6 (codified as amended at 29 U.S.C. $\$ \$ 2601-2654$ ). For the reason that commentators view this statute as an accommodation mandate rather than as a pure antidiscrimination provision, see supra Part I.B.

${ }^{49}$ See generally Samuel Issacharoff \& Elyse Rosenblum, Women and the Workplace: Accommodating the Demands of Pregnancy, 94 COLuM. L. REV. 2154 (1994).

${ }^{50}$ See, e.g., Lanning, 181 F.3d at 481 (vacating the judgment of the district court and holding that "a discriminatory cutoff score must ... be shown to measure the minimum qualifications necessary for successful performance of the job in question in 
Three themes common to the aforementioned examples bear noting. First, in each case, a court questioned whether a given business policy was in fact necessary to the business. Second, all of the employers were required to bear additional costs when policies causing disparate impact were abnegated. Third, those employers were compelled to hire or retain workers they had previously viewed as less capable. Jolls's article, while giving trenchant treatment to most forms of employment discrimination, does not engage the area of disabilityrelated discrimination and, more particularly, ADA accommodation claims. $^{51}$ The absence is due as much to the empirical lack of disability-related cases proceeding under disparate impact theory, as it is because her article is illustrative rather than normative. ${ }^{52}$ Building upon, but also going much further than Jolls, I argue below that ADA accommodations are an appropriate, reasonable, and properly allocated antidiscrimination remedy. ${ }^{53}$

\section{The Canonical Paradigm Applied to the ADA: Accommodations Are Redistribution}

In applying the simple discrimination versus redistribution model of employment discrimination to the $\mathrm{ADA}$, a wide spectrum of legal theorists conclude that disability-related accommodations differ in kind from more traditional antidiscrimination regulations. This is because $\mathrm{ADA}$ accommodations, which balance out inherent biological limitations, involve additional expenses relative to other civil rights requirements, which costlessly equalize externally driven restrictions. As a result, a received wisdom has developed among academics that providing accommodations raises the disabled above an equal position. $^{54}$

order to survive a disparate impact challenge").

${ }^{51}$ In an interesting gloss that does speak to the ADA, Verkerke engages Jolls's thesis that simple antidiscrimination measures and accommodation provisions overlap. While acknowledging that some overlap exists, he nonetheless avers that it is not significant enough to abandon the traditional distinction between these two classes of antidiscrimination measures. J.H. Verkerke, Disaggregating Antidiscrimination and Accommodation, 44 WM. \& MARY L. REV. 1385, 1395-1401 (2003).

${ }^{52}$ This observation is also made by Bagenstos, supra note 16 , at 828 .

53 Infra Parts III.A-III.C.

54 See Stephen F. Befort \& Holly Lindquist Thomas, The ADA in Turmoil: Judicial Dissonance, the Supreme Court's Response, and the Future of Disability Discrimination Law, 78 OR. L. REV. 27, 75 (1999) (describing the ADA's accommodation requirement as a "form of affirmative action for disabled individuals"); Robert L. Burgdorf, Jr., "Substantially Limited" Protection from Disability Discrimination: The Special Treatment Model and Misconstructions of the Definition of Disability, 42 VIL.L. L. REV. 409, 414 (1997) (arguing 
that there has been a "special treatment" approach in the interpretation and enforcement of laws prohibiting discrimination based on disability); Deborah A. Calloway, Dealing with Diversity: Changing Theories of Discrimination, 10 ST. JOHN's J. LEGAL COMMENT. 481, 491 (1995) (averring that the ADA goes beyond providing only equal treatment); John J. Donohue III, Employment Discrimination Law in Perspective: Three Concepts of Equality, 92 MICH. L. REv. 2583, 2585 (1994) (explaining that the goal of employment discrimination law is to set a protected person's wages equal to their value even in a biased market); Lisa Eichhorn, Hostile Environment Actions, Title VI, and the ADA: The Limits of the Copy-and-Paste Function, 77 WASH. L. REv. 575, 605 (2002) (contending that the ADA departs from the formal equality model of other antidiscrimination statutes); Sharona Hoffman, Corrective Justice and Title I of the ADA, 52 AM. U. L. REv. 1213, 1235-40 (2003) (arguing that the ADA deviates from the traditional civil rights model of protecting "discrete and insular" minorities); Patricia Illingworth \& Wendy E. Parmet, Positively Disabled: The Relationship Between the Definition of Disability and Rights Under the ADA, in EXPLORING IMPLICATIONS, supra note 21, at 3, 8 (discussing the difference between the ADA and Title VII); Samuel Issacharoff \& Justin Nelson, Discrimination with a Difference: Can Employment Discrimination Law Accommodate the Americans with Disabilities Act?, 79 N.C. L. REV. 307, 314-15 (2001) (distinguishing between ADA suits and other antidiscrimination litigation); George Rutherglen, Discrimination and Its Discontents, 81 VA. L. REV. 117, 145 (1995) (same); Verkerke, supra note 51, at 1387 (same); Pamela S. Karlan \& George Rutherglen, Disabilities, Discrimination, and Reasonable Accommodation, 46 DUKE L.J. 1, 3 (1996) (arguing that disabled individuals have greater protection than "women, blacks, or older workers"); Krieger, supra note 41, at 3-4 (positing the fundamental difference between Title VII and the ADA is the difference between "formal equality" and "accommodation of difference"); S. Elizabeth Wilborn Malloy, Something Borrowed, Something Blue: Why Disability Claims Are Different, 33 CONN. L. REV. 603, 608-09 (2001) (explaining the heightened duty to people with disabilities); Miranda Oshige McGowan, Reconsidering the Americans with Disabilities Act, 35 GA. L. REV. 27, 35 (2000) ("[T] he ADA appears to make a revolutionary break with the old ways of thinking about discrimination while charting a new course of affirmative obligations to ensure real equality."); Stewart J. Schwab \& Steven L. Willborn, Reasonable Accommodation of Workplace Disabilities, 44 WM. \& MARY L. REV. 1197, 1202 (2003) ("[T] he ADA expands on prior conceptions of discrimination."); Michelle A. Travis, Leveling the Playing Field or Stacking the Deck? The "Unfair Advantage" Critique of Perceived Disability Claims, 78 N.C. L. REv. 901, 951 (2000) ("[T] he ADA ... arguably goes beyond the concept of corrective justice to include a component of "distributive justice' as well."); Amy L. Wax, Disability, Reciprocity, and "Real Efficiency": A Unified Approach, 44 WM. \& MARY L. REV. 1421, 1426 (2003) ("In effect, the ADA operates as a mechanism for the broad range of taxpayers to impose 'negative externalities' on employers ....."); Carolyn L. Weaver, Incentives Versus Controls in Federal Disability Policy, in DISABILITY AND WORK: INCENTIVES, RIGHTS, AND OPPORTUNITIES 3, 5 (Carolyn L. Weaver ed., 1991) [hereinafter DISABILITY AND WORK] (arguing that the "imposition upon employers of a duty to "accommodate'" is the central flaw of the ADA); Christopher J. Willis, Comment, Title I of the Americans with Disabilities Act: Disabling the Disabled, 25 CUMB. L. REV. 715, 730 (1994) ("[T] he ADA operates as a tool which redistributes wealth from consumers and the labor force as a whole to the disabled persons who choose to invoke it."); John M. Vande Walle, Comment, In the Eye of the Beholder: Issues of Distributive and Corrective Justice in the ADA's Employment Protection for Persons Regarded as Disabled, 73 CHI.-Kent L. REv. 897, 923-25 (1998) (same).

The strongest position that can be taken from these numerous commentators is summarized by economist Sherwin Rosen:

Fundamentally the ADA is not an antidiscrimination law. By forcing employ- 
To date, the commentator who has most thoroughly applied Kelman's simple discrimination versus redistribution paradigm to the ADA has been Samuel Issacharoff, both on his own, ${ }^{55}$ and most clearly, in an article written with a co-author, Justin Nelson. ${ }^{56}$ Issacharoff was not the first scholar to conclude that Title I is distinct from Title VII, ${ }^{57}$ nor do all other commentators precisely follow that analysis. ${ }^{58}$ However, his work may be taken as emblematic of the canonical view. ${ }^{59}$

ers to pay for work site and other job accommodations that might allow workers with impairing conditions defined by the law to compete on equal terms, it would require firms to treat unequal people equally, thus discriminating in favor of the disabled.

Sherwin Rosen, Disability Accommodation and the Labor Market, in DISABILITY AND WORK, supra, at 18,21 .

${ }^{55}$ See Samuel Issacharoff, Bearing the Costs, 53 STAN. L. REV. 519, 537 (2000) (reviewing MARk Kelman, Strategy or PRINCIPLE: The ChOICE BetweEn Regulation AND TAXATION (1999)) ("By dismantling the moral cover of antidiscrimination claims, Kelman draws out the redistributive element of statutes like the ADA and then subjects them properly to the difficult choice between regulation and taxation."). Issacharoff and Rosenblum provide a parallel and consistent argument by asserting that the Pregnancy Discrimination Act (PDA) cannot be understood as a leveling device for women of fertile age since they necessarily impose higher costs as a group on employers. See Issacharoff \& Rosenblum, supra note 49, at 2157 (“[P]articular accommodations necessary to allow women to continue their career paths through the period of anticipated fertility means that there will be specific additional costs to employers attendant to female employees."). The same may be said for the position that Issacharoff stakes out on the ADEA and less productive (due to increased salary cost) workers. See Samuel Isaacharoff \& Erica Worth Harris, Is Age Discrimination Really Age Discrimination?: The ADEA's Unnatural Solution, 72 N.Y.U. L. REV. 780, 798-99 (1997) (noting that unlike claims involving race and sex discrimination, an employer defending against a claim of age discrimination will usually have a legitimate cost-based explanation for the employment action).

${ }^{56}$ Issacharoff \& Nelson, supra note 54, at 315-16.

57 See Richard A. EPSTEIN, ForbIDDEN GROUNDS: THE CASE AGAINST EMPLOYMENT DISCRIMINATION LAWS 480-94 (1992) (arguing against the ADA joining the family of antidiscrimination laws, all of which he opposes).

${ }^{58}$ Jill Hasday, for instance, buys into the prevailing paradigm, but from a distinct perspective. Hasday argues that one way in which the ADA abludes from Title VII is that it requires disabled claimants to mitigate their disabilities (and hence identities) as a precondition of receiving statutory protection, whereas group members protected by Title VI are under no such directive. See Jill Elaine Hasday, Mitigation and the Americans with Disabilities Act, $103 \mathrm{MICH}$. L. REV. (forthcoming 2004) (enumerating "an important difference" between the ADA and Title VII). Two quick observations are warranted. First, because the duty to mitigate was imposed by the Supreme Court in Sutton v. United Air Lines, Inc., 527 U.S. 471, 475 (1999), in the absence of any legislative justification the obligation may be more indicative of the Justices' idiosyncratic conception of the ADA rather than that of Congress. See infra text accompanying note 74 (describing the "medical model" of disability). Second, although Hasday is measured in arguing for ("only") a reasonable mitigation standard, I am nevertheless concerned by the implications on disabled individuals' dignity, i.e., that requiring people to mitigate their disabilities could repress the expression of an essential element of 
As an initial matter, Issacharoff and Nelson recognize that a uniform goal of employment discrimination law is to alter how employers select, retain, promote, and compensate their employees. ${ }^{60}$ Title VII, for instance, displays a "smooth interrelation" between antidiscrimination principles and redistributive measures that result from its underlying philosophy of treating similarly situated people similarly. ${ }^{61}$ By contrast, the ADA's accommodation mandate begins with a unique "claim that differently situated people should be treated differently," in that the ADA requires employers to engage disabled workers who, as result of accommodations, are more costly to employ than their nondisabled peers. ${ }^{62}$

They explain, moreover, that Title VII was based on the premise that groups (in their example, African Americans) preferred higher paying, safer jobs, but discriminatory barriers had excluded them from obtaining those jobs. ${ }^{63}$ When Title VII's antidiscrimination command removed those barriers, equality was achieved. ${ }^{64}$ By contrast, $\mathrm{ADA}$ accommodation cases are totally devoid of a subjugation principle analogous to that contained in discrimination "simpliciter"; they argue further that the ADA is exceptional in that it "does not attempt, even as formal matter," to ground itself in an antisubjugation command but is instead driven purely by the goal of shifting resources to the disabled..$^{65}$ Finally, while traditional antidiscrimination provisions seek to proportionately remedy past prejudice, the ADA "eschews this formal equality command" by justifying the provision of ac-

their personal identity, and moreover that these individuals may no longer have $\mathrm{ADA}$ protection post-mitigation. For a somewhat parallel argument in the context of gay/lesbian identity, see Kenji Yoshino, Covering, 111 YALE L.J. 769 (2002).

${ }^{59}$ It is also especially apposite, since he overtly builds upon and cites to Kelman's work. See, e.g., Issacharoff, supra note 55, at 536-37 (agreeing with Kelman's conclusion that the $\mathrm{ADA}$ is redistribution rather than antidiscrimination). Obviously, the same cannot be said for commentators whose work precedes Kelman's. Nevertheless, because those scholars employ the same type of economic analysis that Kelman later clarified and elaborated on in his work, for convenience of proxy I attribute the oeuvre to Kelman.

${ }^{60}$ See Issacharoff \& Nelson, supra note 54, at 309 (stating that employment antidiscrimination laws are implicitly "deeply redistributive" and "seek to alter the outcomes" in the labor market where there is a "belief that ... market preferences are in some deep sense wrong").

${ }^{61}$ Id. at 314-15.

${ }^{62}$ Id. at 315-16.

${ }^{63}$ Id. at 313.

${ }^{64}$ Id. at 313-14.

${ }^{65}$ Id. at 311-14, 357. 
commodation through a determination of whether a given individual has a disability that limits a major life activity. ${ }^{66}$

Two ideas pervade the majority of ADA employment discrimination scholarship: one is that disabled workers are accommodated because they are inherently less capable than nondisabled employees, and a second is that by thereby engendering relatively higher net-cost, providing accommodations to disabled workers brings about a dynamic that goes beyond equality. Taken together, these precepts dissociate the characteristic of disability from the mainstream in a starkly different way than do the characteristics of sex or race. Consequently, canonical scholars maintain that ADA accommodations are redistributive in nature, and are therefore not a true antidiscrimination remedy.

\section{Challenging Where the Canonical Paradigm DIVIDES "SIMPLE DISCRIMINATION" FROM REDISTRIBUTION}

In classifying the $\mathrm{ADA}$ as a redistributive device, the canonical model of employment discrimination creates a false distinction between simple antidiscrimination provisions and redistributive measures. Erroneous assumptions and arguments similar to those once applied to other protected groups, but now discarded, support this distinction. In addition, as a whole, canonical scholarship fails to acknowledge the place of disabled people as the latest group of empowered, biologically atypical workers.

\section{A. Underlying Misconceptions About Accommodation Costs}

A central flaw undermines the nexus where canonical scholarship divides simple discrimination from redistribution when assessing ADA accommodations. This is the baseline assumption that accommodation costs are internally engendered by the disabled person's inherent lower capability, rather than externally caused by social conditions.

\section{The Origin of Accommodation Costs}

As an initial matter, it is empirically uncertain to what extent accommodated workers with disabilities are less net-productive than non-accommodated workers because their accommodation represents

Id. at 317 . 
an additional input cost. ${ }^{67}$ This is a subject which $\mathrm{I}$ have addressed at length elsewhere. ${ }^{68}$ Moreover, to engage the strongest argument put forth by the received wisdom, this Article addresses instances where accommodating disabled workers is in fact costlier than hiring unaccommodated workers. ${ }^{69}$

In assessing the $\mathrm{ADA}$, the canonical perspective assumes that accommodation costs are endogenously engendered by the disabled person's biological inability, rather than exogenously caused by social conditions. Adherence to this precept is logically necessary to conclude that deviations from existing labor market practices, in this case the ADA-compelled accommodations, push the market's balance beyond an equilibrium. Thus the canonical paradigm uses as its initial baseline a status quo that has already excluded disabled participation in the workplace, as opposed to one which evaluates whether exclusion of disabled workers is necessary. Because these workplace inequalities are integrated into the canonical framework, any deviations from the status quo are perceived as bringing about more than equality. $^{70}$

${ }^{67}$ In certain-some would even argue most-circumstances, this will be true. Human variation allows for a number of different and plausible scenarios. The point, though, is that here only one conception of disabled workers is engaged. Thus, the canonical commentators do not include the possibility that accommodated employees with disabilities can be hyper-productive, such that even with the cost of accommodation, their net profit margin is equal to or greater than that of the average nonaccommodated worker. At the same time, these authors also do not assume that disabled workers are per se less productive beyond the cost of accommodations. This makes for an evenhanded, if somewhat unsatisfying, analysis. See, e.g., Michael Ashley Stein, Labor Markets, Rationality, and Workers with Disabilities, 21 BERKELEY J. EMP. \& LAB. L. 314, 316-28 (2000) (criticizing the assumption that accommodations have higher costs than benefits, and presenting alternative measures of productivity).

${ }^{68}$ See Stein, supra note 6, at 103-09 (presenting and critiquing the accommodation cost studies in depth); Stein, supra note 67, at 317-25 (same); Michael Ashley Stein, Empirical Implications of Title I, 85 IOWA L. REV. 1671, 1674-77 (2000) [hereinafter Stein, Empirical Implications] (same).

${ }^{69}$ The point applies equally to other contexts of antidiscrimination, where an empirically sustainable category is not utilized because the observable fact is itself the byproduct of a discriminatory practice. See generally FredERICK SCHAUER, Profiles, PROBABILITIES, AND STEREOTYPES (2003) (arguing for the prevalence and benefit of classifications); Michael Ashley Stein, Generalizing Disability, $102 \mathrm{MICH}$. L. REV. 1373 (2004) (noting that disability ought also to be considered within the group of unused classifications).

${ }_{70}$ My argument parallels the one which Owen Fiss made against rational discrimination in the racial context, namely, that the biological differences that rationalize the discrimination are a by-product of previous irrational discrimination. See Owen M. Fiss, A Theory of Fair Employment Laws, 38 U. CHI. L. REV. 235, 260 (1971) ("[F]ailure to respond to efficiency-based uses of race may have the effect of 'honoring' or 'legitimat- 
In contrast to the canonical perspective of inherent limitations restricting disabled participation, scholars from the disability studies movement ${ }^{71}$ argue for a "social" or "minority" model of disability. According to this framework, the physical environment and the attitudes it reflects play a controlling (if not central) role in creating what society terms "disability." Thus, factors exogenous to a person's own impairments determine how much she can function in society. ${ }^{73}$ This theory is in stark contrast to the "medical model" of disability which, informing the canonical perspective, views a disabled person's limitations as naturally (and thus, properly) excluding her from the mainstream. ${ }^{74}$

ing' racial discrimination that cannot be so justified and that ultimately makes a restriction on blacks conducive to short-run efficiency."). For an alternative application of some of Fiss's arguments to intentional disability-based discrimination, see Samuel R. Bagenstos, The Supreme Court, the Americans with Disabilities Act, and Rational Discrimination, 55 Al.A. L. REV. 923, 947 (2004) (arguing that an acceptance of the view that disability discrimination is rational requires acceptance of the rationality of racial discrimination as well).

${ }^{71}$ Disability studies is an academic discipline analogous to that of critical race or feminist theory, with dedicated university departments. Gary L. Albrecht et al., Introduction: The Formation of Disability Studies, in HANDBOOK OF DisABILITY STUDIES 2-5 (Gary L. Albrecht et al. eds., 2001) [hereinafter HANDBOOK]. For discussion of how the discipline has moved from the margin to the mainstream, see SIMI LINTON, Claiming Disability: KNOWledge and Identity 3 (1998); Catherine J. Kudlick, Disability History: Why We Need Another "Other," 108 AM. HIST. REV. 763, 770 (2003).

${ }^{72}$ As explained by one of the originators of the theory, the minority rights model is based on three major postulates: (1) the primary problems faced by disabled persons stem from social attitudes rather than from functional limitations; (2) all facets of the man-made environment are shaped or molded by public policy; and (3) in a democratic society, public policies represent prevailing public attitudes and values.

Harlan Hahn, Feminist Perspectives, Disability, Sexuality, and Law: New Issues and Agendas, 4 S. CAL. REV. L. \& WOMEN's STUD. 97, 105 (1994) (footnotes omitted); see also id. at 101 ("[D] isability is attributed primarily to a disabling environment instead of bodily defects or deficiencies.").

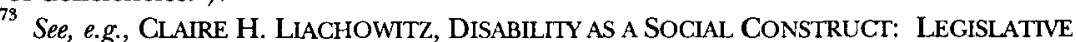
ROOTs 1-16 (1988) (tracing the legal classification of disability as an outgrowth of the public's opinion that physical disability confers social inferiority); SUSAN WENDELL,

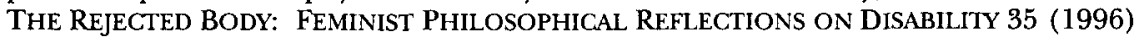
(noting the difficulty in marking "the distinction between the biological reality of a disability and the social construction of a disability"); Ron Amundson, Disability, Handicap, and the Environment, 23 J. SOC. PHIL. 105, 110 (1992) (stating that "a handicap results from the interaction between a disability and an environment"); Richard $\mathrm{K}$. Scotch, Making Change: The ADA as an Instrument of Social Reform, in EXPLORING IMPLICATIONS, supra note 21 , at 275,275 ("[The] social model of disability ... conceptualizes disability as a social construction that is the result of interaction between physical or mental impairment and the social environment.").

${ }^{74}$ See Kenny Fries, Introduction, in STARING BACK: THE DISABILITY EXPERIENCE 
One of the earliest contributions to the development of the social model of disability, before there even was a disability studies movement, was made by Jacobus tenBroek. ${ }^{75}$ TenBroek argued that disabled people's own physical limitations had far less to do with their ability to participate in society than did "a variety of considerations related to public attitudes," many of which were "quite erroneous and misconceived. ${ }^{76}$ TenBroek's theory, expressed in the context of tort law standards, ${ }^{77}$ has been utilized by scholars from other disciplines, especially by feminist scholars who challenge where the line has been drawn between equality and more-than-equality when applied to groups of biologically atypical individuals. ${ }^{78}$

FROM THE INSIDE OUT 6-7 (Kenny Fries ed., 1997) (noting that "this view of disability... puts the blame squarely on the individual"); LIACHOWTIZ, supra note 73, at 11 (averring that the "medical/pathological paradigm" of disability stigmatizes the disabled by conditioning their inclusion only "on the terms of the ablebodied majority" (emphasis omitted)).

Among his many accomplishments, tenBroek was a professor of political science at the University of California, Berkeley, and also founded the National Federation of the Blind, an organization over which he presided for twenty-three years. FRED PELKA, THE ABC-CLIO COMPANION TO THE DISABILITY RIGHTS MOVEMENT 303 (1999).

${ }^{76}$ Jacobus tenBroek, The Right to Live in the World: The Disabled in the Law of Torts, 54 CAL. L. REv. 841, 842 (1966).

${ }_{77}$ In the article, tenBrock demonstrated how people with disabilities were historically held to higher duties of care with respect to the law of torts. Underlying this divergence was the theory that the operative "reasonable and objective" standard could not be uniformly applied to biologically impaired people, for they were inherently less able to engage in social functions. As a consequence, until the passage of "white cane laws," a blind person who had used neither a cane nor a dog while receiving an injury in the public domain was precluded from recovery on the ground of contributory negligence. This was because, as a matter of law, visually impaired people were required to exercise a higher standard of care than others. Id. at 877-82.

${ }^{78}$ See, e.g., MARTHA MINOW, MAKING ALL THE DIFFERENCE: INCLUSION, EXCLUSION, AND AMERICAN LAW 101-10 (1990) (assessing whether biological differences require different legal treatment); MARTHA C. NUSSBAUM, HIDING FROM HUMANITY: DISGUST, SHAME, AND THE LAW 306 (2004) (noting that "a handicap does not exist simply 'by nature' .... [I] t only becomes a handicap when society treats it in certain ways"). Feminist scholars have long argued that because of analogous environmental considerations, accommodations are a necessary component of sex-based antidiscrimination remedies. See, e.g., Leslie Bender, Sex Discrimination or Gender Inequality?, 57 FORDHAM L. REv. 941, 949-53 (1989) (rejecting the current "male gendered" workplace culture); Herma Hill Kay, Equality and Difference: The Case of Pregnancy, 1 BERKELEY WOMEN'S L.J. 1, 28 (1985) ("The social value of accommodating reproduction and employment opportunities so that women remain free to engage in both activities on an equal basis with men justifies the additional cost."); Deborah L. Rhode, Perspectives on Professional Women, 40 STAN. L. REV. 1163, 1185-93, 1202-07 (1988) (examining constraints on women in the workplace and comparing the options of assimilation or alteration of the workplace culture); Cathy Shuck, Comment, That's It, I Quit: Returning to First Principles in Constructive Discharge Doctrine, 23 BERKELEY J. EMP. \& LAB. 
An eloquent application of the social model of disability to the $\mathrm{ADA}$, and one which rebuts the canonical view of disability-related accommodations as redistributive, is by philosopher and disability rights commentator Anita Silvers. ${ }^{79}$ Silvers argues that being biologically anomalous is only viewed as abnormal because a dominant group has imposed conditions that are most favorable to its own circumstances, rather than because of "any biological mandate or evolutionary triumph." ${ }^{80}$ According to her, the social model of disability traces the source of disabled peoples' relative disadvantage to the existence of a hostile environment that is "artificial and remediable" as opposed to "natural and immutable." Silvers provides an example of disability as a social construct in explaining that from the viewpoint of a person mobilized in a wheelchair, disability is experienced by lack of access to workplaces, educational programs, medical services, and other areas otherwise open to the public. ${ }^{82}$ Since the ADA seeks to remove the subordination of individuals with disabilities, Silvers argues that it is a product of formal and equalizing justice, rather than of redistributive or material justice. ${ }^{83}$ In her view, the ADA is based on notions of for-

L. 401, 403-05 (2002) (examining the doctrine of constructive discharge in sexual harassment cases). Accordingly, Harlan Hahn has noted that the minority rights model "seeks to promote both equal rights and a positive sense of personal and political identity parallel to the second wave of the women's movement." Hahn, Feminist Perspectives, supra note 72, at 98; see also Richard K. Scotch \& Kay Schriner, Disability as Human Variation: Implications for Policy, 549 ANNALS AM. ACAD. POL. \& SOC. SCI. 148, 154-57 (1997) (proposing that the discrimination-focused minority model be supplanted by a model describing disabilities as manifestations of human variation). TenBroek's work is, naturally enough, also frequently cited by those writing in the disability field. See, e.g., Samuel R. Bagenstos, The Americans with Disabilities Act as Risk Regulation, 101 Colum. L. REV. 1479, 1483-89 (2001) (exploring the politics of risk valuation and regulation in the ADA); Jonathan C. Drimmer, Cripples, Overcomers, and Civil Rights: Tracing the Evolution of Federal Legislation and Social Policy for People With Disabilities, 40 UCLA L. REV. 1341, 1344-48 (1993) (criticizing the ADA as codifying the medical-social pathology model of disability, by granting only limited rights of workplace access to the disabled); Mark C. Weber, Disability and The Law of Welfare: A Post-Integrationist Examination, 2000 U. ILL. L. REV. 889, 889, 956 (2000) (examining the law of welfare as it affects disabled persons and arguing for its reform).

${ }_{79}$ Anita Silvers, Formal Justice, in Disability, DIFFERENCE, DISCRIMINATION: Perspectives on JUSTICE IN BIOETHics AND Public POLICY 13 (Anita Silvers et al. eds., 1998) (advocating full social access and participation of people with disabilities).

${ }^{80} I d$. at 73. Thus "[i]f the majority of people, instead of just a few, wheeled rather than walked, graceful spiral ramps instead of jarringly angular staircases would connect lower to upper floors of buildings." Id. at 74.

${ }^{81}$ Id. at 75 .

${ }^{82} I d$. at 74 .

${ }^{83}$ See id. at 119-26 (analyzing the theory behind the ADA and its impact on disabled persons). 
mal justice due to its acknowledgment that equal access to goods and opportunity is not a special benefit. ${ }^{84}$ Rather, the statute sanctions intervention into existing social constructs by questioning an environment that artificially disadvantages people with disabilities. ${ }^{85}$ Consequently, Silvers concludes that it is erroneous to characterize the provision of a reasonable accommodation "as advantaging the individual for whom it is made."

I generally agree with, and build on, the disability studies perspective in arguing that the ADA is an appropriate antidiscrimination device because it remedies avoidable exclusion. Nevertheless, the strongest version of the argument, as expressed by Silvers, also has limitations. At present, some barriers are both natural and necessary. There are some workers with disabilities whose impairments cannot be ameliorated through reasonable (or even extra-reasonable) accommodations. Thus, not all exclusion from the workplace is artificial. $^{87}$ By the same token, accommodations can also enable the occupational participation of naturally excluded individuals with disabilities. I use the term artificial to mean avoidable, because it is either (a) arbitrary and easily remedied, or (b) natural but nonetheless can be remedied through a manageable cost. I therefore argue below that $\mathrm{ADA}$ accommodations (which are limited by their reasonable and proportionate expense), appropriately remedy historical exclusion. ${ }^{88}$ Regardless of where one defines the boundaries of artificiality, what is crucial to the plausibility of an assertion of artificial exclusion, whether framed in terms of the social model of disability or otherwise, ${ }^{89}$

${ }^{84}$ Id. at 120 . Silvers uses the example that equal opportunity to use the stairs does not equate to equal opportunity to attend a program that takes place at the top of those stairs. Formal justice requires equal access to the program, although people walking and using wheelchairs may take different routes. Id. at 127.

${ }^{85}$ See id. at 124 ("The ADA facilitates formal intervention into the rules of social games by permitting questions to be raised about the justification of whatever disparately disadvantaging impact they may have.").

${ }_{86}$ Id. at 132.

${ }^{87}$ Two points bear noting. First, that with continuing technological and scientific development, a variety of disabilities will be mitigated. Thus, both the notion of what disability means and the ability to accommodate individuals within the category are fluid. Second, that the term "artificial" conveys both a descriptive and a normative element, and so must be used cautiously.

${ }^{88}$ For an in-depth discussion, see Stein, supra note 6, at 90-109; see also infra Part III.B.1 (describing the ADA's "reasonable cost" limitation).

${ }^{89}$ Madhavi Sunder makes a parallel argument in the context of women's rights. See Madhavi Sunder, Cultural Dissent, 54 STAN. L. REV. 495, 503 (2001) [hereinafter Sunder, Cultural Dissent] (arguing against the reinforcement of repressive cultural norms); Madhavi Sunder, Piercing the Veil, 112 YaLE L.J. 1399, 1403 (2003) (maintain- 
is whether as a general matter those omissions are viewed as inevitable or avoidable. ${ }^{90}$

Altering an instantiated "nomos," meaning a socially accepted definition of the normative universe, ${ }^{91}$ requires success in asserting "the politics of recognition," and as such is a difficult task. ${ }^{92}$ Law's force is largely grounded in its power to convince people that the single option chosen from among many is the only legitimate one, and then to reinforce the illusion of that validity. ${ }^{93}$ The disability studies assertion that artificial barriers to inclusion are socially constructed, and hence malleable, parallels assertions made concerning other groups on the basis of race,,$^{94}$ sex, ${ }^{95}$ and sexual orientation. ${ }^{96}$ Nonethe-

ing that the legal system ought to resist fundamentalist religious groups who enforce hegemonic and stifling norms against women).

${ }_{90}$ See Paula E. Berg, Ill/Legal: Interrogating the Meaning and Function of the Category of Disability in Antidiscrimination Law, 18 YALE L. \& POL'Y REV. 1, 3 (1999) (suggesting that more attention needs to be paid to which "epistemological assumptions about the nature of disability underlie judicial construction of a highly restrictive category"). Carrying the point of exclusion even further, historian Deborah Stone argues that " $[t]$ he very act of defining a disability category determines what is expected of the nondisabled-what injuries, diseases, incapacities, and problems they will be expected to tolerate in their normal working lives." Deborah A. STONe, ThE Disabled STATE 4 (1984).

${ }^{91}$ See Robert M. Cover, Foreword: Nomos and Narrative, 97 HARV. L. REV. 4, 4 (1983) ("No set of legal institutions or prescriptions exists apart from the narratives that locate it and give it meaning.").

${ }_{92}$ Charles Taylor, The Politics of Recognition, in Multiculturalism 25, 25 (Amy Gutmann ed., 1994). For example, Madhavi Sunder describes the way in which individuals within a culture challenge the empowered hegemony to modernize or broaden its perspective. She also points out that as society and cultural association diversifies, law rather than culture comes to regulate acceptable limits of difference. Thus, it becomes more difficult to challenge repressive normative communities as they become more instantiated. See Sunder, Cultural Dissent, supra note 89, at 509-23.

${ }^{93}$ See Robert W. Gordon, Critical Legal Histories, 36 STAN. L. REv. 57, 109 (1984) ("[T] he power exerted by a legal regime consists [substantially] ... in its capacity to persuade people that the world described in its images and categories is the only alternative world in which a sane person would want to live."); see also ALAN HYDE, BODIES OF LAW 231 (1997) ("Law veils its own power ... by pretending to find what it in fact makes itself.”); Richard Delgado, Norms and Normal Science: Toward a Critique of Normativity in Legal Thought, 139 U. PA. L. Rev. 933, 943 (1991) (pointing out that sometimes it is difficult to break with assigned norms because "[w]e assign the things their weights, and then pretend that it is the scale that gives us the information").

See, e.g., Kimberlé Williams Crenshaw, Race, Reform, and Retrenchment: Transformation and Legitimation in Antidiscrimination Law, 101 HARV. L. REV. 1331, 1376-87 (1988) (noting the pervasive and racist nature of seemingly neutral legal norms); Alan David Freeman, Legitimizing Racial Discrimination Through Antidiscrimination Law: A Critical Review of Supreme Court Doctrine, 62 MINN. L. REV. 1049, 1054 (1978) (noting that antidiscrimination theory "views racial discrimination not as a social phenomenon, but merely as the misguided conduct of particular actors .... [T] he task of anti- 
less, as Jerry Mashaw noted more than a decade ago, " $t]$ he notion that there has been some systematic ... social practice of discriminating against the disabled will strike most people as simply untrue. ${ }^{97}$

\section{Inherent Inability and Fixed Identity}

Because the canonical view of ADA accommodations is that they are impelled by inherent inability rather than social construction, these scholars equate the biological atypicalities associated with "disability" with an inherent and fixed limitation. ${ }^{98}$

Perhaps the most damaging manifestation of this concept, expressed in sociological terms, is that people with disabilities are viewed as "inauthentic workers." ${ }^{\text {"99 }}$ Set against the backdrop of public policies that presume people with disabilities can and should receive public assistance rather than engage in employment, this perception justifies the disadvantaged socioeconomic position of workers with disabilities who are employed in lower paying or less demanding positions. ${ }^{100}$ In

discrimination law is to separate from the masses of society those blameworthy individuals who are violating the otherwise shared norm").

${ }_{95}$ See Mary F. Radford, Sex Stereotyping and the Promotion of Women to Positions of Power, 41 HASTINGS L.J. 471, 489-90 (1990) (noting that "[s] ex stereotyping in the workplace is embedded in a complicated matrix of interlocking beliefs" based on socially-constructed definitions of "male" and "female").

${ }^{96}$ See JANET E. Halley, Don'T: A Reader's Guide to the Military's anti-Gay POLICY 17 (1999) ("How long will we use the coercive powers of the state to define, construct, and populate heterosexuality as a morally endorsable human and social class of persons?").

${ }_{97}$ Jerry L. Mashaw, Against First Principles, 31 SAN DIEGO L. REv. 211, 219-20 (1994).

${ }^{98}$ But see Oliver SaCks, An ANThropologist on Mars: SEven Paradoxical TALES 77-107 (1995) (describing the life of a surgeon with Tourette's Syndrome, a disability which might be thought of as disqualifying). Similarly, the U.S. Commission on Civil Rights noted that people with disabilities undergo a "spread effect" in which ablebodied people assume that the existence of one impairment implies general disability. For example, people speak more loudly or slowly to a person who is visually impaired. Christopher G. Pell \& ROBERT L. BURGdorf, U.S. COMM'N ON CIVIL RIGHTS, ACCOMMODATING THE SPECTRUM OF INDIVIDUAL ABILITIES 25 (1983); see also WENDELL, supra note 73, at 4 ("People without disabilities tend to assume that a person with a disability is unable to participate in most of the life activities they consider important.").

${ }^{99}$ I draw this phrase, as well as inspiration, from the very powerful Vicki Schultz, Life's Work, 100 COLUM. L. REv. 1881, 1892 (2000). See also Harlan Hahn, Advertising the Acceptably Employable Image: Disability and Capitalism, 15 POL'Y STUD. J. 551, 551 (1987) (averring that the dominant image projected by employers seeking to develop an "industrial reserve army" was one that excluded the participation of workers with disabilities).

${ }^{100}$ Defining someone as disabled under the Social Security system "incorporates 
jurisprudential terms, this can be expressed as viewing people with disabilities as not being similarly situated to those without disabilities; in conventional terms, it means believing that the disabled, despite analogies to other biologically atypical groups, nonetheless remain "different" in an inferior sense. ${ }^{101}$

common expectations and shared values about what infirmities a person ought not to have to bear and keep working." Lance Liebman, The Definition of Disability in Social Security and Supplemental Security Income: Drawing the Bounds of Social Welfare Estates, 89 HARV. L. ReV. 833, 853 (1976); see also Richard V. Burkhauser, Post-ADA: Are People with Disabilities Expected to Work?, 549 ANNALS AM. ACAD. POL. \& SOC. SCI. 71, 75 (1997) (questioning whether the ADA was designed in a fashion that allowed the disabled the choice, let alone the support mechanisms, of working); Matthew Diller, Dissonant Disability Policies: The Tensions Between the Americans with Disabilities Act and Federal Disability Benefit Programs, 76 TEX. L. REV. 1003, 1064 (1998) ("SSA's disability determinations represent social judgments about who should be expected to work, rather than findings of medical fact."); Matthew Diller, Entitlement and Exclusion: The Role of Disability in the Social Welfare System, 44 UCLA L. REv. 361, 386 (1996) ("[D]isability status is an indication that an individual is deemed excused from the work force, rather than a judgment that the individual is actually incapable of working productively."); Harlan Hahn, Accommodations and the ADA: Unreasonable Bias or Biased Reasoning?, 21 BERKELEY J. EMP. \& LAB. L. 166, 169-70 (2000) (contending that social security eligibility rules and workplace discrimination jointly deter people with disabilities from seeking employment); Anita Silvers \& Michael Ashley Stein, Disability, Equal Protection, and the Supreme Court: Standing at the Crossroads of Progressive and Retrogressive Logic in Constitutional Classification, 35 MICH. J.L. REFORM 81, 84 (2002) [hereinafter Silvers \& Stein, Standing at the Crossroads] (describing "welfarist" policies which presume people with disabilities will not engage in employment opportunity); Anita Silvers \& Michael Ashley Stein, From Plessy (1896) and Goesart (1948) to Cleburne (1985) and Garrett (2001): A Chill Wind From the Past Blows Equal Protection Away, in BACKLASH AGAINST THE ADA: REINTERPRETING DISABILITY RIGHTS 221, 243 (Linda Hamilton Krieger ed., 2003) [hereinafter Silvers \& Stein, Chill Wind] (describing how Congress "imported into the ADA's definition of disability the Rehabilitation Act's welfarist conception of the nature of the disability category").

In describing the parallel position of women, Schultz points out the odd position of Nobel Prize-winning economist Gary Becker, who maintains that women are occupationally disadvantaged because of their "comparative advantage" at child care and housework. Schultz, supra note 99, at 1893-98; see also GARY S. BECKER, A TREATISE ON THE FAMILY 22 (1981) (arguing that an efficient allocation of resources "would mainly allocate the time of women to the household sector"); VicTOR R. FUCHS, WOMEN'S QUEST FOR ECONOMIC EQUALITY 60 (1988) (opining that women's wage disparity is the result of "women who devote a great deal of time and energy to childcare and associated housework [and] are often less able to devote maximum effort to market work"); Gary S. Becker, Human Capital, Effort, and the Sexual Division of Labor, 3 J. LAB. ECON. S33, S52 (1985) (“[M]arried women seek occupations and jobs that are less effort intensive and otherwise are more compatible with the demands of their home responsibilities.").

${ }^{101}$ See MINOW, supra note 78, at 106, 157-59 (observing that the use of categorization in law and public policy often "treats differences as intrinsic to the person or institution, as functions of internal competencies and abilities"). 
Accordingly, such a perspective views providing accommodations as a form of affirmative action or "special rights."102 This is a position that only a few commentators take explicitly, ${ }^{103}$ but which is the logical extension of the canonical position equating the ADA with redistribution rather than as a remedy for simple discrimination. Although I would not object to the provision of affirmative action in addition to rigorous $\mathrm{ADA}$ compliance, associating disability employment rights strictly with affirmative action links the provision of accommodations to political will rather than to equality jurisprudence. Moreover, it links disability rights with a politically endangered position that has been the target of a strong backlash. ${ }^{104}$ Despite the Supreme Court's limited approbation of particular policies in the education area, ${ }^{105} \mathrm{re}$ sistance to affirmative action has formed the heart of what Jed Rubenfeld describes as the "Anti-Antidiscrimination Agenda." 106 And, as Peter Rubin has aptly noted, labeling rights as "special" rather than as antidiscrimination is an invitation for decision makers to inject their

102 See Peter J. Rubin, Equal Rights, Special Rights, and the Nature of Antidiscrimination Law, 97 MICH. L. REV. 564, 564-65 (1998) (fearing that "courts may conflate antidiscrimination laws that essentially mirror the Constitution's own command with affirmative action provisions whose constitutionality can be determined under current law only after they have been subjected to searching judicial scrutiny").

${ }^{109}$ But see SAMUEl LeITER \& William M. LeITER, AFFIRMATIVE ACTION IN ANTIDISCRIMINATION LAW AND POLICY: AN OVERVIEW AND SYNTHESIS 53 (2002) (“ $[S]$ ystematic bias against protected groups requires a cure that goes "beyond compensation to individuals for direct individual injury.'”); Befort \& Thomas, supra note 54 , at 75 (arguing that because reasonable accommodation "is a concept alien to most antidiscrimination claims brought under Title VII," it is, "in essence, a form of affirmative action for disabled individuals"); Karlan \& Rutherglen, supra note 54, at 3 (claiming that disabled workers seeking accommodations can "insist upon discrimination in their favor"); Rosen, supra note 54, at 21 (asserting that the ADA "require[s] firms to treat unequal people equally, thus discriminating in favor of the disabled").

${ }^{104}$ The existence of a backlash against disability rights was explored from a number of different angles by Marta Russell, in Backlash, the Political Economy, and Structural Exclusion, 21 BERKELEY J. EMP. \& LAB. L. 335 (2000). Russell asserts that "capitalist opposition" to the ADA has "promoted the backlash among groups of workers who have become fearful that their own interests are in jeopardy as a result of the Act's enforcement powers." Id. at 336. Stephen Percy has noted that critics of the ADA have characterized the Act as an unacceptable "instance of expansive regulatory mandates on the private sector." Stephen L. Percy, Administrative Remedies and Legal Disputes: Evidence on Key Controversies Underlying Implementation of the Americans with Disabilities Act, 21 BERKELEY J. EMP. \& LAB. L. 413, 433 (2000).

${ }^{105}$ See Grutter v. Bollinger, 123 S. Ct. 2325, 2342 (2003) (concluding that a law school's "compelling interest in a diverse student body" justified a "narrowly tailored" affirmative action policy); see also Pauline T. Kim, The Colorblind Lottery, 72 FORDHAM L. REv. 9,9 (2003) (noting that the Supreme Court has "sent mixed messages" in recent decisions on affirmative action in education).

${ }^{106}$ Jed Rubenfeld, The Anti-Antidiscrimination Agenda, 111 YALE L.J. 1141 (2002). 
own normative judgments about the protected class's character, and so "introduce into their analyses their own stereotyped ways of thinking." 107

This perspective of disability rights being "special" and more of a piece with affirmative action than with equality fits squarely with the medical model of disability, and is in direct opposition to the social or minority model of disability. ${ }^{108}$ The medical framework posits that disability is a biological infirmity to be "cur[ed]" or fixed by doctors and rehabilitation professionals. ${ }^{109}$ Although academic commentators holding fast to the canonical perspective do so from a medical model of disability, to my knowledge only Richard Epstein has openly expressed the idea that people with disabilities ought to be treated with pity. ${ }^{110}$ On the other hand, recent Supreme Court opinions provide several examples of such sentiment. ${ }^{\text {III }}$ Within the employment context, Justice Kennedy's Garrett concurrence is perhaps the most obvious example of viewing ADA claims as exceeding equality. ${ }^{112}$ Instead

${ }^{107}$ Rubin, supra note 102, at 567; see also Glenn C. Loury, Why Should We Care About Group Inequality?, 5 SOC. PHIL. \& POL'Y 249, 263 (1987) ("[R]eliance on affirmative action... can have a decidedly negative impact on the esteem of the [beneficiary] groups, because it can lead to the general presumption that members of the beneficiary groups would not be able to qualify for such positions without the help of special preference.").

${ }^{108}$ Unintended, but nonetheless ironic, is that many people with disabilities bridle at the term "special," a euphemism associated with "special needs" schools and other exclusionary experiences, as well as an overly polite term for invoking sympathy. See, e.g., Mary Johnson, Sticks and Stones: The Language of Disability, in THE DISABLED, THE MEDIA, AND THE INFORMATION AGE 25, 30-34 (Jack A. Nelson ed., 1994) (presenting arguments that euphemisms such as "special" or "physically challenged" mask deeply prejudicial and adverse actions against the disabled).

${ }^{109}$ See Gareth Williams, Theorizing Disability, in HANDBOOK, supra note 71, at 123-44 (cataloging the ways in which people with disabilities have historically been viewed); Drimmer, supra note 78, at 1345-59 (describing the moral, medical, social pathology, and civil rights models of disability).

110 "Having a disability is the source of an enormous level of personal loss" leading to "sympathies" that "tug knowingly at the heartstrings" and inspire "charitable giving and charitable services." EPSTEIN, supra note 57, at 486. Although I disagree with Epstein on this point, as well as many others, I admire his honesty.

${ }^{111}$ An alternative tack is taken by political scientist Ruth O'Brien, who argues that modern disability employment practices are influenced by vocational rehabilitation policies that only integrate disabled workers who have fully adapted themselves to the workplace. One consequence of this normative schema, which $O^{\prime} B$ rien avers influences judicial attitudes towards people with disabilities, is Supreme Court resistance to disability rights, and especially the ADA's employment provisions. RUTH O'BRIEN, CRIPPLED JUSTICE: THE HistoRY OF MODERN DISABILITY POLICY IN THE WORKPLACE (2001).

${ }^{12}$ See Bd. of Trustees v. Garrett, 531 U.S. 356, 375 (2001) (Kennedy, J., concurring) (" $[T]$ he accusation is based not on hostility but instead on the failure to act or 
of evaluating the circumstances that caused the suit, Justice Kennedy characterized the issue as one that invoked a wrestling match between "our own human instincts" on the one hand, ${ }^{113}$ and "the better angels of our nature" that sympathize for "those disadvantaged by mental or physical impairments" on the other. ${ }^{114}$ Also notable in Garrett was the Chief Justice condoning state discrimination in employment as a legitimate activity because "hardheartedly" refusing to make "allowance[s]" or "special accommodations" for disabled workers was entirely rational. ${ }^{115}$

The canonical treatment of ADA accommodations views the source of whatever extra cost their provision engenders as arising from the endogenous, inherent inability of the disabled, rather than through the exogenous, constructed social environment. In doing so, the received wisdom is that workers with disabilities belong to a fixed category of individuals with immutably lower ability.

\section{B. The Lessons of History}

Similar to arguments now used in canonical scholarship to distinguish ADA accommodations from traditional antidiscrimination claims are the arguments made against equalizing measures for women and for African Americans. ${ }^{116}$ Accordingly, the first subsection

the omission to remedy.").

${ }^{113}$ Id. at 375 .

${ }^{114} I d$. at 376 .

${ }^{115}$ Id. at 367-69. (Rehnquist, C.J.) Also, in PGA Tour, Inc. v. Martin, 532 U.S. 661 (2001), a Title III public accommodation decision, the Court upheld the reasonable accommodation request of a well-known golf player with a mobility impairment to use a golf cart rather than walk during a tournament. Id. Justice Scalia's dissent testifies to the persistence of the medical model by characterizing Martin's claim as one for "benevolent compassion" that would require the Court to undertake "misty-eyed" decisions. Id. at 691, 704 (Scalia, J., dissenting).

${ }^{116}$ See, e.g., STEPHEN JAY GOULD, THE MISMEASURe OF MAN 30-72 (1981) (describing the use of scientific thought to mold thinking about the intellectual inferiority of blacks); John S. Haller, JR. \& Robin M. Haller, The Physician and Sexuality in VICTORIAN AMERICA 51 (1974) (describing the common notion that "the grown-up Negro partakes, as regards his intellectual faculties, of the nature of the child"); Devon W. Carbado \& Mitu Gulati, Working Identity, 85 CoRNELL L. REV. 1259, 1307 (2000) (concluding that outsiders groups-traditionally women and minorities-have, "to the extent they wish to survive in the workplace ... [had to] do extra work to make themselves palatable and their insider employers comfortable"); Kenneth L. Karst, Myths of Identity: Individual and Group Portraits of Race and Sexual Orientation, 43 UCLA L. REV. 263, 270 (1995) (noting that in the past "science reinforced white supremacy"); see also Plessy v. Ferguson, 163 U.S. 537, 551 (1896) (upholding the legality of racial segregation on the ground that "[1] egislation is powerless to ... abolish distinctions based upon physical differences"); Id. at 562 (Harlan, J., dissenting) (bridling at how the ma- 
describes the workplace experiences of women, and the second describes the categorization of African Americans on the ground of scientific and medical "reality." The last subsection demonstrates how civil rights measures always engender cost.

\section{The Inherent Inability of Women}

For much of the nineteenth and twentieth centuries, social convention held that women were physically less capable than men. Under the prevailing norms of that time, the sexes were believed to occupy different spheres. ${ }^{117}$ People believed that women's physical makeup, in particular their bodily functions relating to reproduction, were demonstrated signs of inherent frailty. ${ }^{118}$ Physicians insisted that biological characteristics only permitted women to pursue certain activities outside of the home. ${ }^{119}$ (Male) doctors warned (male) legislators that women seeking to compete in a man's world were a serious threat to their own health. ${ }^{120}$ This opinion was not advanced as the result of empirically verified observation, but rather as an obvious and understood physiological actuality.

Legislators accepted the social convention that women were physically less capable than men, and courts enforced it. The Supreme Court, composed of the same Justices who three years earlier

jority opinion reflected the notion that "the integrity of the white race may be corrupted" by contact with black people); Crenshaw, supra note 94, at 1373 (asserting that African Americans were traditionally misperceived by whites as immoral). A seminal treatment of the historical subjugation of African Americans is A. LEON HIGGINBOTHAM, JR., IN THE MATTER OF COLOR: RACE AND THE AMERICAN LEGAL PROCESS: THE COLONLAL PERIOD (1978).

${ }^{117}$ For a general overview, see CYNTHIA ELLEN HARRISON, ON ACCOUNT OF SEX: The PoltTics of Women's Issues, 1945-1968 (1988); Christine A. Lunardini, WOMEN'S RIGHTS (1996); SANDRA F. VANBURKLEO, BELONGING TO THE WORLD: WOMEN'S RIGHTS AND AMERICAN CONSTITUTIONAL CULTURE (2001).

${ }^{118}$ See BARBARA EHRENREICH \& DEIRDRE ENGLISH, FOR HER OWN GoOD: 150 YEARS OF THE EXPERTS' ADVICE TO WOMEN 134 (1979) ("Doctors had established that women are sick, that this sickness is innate, and stems from the very possession of a uterus and ovaries.").

119 "The general theory which guided the doctors' practice as well as their public pronouncements was that women were, by nature, weak, dependent, and diseased." Id. at 102-03.

${ }^{120}$ See, e.g., id., at 110 ("In fact, the theories which guide the doctor's practice from the late nineteenth century to the early twentieth century held that woman's normal state was to be sick."); Sheila M. Rothman, WOMAN's Proper Place: A History of Changing Ideals and Practices, 1870 to the Present $23-25$ (1978) (describing the perceived dictatorship of a woman's body over her daily activities). 
had (infamously) ${ }^{121}$ upheld broad freedom of contract in Lochner $v$. New York, ${ }^{122}$ held in Muller $v$. Oregon ${ }^{129}$ that an Oregon statute restricting the hours of women's employment to ten hours per day was a valid exercise of the state's police power. ${ }^{124}$ It predicated this divergence on the notion that since "healthy mothers are essential to vigorous offspring," women's physical well being was "an object of public interest and care." ${ }^{125}$ Without citing any sound evidence of deleterious effects that working more than ten hours a day at a laundry would have on women, the Court stated that the restriction was warranted by "woman's physical structure and the performance of maternal functions" which "place her at a disadvantage" relative to man with whom "she is not an equal competitor." Similar restrictions on the hours women could work, the wages they could earn, and the occupations they could hold were subsequently upheld in a number of other cases. ${ }^{127}$ Each of these decisions relied on the broadly accepted, 'but

${ }^{121}$ See, e.g., Barry Friedman, The History of the Countermajoritarian Difficulty, Part Three: The Lessons of Lochner, 76 N.Y.U. L. REV. 1383, 1383 (2001) (rebuffing revisionist attempts at demonstrating the decision's legitimacy); David A. Strauss, Why was Lochner Wrong?, 70 U. CHI. L. REV. 373, 373 (2003) (opining that Lochner "would probably win the prize ... for the most widely reviled decision of the last hundred years."). But see RICHARD A. EPSTEIN, TAKINGS: PRIVATE PROPERTY AND THE POWER OF EMINENT DOMAIN 128-29 (1985) (defending Lochner from a libertarian perspective); PAUl KENS, LOCHNER V. NEW YORK: ECONOMIC REgULATION ON TRIAL 2-5 (1998) (analyzing the decision within the historical context of conflicting political ideologies and an incipient labor movement); David E. Bernstein, Lochner's Legacy's Legacy, 82 TEX. L. REV. 1, 63-64 (2003) (same).

${ }^{122} 198$ U.S. 45, $56(1905)$ (holding that a state labor law that limited the hours worked by bakery "employees" was an "unreasonable, unnecessary and arbitrary interference" with an individual's personal liberty to contract for his own services).

${ }^{123} 208$ U.S. 412 (1908). See generally Anne C. Dailey, Lochner for Women, 74 TEX. L. REv. 1217 (1996) (comparing the differential gender implications of Muller with those of Lochner).

${ }^{124}$ Muller, 208 U.S. at 423 . The statute restricted the employment of any "female" in "any mechanical establishment, or factory, or laundry" for more than ten hours of any twenty-four-hour cycle. Id. at 416 .

${ }^{125}$ Id. at 421.

${ }^{126}$ Id. What the Court did cite, however, was Louis Brandeis's brief containing a series of reports, both domestic and international, that reiterated the social convention "that long hours are dangerous for women, primarily because of their special physical organization." Id. at 419 n.1. I thank Catherine Wells for this observation.

${ }^{127}$ See, e.g., Judith Olans Brown et al., The Mythogenesis of Gender: Judicial Images of Women in Paid and Unpaid Labor, 6 UCLA WOMEN's L.J. 457, 537-39 (1996) (describing how traditional stereotypes about women have informed judicial decision making, e.g., in Jefferson v. Hackney, 406 U.S. 535 (1972), King v. Smith, 392 U.S. 309 (1968) and New York Dep't of Social Services v. Dublino, 413 U.S. 405 (1973)). 
factually unsubstantiated, ground that women were relatively frail when compared to men.

This framework for justifying the exclusion of women from occupational opportunity on the basis of unfounded stereotypical assumptions changed dramatically following the passage of the Civil Rights Act of $1964 .{ }^{129}$ Previously held notions that automatically assigned women to certain occupational roles, and precluded their participation in others based on stereotypes surrounding their bodily deficiency, were replaced by a standard that examined the role of social construction and which therefore placed a heavy burden of proof upon employers seeking their exclusion. ${ }^{130}$ As a result, the Supreme Court has evolved its sex-based jurisprudence from one that automatically assumed that women were inherently less capable then men, and therefore justifiably excluded from workplace opportunity, to one where the Justices evaluate claims of physical difference and equality in the light of social convention. ${ }^{131}$

Thus, the historical exclusion of women from employment opportunity parallels the current treatment of workers with disabilities. In both instances, the physical ability of a group was presumed to be less than that of the mainstream due to social convention. This is a perception that continues to prevail with regard to disabled workers.

${ }^{128}$ See generally JULIE NOVkOV, CONSTITUTING WORKERS, PROTECTING WOMEN: Gender, LAW, AND LABOR IN THE Progressive ERA AND NeW DEAL Years 131-82 (2001) (describing the ascendancy of regulation precluding women's workplace participation). By contrast, the Lochner era Court invalidated some two hundred regulatory measures restricting (men's) ability to freely contract. Strauss, supra note 121, at 373.

${ }^{129}$ Pub. L. No. 88-352, 78 Stat. 241 (codified as amended in scattered sections of 42 U.S.C.); see also Miss. Univ. for Women v. Hogan, 458 U.S. 718, 729 (1982) (observing that sex-based differential treatment was merely a codification of empirically unsubstantiated social conventions); Frontiero v. Richardson, 411 U.S. 677, 686 (1973) (holding as a general, empirically verified proposition that one's sex was frequently unrelated "to ability to perform or contribute to society").

${ }^{130}$ See, e.g., Dothard v. Rawlinson, 433 U.S. 321, 328 (1977) (noting that Title VI "required 'the removal of artificial, arbitrary, and unnecessary barriers" to women's employment) (quoting Griggs v. Duke Power Co., 401 U.S. 424, 431 (1971)). Although Dothard is the only post-Title VII holding by the Court to exclude women from occupational opportunity on safety grounds, what is important here is the methodology utilized rather than the result achieved.

${ }^{131}$ For a theoretical inquiry into the elements that unite disability discrimination law with that of feminist and communitarian philosophies, see Carlos A. Ball, Looking for Theory in all the Right Places: Feminist and Communitarian Elements of Disability Discrimination Law, 66 OHIO ST. L.J. (forthcoming 2005). 


\section{The Fixed Identity of African Americans}

Canonical scholarship also distinguishes the treatment of people with disabilities from that of other protected groups because it conceives of and discusses disability as a biologically compelled reality, rather than as a contingent social construct. In so doing, these scholars make the same error about disability that the law made about race in earlier times: they drape an issue of variable social construction in the guise of fixed scientific veracity. ${ }^{132}$

Historically, race was treated as a biologically absolute reality, one that could be determined scientifically by the percentage of non-white ancestry an individual possessed. ${ }^{133}$ Consequently, states passed statutes designating how much African "blood" was needed to classify a person as black. ${ }^{134}$ This percentage varied from state to state: for example, being one-thirty-second black in Alabama, ${ }^{155}$ as compared with one-fourth black in Virginia, categorized an individual as legally black. ${ }^{136}$ Consequently, historians of race (as well as Critical Race

${ }^{132}$ See, e.g., Peter David Blanck \& Michael Millender, Before Disability Civil Rights: Civil War Pensions and the Politics of Disability in America, 52 ALA. L. REv. 1, 2-3 (2000) (" $[\mathrm{T}]$ he medical model never questioned the physical and social environment in which disabled people were forced to function ....").

${ }^{133}$ See, e.g., IAN F. HANEY LÓPEZ, White by LAW: THE Legal CONSTRUCtion OF RACE 118-19 (1996) (listing the different tests that states employed to determine the amount of African blood needed to make a person "black"). According to the notion of the times, there were five distinct races: Mongolian (yellow), Negro (black), Caucasian (white), Indians of North and South America (red), and Malay (brown). One system, however, identified some twenty-nine races. Gary A. Greenfield \& Don B. Kates, Jr., Mexican Americans, Racial Discrimination, and the Civil Rights Act of 1866, 63 CAL. L. REV. 662, 676-94 (1975); see also Henry P. Lundsgaarde, Racial and Ethnic Classifications: An Appraisal of the Role of Anthropology in the Lawmaking Process, 10 HOUS. L. REV. 641, 648 (1973) (demonstrating that "[a]ny scientific definition of race . . must clearly distinguish between taxonomic criteria within the species, and the scientific purpose served by such a classification").

${ }^{134}$ Some commentators assert that the "one-drop rule," meaning any black ancestry, was sufficient to denote black identity. F. JAMES DAVIS, WHO IS BLACK? ONE NATION'S DEFINITION 5 (1991); see also Trina Jones, Shades of Brown: The Law of Skin Color, 49 DUKE L.J. 1487, 1495 n.25 (2000) ("[F]or much of its history in the United States, the Black race has been defined by the one-drop rule."). Whichever interpretation is ultimately correct, the common theme is that some percentage of black ancestry, however much it might have been, was considered sufficient to "taint" a person's identity. See Neil Gotanda, A Critique of "Our Constitution is Color Blind," 44 STAN. L. REV. 1, 26-27 (1991) (discussing the "one drop of blood" rule).

${ }^{135}$ ALA. CODE $\$ 2$ (1923). For a discussion of the significance of this classification to miscegenation cases in that state due to its large black population and racist tendencies, see Julie Novkov, Racial Constructions: The Legal Regulation of Miscegenation in Alabama, 1890-1934, 20 LAW \& HIST. REV. 225, 236-50 (2002).

${ }_{136}$ See A. Leon Higginbotham, Jr. \&e Barbra K. Koppytoff, Racial Purity and Interra- 
scholars $)^{137}$ have uniformly and correctly argued that race was not, in fact, inherently biological, but was instead a socially constructed and politically contingent category. ${ }^{138}$

Ariela Gross's scholarship on the historical use of law in determining race adds further evidence to the notion of race as a social construct. ${ }^{139}$ Gross wisely demonstrates how, because the fractions of blood were not determinative, trials in nineteenth century southern county courts investigated the "racial 'essence' inhering in one's blood" by asking juries to decide whether particular individuals "performed" white or black roles. ${ }^{140}$ These trials turned on evidence presented by neighbors and other community witnesses about the way a given person acted in the community, their civic acts, associations, and

cial Sex in the Law of Colonial and Antebellum Virginia, 77 GEO. L.J. 1967, 1978 (1989) (citing 12 THE STATUTES AT LARGE, BEING A COLLECTION OF ALl THE LAWS OF VIRGINIA 184 (William Waller Hening ed., 1823) (enacted 1785; effective 1787)).

${ }^{197}$ Thus, according to John Calmore, "Critical Race Theory begins with a recognition that 'race' is not a fixed term. Instead, 'race' is a fluctuating, decentered complex of social meanings that are formed and transformed under the constant pressures of political struggle." John O. Calmore, Critical Race Theory, Archie Shepp, and Fire Music: Securing an Authentic Intellectual Life in a Multicultural World, 65 S. CAL. L. REV. 2129, 2160 (1992); see also HANEY LóPEZ, supra note 133, at 13. Haney López examines four factors that characterize the struggle leading to the formation of race. According to him:

First, humans rather than abstract social forces produce races. Second, as human constructs, races constitute an integral part of a whole social fabric that includes gender and class relations. Third, the meaning-systems surrounding race change quickly rather than slowly. Finally, races are constructed relationally, against one another, rather than in isolation.

Ian F. Haney López, The Social Construction of Race: Some Observations of Illusion, Fabrication, and Choice, 29 HARV. C.R.-C.L. L. REV. 1,28 (1994).

${ }^{138}$ See, e.g., HANEY LóPEZ, supra note 133, at 124 (averring that law served to "legitim [ize] the existence of race" as a category); see also DAVIS, supra note 134, at 1-15 (discussing the social construction of race); SCOTT MALCOMSON, ONE DROP OF BLOOD: THE AMERICAN MISADVENTURE OF RACE 11-122 (2000) (discussing racial identities of Native Americans); EDMUND S. MORGaN, AMERICAN SLAVERY, AMERICAN FreEdOM: THE ORDEAL OF COLONIAL VIRGINIA 328-37 (1975) (describing Virginia's statutory approach to race in the seventeenth and early eighteenth centuries).

${ }^{139}$ See Ariela Gross, Beyond Black and White: Cultural Approaches to Race and Slavery, 101 Colum. L. REV. 640, 688 (2001) ("The legal history of race and slavery may be seen as a case study of the relationship between law and social norms."); Ariela Gross, Pandora's Box: Slave Character on Trial in the Antebellum Deep South, 7 YaLE J.L. \& Human. 267,271 (1995) (analyzing "the legal constructions of black character" during slavery); see also Susan F. Hirsch \& Mindie Lazarus-Black, Introduction to CONTESTED STATES: LAW, HEgEMONY AND RESISTANCE 1, 10 (Mindie Lazarus-Black \& Susan F. Hirsch eds., 1994) (providing trenchant accounts of courts as foras for "performing" racial roles).

${ }_{140}$ What follows owes a deep debt to the superlative Ariela J. Gross, Litigating Whiteness: Trials of Racial Determination in the Nineteenth-Century South, 108 YALE. L.J. 109, 111-12 (1998). 
general demeanor, as the means of determining racial status. ${ }^{141}$ In some cases, judges gave juries guidance on what evidence they could consider; in others, juries were instructed as to the effect their rulings would have, but were otherwise left to their own devices. ${ }^{142}$ Gross concludes from her study of sixty-eight such trials that legal categories did not themselves define a person's race in the antebellum South. According to Gross, the defining law of this period was not limited to "coercive rules handed down from high courts and legislatures." Also contributing to this definition of race were more subtle factors, such as the identity of the litigants (and the arguments they chose), the jurors, and the community members who testified as witnesses. ${ }^{144}$

In contrast to the nineteenth century circumstances described by Gross, race is now acknowledged as a social construct, rather than a biological truism. ${ }^{145}$ A good illustration of this fact is the treatment of race as capable of encompassing more than only one category ("multiracial") in the most recent Census, a significant break with past practice as this is the first time that individuals may claim multiple racial identities. ${ }^{146}$ Moreover, scientific evidence clearly indicates that, from

141 Id. at 112-13.

${ }^{142}$ This approach was explained by Judge Roane in the case of Hudgins $v$. Wright, 11 Va. (1 Hen. \& M.) 134, 141-43 (1806) (Roane, J.). In describing Roane's view, Gross writes, "trials of racial determination required testimony as to ancestry, reputation in the community, other socially and legally defined criteria, as well as physiology and medical science." Gross, supra note 140, at 130. Some judges believed that jurors needed only to look at the litigant to determine his or her race. See, e.g., id. at 129 (noting one particular judge's belief in "the reliability of appearance").

${ }^{143}$ Gross, supra note 140 , at 181.

${ }^{144}$ Id. at 130-32. The Supreme Court has also interpreted racial identity. See, e.g., United States v. Bhagat Singh Thind, 261 U.S. 204, 215 (1923) (holding that an Indian high-caste Hindu was not a white person for purposes of immigration); Yamashita $v$. Hinkle, 260 U.S. 199, 200 (1922) (same for Japanese immigrant); United States v. Wong Kim Ark, 169 U.S. 649, 694 (1897) (same for Chinese immigrant); see generally Joel Perlmann, "RACE OR PEOPLe": Federal RaCE Classifications for EuROPEANS IN AMERICA, 1898-1913, (Jerome Levy Economics Institute Working Paper No. 320, 2001) (surveying legal treatment of European individuals) available at $\mathrm{http}: / /$ www.levy.org/pubs/wp/320.pdf. This is a different inquiry from assessing the constitutionality of statutes that exclude individuals on the basis of race, which the Court has done with mixed results. Compare Brown v. Bd. of Educ., 347 U.S. 483, 495 (1954) (striking down as unconstitutional "separate but equal" status in education), with Plessy v. Ferguson, 163 U.S. 537, 550-51 (1896) (upholding the constitutionality of legal segregation on public railways)

${ }^{145}$ Charles F. Abernathy, Advocacy Scholarship and Affirmative Action, 86 GEO. L.J. 377, 400 (1997) (book review) ("Psychologists, sociologists, and others now widely agree that race is a 'social construct."').

${ }^{146} \mathrm{See}$ U.S. CENSUS BUREAU, RACIAL AND ETHNiC ClaSSIFICATIONS USED IN CENSUS 2000 AND BEYOND, at http://www.census.gov/population/www/socdemo/race/ 
a genetic perspective, race is either a nonexistent or an insignificant factor, at least insofar as one's DNA identity. ${ }^{147}$

Thus, the current treatment of disability mirrors that of the historical treatment of race. In each circumstance, law was the vehicle through which socially contingent definitions were held out as immutable biological reality. In the context of race, the drops-of-blood laws ascertained fixed identity. The identities of both groups of individuals, respectively, were couched in terms of neutral scientific principles that in turn prescribed people's appropriate social roles. ${ }^{148}$

racefactcb.html (Apr. 12, 2000) (explaining that the change in Census practice stems from considering race and ethnic origin as separate concepts); see also Cindy Rodríguez, Census Cites Growing Diversity, BOSTON GLOBE, Mar. 13, 2001, at A2 (reporting that the 2000 Census was the first in which "Americans were able to choose more than one racial group").

${ }^{147}$ Specifically, any two humans are likely to have their DNA sequences differ by only $0.1 \%$. More broadly, some $95 \%$ of all genetic variation exists within a population, whereas variation between different populations only accounts for between $3 \%$ and $5 \%$ of the total. Noah A. Rosenberg et al., Genetic Structure of Human Populations, 298 SCI. 2381,2381 (2002). The variation is generally attributed to differences among five distinct population groups. Mary-Claire King \& Arno G. Motulsky, Mapping Human History, 298 SCI. 2342, 2342-43 (2002). Those scientists who do assert the pertinence of race do so because race correlates to certain anomalies (for example, African Americans are disproportionately susceptible to sickle cell anemia, and Ashkenazi Jews are disproportionately vulnerable to Tay-Sachs disease), and thus race remains a relevant variable for some research purposes. See Morris W. Foster \& Richard R. Sharp, Race, Ethnicity, and Genomics: Social Classifications as Proxies of Biological Heterogeneity, 12 GENOME RES. 844, 849 (2002) (describing the debate and tension over the last decade between those who view racial and ethnic categories as biologically meaningful and those who assert that race and ethnicity are social classifications with little or no biological significance); Nicholas Wade, Race is Seen as Real Guide to Track Roots of Disease, N.Y. TIMES, July 30, 2002, at F1 (“[A] leading population geneticist says that race is helpful for understanding ethnic differences in disease and response to drugs."). At the same time, the correlations are not that clear. See, e.g., Richard S. Cooper et al., Race and Genomics, 348 NEW ENG. J. MED. 1166, 1168 (2003) ("Race . . has not been shown to provide a useful categorization of genetic information about the response to drugs, diagnosis, or causes of disease."). Because the majority of African Americans have European ancestors, and all European Americans (and Europeans) have African ancestors, one commentator advises that racial categories "disguise[] rather than acknowledge[] our multifaceted histories." STEVE OLSON, MAPPING HUMAN HISTORY: Discovering THE PAST THROUGH OUR GENES 69 (2002).

${ }^{148}$ See Janet E. Halley, Sexual Orientation and the Politics of Biology: A Critique of the Argument from Immutability, 46 STAN. L. REV. 503, 546-66 (1994), for the argument that strong parallels also exist between the "constructivism" debates of race and that of sexual orientation. 


\section{Civil Rights Always Engender Cost}

Antidiscrimination theory, as expressed in the canonical principle, seeks to compel employers to treat groups that have historically been excluded from workplace opportunity in the same manner that they treat individuals of equal economic value from the empowered majority. In this scheme, employers who themselves possess biased tastes respond to the prejudicial feelings held by third parties (such as customers or existing employees), or rely on inaccurate proxies of productivity, to justify the illegal and inefficient exclusion of certain groups. Civil rights statutes respond to this situation by coercing the inclusion of protected class members. Consequently, an employer's previously held misperceptions about the "relevant" characteristics of particular groups are corrected. In addition, the workplace is rendered more efficient because now each employee is treated "impersonally" according to her "economic function," meaning her actual net-profit value. ${ }^{149}$

It is important to emphasize that the canonical framework assumes that the economic worth of disabled employees is at issue, not their moral worth, and that the two assessments under this analysis are distinct from one another. Put another way, canonical scholarship posits as a factual matter that rational discrimination distinguishes the exclusion of accommodated disabled workers from that of members of other protected classes. This is because hiring accommodated workers with disabilities engenders cost, whereas hiring nonaccommodated workers does not. These scholars believe that as a byproduct of capitalistic rationality, excluding disabled employees on economic efficiency grounds does not raise the same ethical issues of wrongdoing as does irrational omission of other workers. Thus, although the canonical framework acknowledges the legal obligation of employers to accommodate disabled workers under the ADA-a requirement to which the scholarship does not object as a matter of social policy-it nevertheless views that requirement as one that is different from that of more established antidiscrimination measures. ${ }^{150}$

\footnotetext{
149 See Kelman, Market Discrimination, supra note 24, at 841 ("An employer discriminates insofar as he treats the plaintiff employee or job applicant worse than he treats statistically typical employees or applicants whose marginal product is no higher.").

150 Id. This is a position with which Bagenstos takes issue, arguing that employers are under a moral obligation to remedy historic exclusion of disabled workers. Bagenstos, supra note 16, at 845-66. Owen Fiss and Paul Brest each took similar positions in the context of racial discrimination. See Fiss, supra note 70, at 260 ("[T]o the victim
} 
Contrary to the canonical view of traditional antidiscrimination measures, applying the remedies provided by Title VII and other traditional regulations always engenders cost to employers because civil rights laws challenge, and when necessary amend, discriminatory workplace norms. Moreover, even when providing accommodations is more expensive than not accommodating equivalently nondisabled workers (a circumstance that will certainly occur for some unknown part of that population), accommodation costs are similar to expenses raised in the context of ameliorating sex or race discrimination in that they each remedy historical exclusion.

An initial failing in the canonical conception is the notion that traditional civil rights laws only compel irrational employers to swap employees that are equal in their productivity value. This has a central flaw in assuming that workers of equal profitability are fungible, i.e., that replacing an employee with majority characteristics with an economically identical one who also happens to have certain protected group characteristics is a cost-free endeavor. ${ }^{151}$ Yet, a primary remedy in Title VII cases is reinstatement of the claimant to the position from which she has been wrongfully excluded and another individual put in her place. ${ }^{152}$ As a practical consequence, traditional antidiscrimination measures require employers either to employ a greater number of individuals for the same position (thus incurring redundancy costs) or to dismiss an equivalent number of "wrongfully" employed workers and thereby sustain severance expenses. ${ }^{153}$ A suc-

of the employment decision the appearance of the conduct is identical, whether the use of race is efficiency-related or not."); Paul Brest, Foreword: In Defense of the Antidiscrimination Principle, 90 HARV. L. REV. 1, 7 (1976) (" $[R]$ ace-dependent decisions that are rational and purport to be based solely on legitimate considerations are likely in fact to rest on assumptions of the differential worth of racial groups or on the related phenomenon of racially selective sympathy and indifference."). I agree with these three scholars as to employers' moral obligations, but I do not concede that the costs disabled workers engender are different in kind from those imposed by other groups seeking to eradicate artificial barriers, even if I would acknowledge that due to the greater systemic environmental exclusion, those costs may be greater in degree.

151 See Kelman, Market Discrimination, supra note 24, at 892 (asserting that a plaintiff wishing to "block simple discrimination asks to be treated no worse than others who are equivalent sources of money ... or embodied net marginal product").

${ }^{152}$ See Franks v. Bowman Transp. Co., 424 U.S. 747, 763, 765-66 (1976) (holding that reinstatement and retroactive seniority are remedies available under Title VII).

${ }^{153}$ As a general matter, courts award discrimination victims priority in applying for vacancies, but do not force employers to displace present jobholders. An exceptional displacement case is Walters $v$. City of Atlanta, 803 F.2d 1135 (11th Cir. 1986), wherein the court ordered the city to "bump" the current employee and instate the plaintiff due in part to the "uniqueness of the position" which the plaintiff was denied. Id. at 1148-50. 
cessful Title VII employee will also be entitled to back pay covering the period between her wrongful exclusion and the filing of suit (an expense that yields no profit whatsoever), ${ }^{154}$ as well as any difference in pay during that period (a differential which itself might have motivated the employer) ${ }^{155}$ and during the remainder of her employment. ${ }^{156}$

Furthermore, it is factually incorrect to assume that successful Title VII claimants never engender expenses, for courts can, and frequently do, mandate changes to employers' businesses. Hiring members of previously excluded groups can require the building of new facilities, as in the case of restrooms or locker rooms for women, or the provision of alternatively sized uniforms for protected group members who are sized differently. ${ }^{157}$ Remedying discrimination can also invoke less immediately obvious expenses when altering business practices, including methods of job testing or administration. ${ }^{158}$ These last emendations can be very expensive, as demonstrated by the terms of some recent class action settlements for race- and sex-based employment discrimination. ${ }^{159}$ To cite just two examples, Coca-Cola's $\$ 192.5$ million settlement for racial discrimination included $\$ 43.5$ million for changes in human resource programs so as to prevent future

${ }^{154}$ See Pettway v. Am. Cast Iron Pipe Co., 494 F.2d 211, 251-63 (5th Cir. 1974) (allowing back pay as a remedy in a disparate impact case).

${ }^{155}$ See Franks, 424 U.S. at 764 n.21 (holding that, to achieve the congressionally mandated goal of closing the "earnings gap," the "other consequences" of discriminatory practices on back pay, such as loss of potential seniority, should be considered when determining what pay is owed); Love v. Pullman Co., No. C-899, 13 Fair Empl. Prac. Cas. (BNA) 423, 427 \& n.6 (D. Colo. 1976) (applying Franks in calculating back pay to include wages and seniority lost due to discriminatory practices).

${ }^{156}$ Because of these considerations, Title VII suits require courts to give a lot of thought on how to fashion remedies for wrongfully excluded workers without also penalizing those "innocent" employees who had been hired or promoted in their place.

${ }_{157}$ See, e.g., Lynch v. Freeman, 817 F.2d 380, 388 (6th Cir. 1987) (overturning a district court ruling that the lack of a sanitary toilet did not establish sex discrimination under Title VII); see also EEOC Guidelines on Discrimination on the Basis of Sex, 29 C.F.R. $§ 1604.2$ (b) (5) (2004) ("Some States require that separate restrooms be provided for employees of each sex. An employer will be deemed to have engaged in an unlawful employment practice if it refuses to hire or otherwise adversely affects the employment opportunities of applicants or employees in order to avoid the provision of such restrooms ....")

${ }^{158}$ See United States v. City of San Francisco, 656 F. Supp. 276, 283-85 (N.D. Cal. 1987) (upholding plaintiff's claims that San Francisco's entry-level and promotional firefighter exams violated Title VII).

${ }^{159}$ For a thorough description of three exemplary settlements, including a finding that employment discrimination class action suit settlements do not substantially effect stock prices, see Michael Selmi, The Price of Discrimination: The Nature of Class Action Employment Discrimination Litigation and Its Effects, 81 TEX. L. REV. 1249, 1268-98 (2003). 
discrimination in promotion and pay, ${ }^{160}$ similarly, $\$ 35$ million of the $\$ 172$ million that Texaco agreed to in its racial discrimination settlement went to pay for a five-year task force to revise its personnel programs. ${ }^{161}$

Additionally, economist Kenneth Arrow noted over three decades ago that intentional (and therefore, more morally reprehensible) discrimination can be both economically rational and profitmaximizing. ${ }^{162}$ Forcing an employer's choice of an employee will cost that employer both in terms of autonomy (due to coercion) and in terms of third-party preferences (such as clients or coworkers who are disinclined towards members of the protected class). ${ }^{163}$ This is true whether those third-party preferences were legitimate (as in customers who desire clean-shaven pizza deliverers because they are averse to unshaven men coming to their doors at night) ${ }^{164}$ or illicit (for example, lascivious businessmen who will fly only on airlines with attractive female flight attendants). ${ }^{165}$ The same is true when an employer util-

160 Abdallah v. Coca-Cola Co., 133 F. Supp. 2d 1364, 1371 (N.D. Ga. 2001).

161 Roberts v. Texaco, Inc., 979 F. Supp. 185, 191-92 \& n.6 (S.D.N.Y. 1997); cf. Settlement Agreement, Burton v. Toshiba Am. Consumer Prod., Inc., No. 3:01CV21 (M.D. Tenn. 2002) (agreeing, as part of a \$1.4 million settlement, to implement specific antidiscrimination measures, including management training programs) (on file with author); Butler v. Home Depot, Inc., No. 94-4335 SI (N.D. Cal. Jan 14, 1998) (providing, as part of a $\$ 65$ million sex discrimination settlement, for $\$ 17$ million to be spent on upgrading the company's human resource programs) (consent decree, on file with author); Haynes v. Shoney's, Inc., No. 89-30093-RV, 1993 U.S. Dist. LEXIS 749, at *1720, *86-92 (N.D. Fla. Jan. 25, 1993) (providing, as part of a $\$ 105$ million race discrimination settlement, for the creation of training and education programs and the expansion of a tuition reimbursement program to reimburse black employees for continuing education).

${ }^{162}$ Kenneth J. Arrow, Models of Job Discrimination, in RACIAL DISCRIMINATION IN ECONOMIC LIFE 83, 83-87 (Anthony H. Pascal ed., 1972) (showing that lack of available workers and inequalities in education level cannot account by themselves for wage disparities between blacks and whites).

${ }^{163}$ Elizabeth F. Emens, The Sympathetic Discriminator: Mental Illness and the ADA, 93 GEO. L.J. (forthcoming 2005), argues that in the context of people with mental disabilities, employers are required to bear the "hedonic costs"-i.e., emotional and psychic discomfort-that those individuals inevitably and irremediably inflict upon third party coworkers and clients. I am not convinced that whatever discomfort is caused by the presence of a person with a mental (as opposed to physical) disability is either inexorable or insurmountable.

${ }^{164}$ See Bradley v. Pizzaco of Neb., Inc., 7 F.3d 795, 797-99 (8th Cir. 1993) (striking down a no-beard policy despite testimony and evidence on the effect it would have upon future sales).

${ }^{165}$ See Wilson v. Southwest Airlines Co., 517 F. Supp. 292, 298-99 (N.D. Tex. 1981) (disallowing an employer's policy of catering to male business travelers by hiring only female flight attendants). 
izes rational statistical discrimination, meaning that the proxies used for measuring the relative average productivity of members of a given group turn out in the end to be accurate (i.e., that clean-shaven pizza deliverymen or comely female-staffed airlines offer greater appeal to their clients) and therefore yield greater profit. ${ }^{166}$ Each circumstance leads courts to set aside preferences, and in doing so imposes a cost on employers. ${ }^{16}$

Moreover, other examples of how discrimination can be rational in excluding members of a protected group abound, even when viewed in a nondiscriminatory light. Consider, for instance, that hiring a woman rather than a man may be, on average, more expensive because women live longer and therefore engender greater pension costs, ${ }^{168}$ and that women alone are functionally capable of childbirth. ${ }^{169}$ Thus, the premise that race or sex-based discrimination on the basis of those group characteristics is economically irrational is erroneous. ${ }^{170}$ Not only does rational discrimination exist in the sex and race arenas, but the Supreme Court has gone to lengths to prohibit it un-

${ }^{166}$ For an overview of rational discrimination, see Kenneth J. Arrow, The Theory of Discrimination, in DISCRIMINATION IN LABOR MARKETS 3 (Orley Ashenfelter \& Albert Rees eds., 1973); Edmund S. Phelps, The Statistical Theory of Racism and Sexism, 62 AM. ECON. REV. 659 (1972). For an argument that rational statistical discrimination is the most significant current race discrimination problem, see GLENN C. LOURY, THE ANATOMY OF RACIAL INEQUALITY (2002).

${ }^{167}$ This point has been made before by Jolls, supra note 10, at 651-52 ("Employers are often required by disparate impact law to incur special costs ... [even when] the employer had no intention of treating the group differently on the basis of group membership."); see also Bagenstos, supra note 21, at 464 (emphasizing the necessity of antidiscrimination statutes where discrimination against people with disabilities is statistically rational). In passing, empirical studies also note that attractive workers are likely to be better paid (and presumably more profitable) than less attractive ones. See Daniel S. Hamermesh \& Jeff E. Biddle, Beauty and the Labor Market, 84 AM. ECON. REv. 1174,1192 (1994) ("[W] e find some evidence of a positive impact of workers' looks on their earnings.").

${ }^{168}$ For a practical application of this concept, see City of L.A. Dep't of Water E Power v. Manhart, 435 U.S. 702, 704 (1978) (rejecting a discriminatory pension funding policy despite noting that "[a]s a class women live longer than men"); id. at 705 (reporting that, "[b]ased on a study of mortality tables and its own experience" the employer found " $[t]$ he cost of a pension for the average retired female is greater than for the average male retiree").

${ }^{169}$ Accordingly, antidiscrimination protection for child bearing under Title VII or the Pregnancy Discrimination Act only extends to women. By contrast, childcare (and other family caring situations) under the FMLA extends to all individuals regardless of sex. See Rabin-Margalioth, supra note 40, at 113-18 (discussing the reach of, and confluence between, various employment mandates).

${ }^{170}$ Underlying part of that rationality, and uniting it with disability exclusion, is the fact that each of the baselines way designed by the mainstream with only itself in mind. 
der traditional antidiscrimination regulations. For example, the Court held in $U A W v$. Johnson Controls that " $[\mathrm{t}]$ he extra cost of employing members of one sex ... does not provide an affirmative Title VII defense for a discriminatory refusal to hire members of that gender." ${ }^{171}$ Even in circumstances where employers can show that a statistical proxy demonstrating median productivity is an overall correct assessment of the entire group, ${ }^{172}$ or less costly than making individual inquiries, ${ }^{173}$ courts still require an individualized assessment of a specific employee's abilities. ${ }^{174}$ Only when those employers can also demonstrate that "all or substantially all" members of the class are unable to perform the job in question may an employer exclude all members of a given class, ${ }^{175}$ and then only after a costly inquiry into individual ability. ${ }^{176}$

Even if, however, all the arguments put forward in the canonical framework were true-namely, that accommodation is more expensive than nonaccommodation, and accommodating any disabled worker is more expensive than not accommodating any other worker-they still cannot distinguish the ADA in kind from Title VII and other traditional antidiscrimination norms. The expenses engendered by those plaintiffs may vary in degree for a number of reasons, including Title VII's twenty-six-year head start on the ADA, the heterogeneity of disabled people, and the efficacy of enforcement, but these do not distinguish the statutes in kind. This is because part and

171499 U.S. 187, 210 (1991); see also Griggs v. Duke Power Co., 401 U.S. 424, 433 (1971) ("The facts of this case demonstrate the inadequacy of broad and general testing devices as well as the infirmity of using diplomas or degrees as fixed measures of capability.").

${ }^{172}$ Cf. Christine Jolls, Hands-Tying and the Age Discrimination in Employment Act, 74 TEX. L. REV. 1813, 1814 (1996) (noting astutely that retaining less productive older workers might be more economically efficient in the long run).

${ }^{173}$ As such, statistical discrimination is rational from a second perspective. CASS R. Sunstein, Why Markets Don't Stop Discrimination, in FREE MARKETS ANd SOCIAL JUSTICE 151,156 (1997)

174 "Employers ... are still required to base their hiring decisions ... upon an assessment of the relevant qualities of each individual applicant." Rubin, supra note 102, at 572 .

${ }^{175}$ See W. Air Lines, Inc. v. Criswell, 472 U.S. 400 (1985) (overturning forced retirement policy for all flight engineers over sixty years of age); Weeks v. S. Bell, 408 F.2d 228 (5th Cir. 1969) (overturning gender-discriminatory hiring policy where the employer failed to show that all or substantially all women could not perform the duties involved).

${ }^{176}$ See, e.g., City of L.A. Dep't of Power \& Water v. Manhart, 435 U.S. 702, 708 (1978) ("Even a true generalization about the class is an insufficient reason for disqualifying an individual to whom the generalization does not apply."). 
parcel of antidiscrimination jurisprudence is the requirement that employers bear costs to remedy the artificial exclusion of protected groups from the workplace. And, as is shown below, ADA accommodations do just that. ${ }^{17}$

Thus, the canonical premise that traditional civil rights remedies do not engender costs, but disability accommodations do, is factually erroneous. All civil rights actions engender cost in that they change an instantiated and prejudicial status quo.

\section{The Continuum of Perceived Biological Difference}

Disability-related civil rights are the most recent empowerment of a group that society perceives as biologically atypical. Nonetheless, at least in part due to the unique civil rights chronology of people with disabilities, notions and perspectives that would be considered retrograde when applied to women or African Americans continue to influence assessments of the disabled. This is especially apparent when reviewing the Supreme Court's disability-related jurisprudence.

\section{Links in the Civil Rights Chain}

The ADA is the newest law empowering a perceived biologically atypical group with civil rights. Prior to granting disabled persons rights through the $\mathrm{ADA}$, society recognized the legal rights of women and African Americans. ${ }^{178}$ Thus, although canonical scholars view those individuals as equal to, respectively, men and white Americansand would probably be taken aback by anyone who did not-those selfsame scholars uniformly (and ironically) adhere rigorously to the analogous position that people with disabilities are, both as a logical and an empirical matter, inherently less capable than nondisabled persons. ${ }^{179}$

${ }^{177}$ Infra Part III.A.

${ }^{178}$ See supra Part II.B (discussing historical lessons from the struggle for civil rights); see also, e.g., Angela P. Harris, Equality Trouble: Sameness and Difference in Twentieth-Century Race Law, 88 CAL. L. REV. 1923, 1989-96 (2000) (discussing the civil rights movement for African Americans); Michael Straubel, Gender Equity, College Sports, Title IX and Group Rights: A Coach's View, 62 BROOK. L. REV. 1039, 1041 (1996) (describing Title IX as "the legal force behind the push for gender equity").

${ }^{179}$ See supra Part II.A.l (rebutting the canonical assumptions about accommodation costs); Hahn, supra note 72, at 103 ("Disabled persons probably comprise the only group that has not yet been successful in refuting accusations of biological inferiority."). 
Further along the continuum, and therefore still fighting for legal recognition, are individuals with nonmajority sexual orientations, most notably gays and lesbians. ${ }^{180}$ On the federal level, ${ }^{181}$ those individuals have been left without specific protection, ${ }^{182}$ are prohibited from expressing their identities in the military ${ }^{189}$ or through marriage or marriage-like arrangements, ${ }^{184}$ are excluded from certain securitylevel positions, ${ }^{185}$ and are denied full immigration rights. ${ }^{186}$

${ }^{180}$ See, e.g., Chai R. Feldblum, The Federal Gay Rights Bill: From Bella to ENDA, in Creating Change: PUblic Policy, Civil Rights, ANd Sexuality 149, 185 (John D'Emilio et al. eds., 2000) (describing the failure to pass the proposed federal Employment Non-Discrimination Act); Laura Grenfell, Embracing Law's Categories: AntiDiscrimination Laws and Transgenderism, 15 YALE J.L. \& FEMINISM 51, 53 (2003) (observing that "traditional Title VII jurisprudence refuses to protect transgender persons from discrimination in the workplace"). Despite the bleak picture painted by these commentators, the present state of lesbian, gay, bisexual, and transgendered rights marks an improvement over the situation in 1966, when Time magazine published an essay describing homosexuality as "a pathetic little second-rate substitute for reality." The Homosexual in America, Time, Jan. 21, 1966, at 41. Today, some large corporations provide benefits to same-sex partners. See D'EMILIO, Introduction to CREATING CHANGE: PUblic POLICY, CIVIL RIGHTS, AND SEXUALITY, supra at vii (detailing advances in civil rights for same-sex couples over the past thirty years).

${ }^{181}$ Some states, however, have passed antidiscrimination protections. See William Rubenstein, Do Gay Rights Laws Matter?: An Empinical Assessment, 75 S. CAL. L. REV. 65, 69 (2001) (debunking the myth that state antidiscrimination laws that include sexual orientation as a protected category rarely see litigation action). Rubenstein uses data from the states that have passed laws prohibiting discrimination based on sexual orientation to combat the argument that gay workers do not exercise their rights as regularly as other protected groups. Id. at 67 . He concludes that those workers use the laws that are designed to protect them and that, when protected, gay workers may even exercise their rights at a "slightly higher" rate than female workers. Id. at 68 . For examples of the variety of states' gay rights laws, see CAL. GOV'T CODE $\$ 12940$ (West Supp. 2003); CONN. GEN. STAT. ANN. \$ 46a-81c (West 1995); WIS. STAT. ANN. \$ 111.321 (West 2001).

${ }^{182}$ On occasion, rights are inferential, as in the case of a male suing for Title VII sexual harassment on the basis of having had certain gender stereotypes ascribed to him. See, e.g., Jones v. Pac. Rail Servs., No. 00C5776, 2001 WL 127645, at *1 (N.D. Ill. Feb. 14, 2001) (upholding male plaintiff's ability to maintain a Title VII claim for sexual harassment under circumstances where fellow employees made remarks in the men's locker room that included "your hands are so soft-what are you doing after work?" and "why don't you come strip for me?"). This theme is explored in Mary Anne C. Case, Disaggregating Gender from Sex and Sexual Orientation: The Effeminate Man in the Law and Feminist Jurisprudence, 105 YALE L.J. 1 (1995).

${ }^{183}$ HALLEY, supra note 96, at 1 (challenging the 1993 revisions to the military's policies regarding homosexual service members).

${ }^{184}$ Some courts have recognized a right to same-sex marriage at the state level. See, e.g., Goodridge v. Dep't of Pub. Health, 798 N.E.2d 941, 948 (Mass. 2003) (holding that under the Massachusetts Constitution the state offered no "constitutionally adequate reason for denying civil marriage to same-sex couples"). A question exists, however, as to whether most homosexuals want access to the institution of marriage. See generally Frank Browning, Why Marry?, in SAME-SEX MARRIAGE: PRO AND CON 132 (An- 
Similarly, people with genetic anomalies are generally unprotected at the federal level from employment discrimination. ${ }^{187} \mathrm{Al}-$ though the Constitution and the Privacy Act of 1974 provide some protection against the collection, use, and dissemination of genetic information on privacy grounds, ${ }^{188}$ effective federal regulation specifically protecting individuals from genetic discrimination in employment is almost nonexistent. ${ }^{189}$ As well, the Equal Employment Oppor-

drew Sullivan ed., 1997) (arguing for legal support for nontraditional families as a superior option to same-sex marriage).

${ }^{185}$ See, e.g., James M. Donovan, Baby Steps or One Fell Swoop?: The Incremental Extension of Rights Is Not a Defensible Strategy, 38 CAL. W. L. REV. 1, 10 (2001) ("Senate Republicans blocked James Hormel's confirmation as the U.S. Ambassador to Luxembourg because he was an openly gay man.").

${ }^{186}$ See Desiree Alonso, Note, Immigration Sponsorship Rights for Gay and Lesbian Couples, 8 CARDOZO WOMEN's L.J. 207, 212 (2002) (arguing that the "family-based immigration sponsorship program discriminates against U.S. citizens who are in bi-national relationships with same-sex partners").

${ }^{187}$ See Anita Silvers \& Michael Ashley Stein, An Equality Paradigm for Preventing Genetic Discrimination, 55 VAND. L. REV. 1341, 1343-45 (2002) (noting that the ADA applies only to severely symptomatic individuals, while genetic discrimination law covers those who are nonsymptomatic or asymptomatic, leaving presymptomatic individuals exposed). By contrast, the scope of state statutes varies by jurisdiction. About half of the jurisdictions prohibit workplace discrimination on the grounds of genetic information, and a handful of jurisdictions have established individuals' property rights to their personal DNA information. Id. at 1346-48.

${ }^{188}$ See U.S. CONST. amend. IV (unreasonable searches and seizures); id. amend. V (due process); $i d$. amend. XIV (due process and equal protection); 5 U.S.C. $\$ 552$ (a) (1996 \& Supp. 1999) (describing what records must be made available to the public under the Freedom of Information Act). The qualification reflects both theoretical and practical encumbrances to privacy-based protection. First, it may not be feasible for employers to maintain a firewall between health care records that may reveal employees' genetic conditions and information used in personnel decisions. Second, when a proprietor waives a privacy right for one purpose, the information may no longer be protected from use for other purposes. Third, where more than one person has a property right in certain information, it is unclear how their interests are prioritized with respect to maintaining control. Last, it is not known if circumstances where lack of access to the information threatens public safety, places commercial interests at considerable disadvantage, or deprives the subject of significant benefits override privacy protections. Additionally, genetic information about an individual can be discovered in several different ways, including: a chance remark about family history, a formal requirement to relate family history, dissemination of data accumulated in a medical setting where patients consent to contributing a specimen for certain panels of tests without specifying what is to be learned from the tests, and situations where a physician orders a panel for one reason but the entire set of test results becomes part of the patient's record. Moreover, a genetic anomaly that is at present correlated with one condition may, in the future, be correlated with another, or anomalies may cluster, so that the presence of one suggests the presence of another. Silvers \& Stein, supra note 187 , at $1348-54$.

${ }^{189}$ Specifically, a single executive order bars federal agencies from discriminating in employment on the basis of "genetic information." See Exec. Order No. 13,145, 65 
tunity Commission (EEOC) has had mixed initial success in applying the antidiscrimination provisions of the ADA to the realm of genetic discrimination. ${ }^{190}$

And because people with disabilities are the most recent group to win formal legal recognition, recognizing them as equal requires a general transformation in social attitudes, most especially acknowledgement of disability rights as rights ${ }^{191}$ rather than as a product of

Fed. Reg. 6877 (Feb. 8, 2000) (barring federal employment discrimination on the basis of genetic information). And, despite repeatedly voiced intentions, Congress has yet to pass legislation specifically prohibiting misuse of genetic information in the areas of employment, although a five-year-old bill is (once more) pending. See Genetic Nondiscrimination in Health Insurance and Employment Act, H.R. 602, 107th Cong. (2001) (prohibiting discrimination on the basis of genetic information with respect to health insurance); see also Jeremy A. Colby, Note, An Analysis of Genetic Discrimination Legislation Proposed by the 105th Congress, 24 AM. J.L. \& MED. 443, 443-44 (1998) (discussing legislative responses to advances in genetic research).

Only a handful of cases clearly charging genetic discrimination have been filed by the EEOC, the most prominent (and the only successful) one of which was a settlement in EEOC v. Burlington N. Santa Fe R.R. Co., Civil Action No. C01-4013 (N.D. Iowa) (filed Feb. 9, 2001) (on file with author). Claimants in Burlington Northern, through their EEOC attorneys, alleged genetic discrimination as the result of the railroad's national policy of requiring union members claiming to suffer from carpal tunnel syndrome to submit to DNA tests to determine whether those workers were predisposed to carpal tunnel injuries. Id. By contrast, a second suit alleging genetic discrimination on the basis of adverse employment decisions grounded in predisposition to carpal tunnel injury was dismissed at the summary judgment stage. EEOC v. Woodbridge Corp., 124 F. Supp. 2d 1132, 1139 (W.D. Mo. 2000). Statements, Congressional testimony, and scholarship by EEOC Commissioner Paul Steven Miller indicate that the agency will continue to pursue this line of legal argument. See Paul Steven Miller, Genetic Discrimination in the Workplace, 26 J.L. MED. \& ETHICS 189, 191 (1998) (discussing the application of federal statutes to genetic discrimination); Paul Steven Miller, Is There a Pink Slip in My Genes?: Genetic Discrimination in the Workplace, $3 \mathrm{~J}$. HEALTH CARE L. \& POL'Y 225, 237-47 (2000) (outlining concerns about genetic discrimination and suggesting methods for addressing such discrimination). Although the articles were written in his personal capacity, his view of the agency's position has also been reiterated in statements made in his authorized capacity. For example, Miller has stated that the EEOC "will continue to respond aggressively to any evidence that employers" misuse genetic information. See EEOC Settles First ADA Genetic Discrimination Suit, EEOC Compliance MANUAL REP. No. 157, at 1, 2 (EEOC, Milwaukee, Wisc., Apr. 27, 2001); see also Prepared Statement of Paul Steven Miller, Commissioner of U.S. Equal Employment Opportunity Commission, Before the Senate Committee on Health, Education, Labor and Pensions (July 20, 2000) (Federal News Service).

${ }^{191}$ The way that discriminatory action against people with disabilities is not even viewed as discrimination raises a parallel circumstance to those Deborah Rhode describes in the context of sex-based prejudice. DEBORAH L. RHODE, SPEAKING OF SEX: The DeNIAL OF GeNDER INEQUALITY (1997). According to Rhode, sex-based discrimination suffers at the hands of the "no problem problem" wherein the "dynamics of denial" fall into three patterns: (1) "denial of gender inequality" or not recognizing challenges that women face; (2) "denial of injustice" in which women's relative lesser socioeconomic position is attributed to an inherent shortcoming; and (3) "denial of 
goodwill. ${ }^{192}$ Ironically, some of the challenges embedded in bringing about a change in the general social attitude towards people with disabilities are exasperated by their unique civil rights chronology, which is set forth in the next section. ${ }^{193}$

\section{A Unique Civil Rights Chronology}

Unlike other marginalized minority groups, disabled Americans were empowered by civil rights legislation prior to a general elevation of social consciousness about their circumstances and capabilities. ${ }^{194}$ Prior to mobilizing in support of the passage of the ADA, the disability rights movement encompassed many individual groups representing distinct disabilities, each advocating on behalf of its own constituency and agenda. ${ }^{195}$ For example, the massive protest by deaf and hearingimpaired students for appointment of a deaf president at Gallaudet University, a higher learning institution for the deaf and hearing impaired, ${ }^{196}$ was unrelated to the advocacy that People First proffered on behalf of developmentally disabled individuals seeking both integration into mainstream society and greater control over the structure of their own lives. ${ }^{197}$ Moreover, these individual disability rights groups

responsibility," which removes personal ability and responsibility to effect change. Id. at $1-3$.

192 Hence, the title of sociologist Richard Scotch's classic story of the disability rights movement needs to be reversed. RICHARD K. SCOTCH, FROM GOOD WILL TO CIVIL RIGHTS (2d ed. 2001).

${ }^{193}$ Additional, extralegal factors that could precipitate change are discussed in the Conclusion, infra.

${ }^{194}$ What follows owes a large debt to SHAPIRO, supra note 4, at 183-210. See generally Thomas F. Burke, On the Rights Track: The Americans with Disabilities Act, in Comparative Disadvantages? Social Regulations and the Global Economy 242 (Pietro S. Nivola ed., 1997) (detailing the failure of the ADA to achieve its stated goals); David Pfeiffer, Overview of the Disability Movement: History, Legislative Record, and Political Implications, 21 POL'Y STUD. J. 724, 726 (1993) (outlining the history of the disability rights movement).

${ }^{195}$ SHAPIRO, supra note 4, at 62.

196 See generally JACK R. GANNON, THE WEEK THE WORLD HEARD GALLAUdET (1989) (relating the story of the week-long student protest that led to the appointment of the first deaf president of Gallaudet University); Mary Elena Fernandez, Gallaudet Recaptures Spirit of Historic '88 March: On Anniversary, Protesters Use Same Route to Press New Concerns for the Deaf, WASH. POST, Mar. 12, 1998, at B3 (same).

${ }^{197}$ See generally Charles Curtis, The Changing Role of the People First Advisor, J. AM. Rehabilitation (Apr. 1984) (detailing the desired qualities for People First mentors), available at http://www.independentliving.org/toolsforpower/tools29.html; People First, at http://www.people1.org/index.htm (describing the organization and posting upcoming events); see also NANCY M. CREWE \& IRVING K. ZOLA, INDEPENDENT LIVING fOR Disabled PeOPle: Developing, Implementing, and Evaluating Self-HelP 
frequently clashed with each other: curb cuts fought for by wheelchair users were opposed by visually-impaired people who needed those same curbs intact to derive a sense of location from their canes. ${ }^{198}$ Nevertheless, the campaign for the ADA's passage unified this previously splintered population. As noted at the time by ADA lobbyist Liz Savage, "People with epilepsy now will be advocates for the same piece of legislation as people who are deaf. That has never happened before. And that's really historic., ${ }^{199}$

Nevertheless, much of the strength of the disability rights movement's success in gaining the ADA's passage came from what Representative Tony Coelho referred to as a "hidden army" of legislators who had instinctive and personal understanding of the stigma attached to disability. ${ }^{200}$ For instance, both Coelho, who sponsored the original ADA bill in the House, and Maryland Representative Steny Hoyer's wife were epileptic. Senator Lowell Weicker of Connecticut, the original sponsor of the ADA bill in the Senate, had a son with Down Syndrome. Senator Bob Dole of Kansas and Senator Bob Kerrey of Nebraska were disabled war veterans. Senator Tom Harkin of Iowa had a deaf brother, Senator Edward Kennedy an amputee son and a developmentally disabled sister, and Senator Orrin Hatch of Utah a post-polio brother-in-law. ${ }^{201}$ Hence, the impetus for changing the legal (and social) regime towards Americans with disabilities was in large measure a personally-driven legislative initiative, rather than a response to a recognized social movement.

Moreover, although efforts to pass the ADA transformed parallel but uncoordinated efforts of disability-specific advocacy groups and

ReHABILITATION PROGRAMS (1983) (discussing the Independent Living movement, which advocates allowing people with disabilities to live in their communities rather than institutions); Dirk Johnson, Tight Labor Supply Creates Jobs for the Mentally Disabled, N.Y. TIMEs, Nov. 15, 1999, at Al (recounting a People First protest of an employer's hiring practices)

${ }^{198}$ See SHAPIRO, supra note 4, at 126 (illustrating how groups view issues in relation to their disability).

${ }^{199}$ Id.; see also Richard K. Scotch, Politics and Policy in the History of the Disability Rights Movement, 67 MILBANK Q. 380, 382-84 (1989) (describing the then-emerging pan-disability rights movement).

${ }^{200}$ See SHAPIRO, supra note 4, at 117-41 (describing how bipartisan will from a broad coalition of legislators and executives, including President Bush himself, enabled the ADA's passage despite little attention to the issue from the public and press). But see Bagenstos, supra note 5, at 927, 954 (arguing that dependency-avoidance was one of the prime considerations impelling the statute's passage, which was "sold to a significant extent as a means of welfare reform").

${ }^{201}$ See SHAPIRO, supra note 4, at 118 (listing personal experience major political figures had with disabilities or with disabled friends and relatives). 
individuals into a unified disability rights movement, this union was short-lived. ${ }^{202}$ People with disabilities remain largely uncoordinated (and sometimes conflicted) ${ }^{203}$ in their activities, without either an acknowledged figurehead (paralleling, for example, Jesse Jackson) or a central political vision (such as that expressed by NOW or NAACP) through which to voice their concerns and desires. ${ }^{204}$ This lack of adhesion has also precluded a univocal litigation strategy, with some deleterious results. ${ }^{205}$

${ }^{202}$ See Michael Ashley Stein, Employing People with Disabilities: Some Cautionary Thoughts for a Second-Generation Civil Rights Statute, in EMPLOYMENT, DISABILITY, AND The Americans wTth Disabilities ACT: Issues in LaW, Public POlicy, and Research 51, 54-56 (Peter David Blanck ed., 2000) (" $[T]$ he history of disability rights advocacy has been one of uncoordinated activity among disparate disability-specific groups. Thus, the disabled have neither a nationally recognized figure ... nor an established central political congress ... through which to voice their concerns and desires.").

${ }^{203}$ Compare, for example, the opposite positions in the right to die debate held by the groups Not Dead Yet, at http://www.notdeadyet.org, opposing physician-assisted suicide, and Compassion in Dying, at http://www.compassionindying.org/info.php, advocating for the right of the terminally ill to die in comfort and dignity by means of physician-assisted suicide. This intradisability conflict is somewhat analogous to the one described within the gay and lesbian community. See Janet E. Halley, The Politics of the Closet: Towards Equal Protection for Gay, Lesbian, and Bisexual Identity, 36 UCLA L. REV. 915, 932-63 (1989) (discussing academic and legal disagreement, both within and outside the gay and lesbian community, about the immutability of homosexual identity); William B. Rubenstein, Divided We Litigate: Addressing Disputes Among Group Members and Lauyers in Civil Rights Campaigns, 106 YALE L.J. 1623, 1639-44 (1997) (highlighting disputes over legal goals and strategies among lawyers pursuing broader gay and lesbian civil rights). For a treatment of broader intergroup conflict arising from conflicting civil rights agendas, see Linda Hamilton Krieger, Civil Rights Perestroika: Intergroup Relations After Affirmative Action, 86 CAL. L. REV. 1251 (1998).

${ }_{204}$ Yet, the formation and continuing development of the American Association of People with Disabilities, with its focus on securing accessible voting and political participation, is a welcome and promising change. Their website is http:// www.aapd.com/.

${ }_{205}$ This is especially true in the context of the idiosyncratic choices made regarding how to litigate ADA cases and then whether to petition the Supreme Court to review those claims. Two examples illustrate this point. In Bragdon v. Abbott, 524 U.S. 624 (1998), the Court held that Abbott, an asymptomatic HrV-positive dental patient, was disabled within the terms of the statute on the narrow ground that fear of transmitting her infection to either a male partner or to their offspring functionally impaired her ability to reproduce. Id. at 641-43. Although Abbott was ultimately victorious, her attorneys could also have litigated the case under the ADA's "regarded as" prong. See 42 U.S.C. $\$ 12,102$ (2) (c) (2000). Framing an argument in that fashion would have raised several issues capable of broader subsequent application, including whether certain conditions are entitled to disability status per se and the extent to which stigma extends the reach of the regarded as prong. For the contrary perspective of one of the architects of that litigation, see Wendy E. Parmet, The Supreme Court Confronts HIV: Reflections on Bragdon v. Abbott, 26 J.L. MED. \& ETHICS 225, 236-37 (1998) (examining the relationship between public health and legal perspectives). Sutton $v$. 
Since people with disabilities were empowered with civil rights absent the necessary political tools and organization for inducing a general elevation in social consciousness, it is not entirely surprising that popular opinion about people with disabilities (which the canonical treatment reflects) has yet to conform to the goals underlying passage of the ADA.

\section{Old Stereotypes Die Hard: The Supreme Court}

As demonstrated above in the context of women's employment participation rights and scientifically "neutral" classifications that defined race, unfounded assertions that were once regularly made about the members of those groups are now considered outmoded and unacceptable. ${ }^{206}$ Nonetheless, analogous assumptions persist in holding that people with disabilities require accommodations due to their atypical biology and that those differences (which render them less capable) are immutable, rather than socially contingent. ${ }^{207}$ The theo-

United Air Lines, 527 U.S. 471 (1999), arose from the certiorari petition of severely myopic twins who were denied positions as global airline pilots for failing to meet the airline's minimum vision requirement, although their vision was correctable with glasses. In affirming this outcome, the Court held that the ADA status of potential claimants was limited to the extent that mitigating measures corrected their disabilities. Thus, the petitioners did not fall under the disability definition because they could correct their impairments. Although the decision can be construed as holding no more than that people who need to wear eyeglasses are not ordinarily considered disabled, see Bagenstos, supra note 21 at $484-85$, it can also be understood as raising a duty to mitigate one's disability. See Hasday, supra note 58, at 13-21. In any event, the Sutton twins raised an extremely unsympathetic claim, which may have contributed to the general backlash against ADA claims. See Krieger, supra note 41, at 10-11 (describing the backlash against ADA claims, asserted by contributors to the symposium).

${ }^{206}$ See supra Parts II.B.1-2 (documenting how widely assumed notions of the frailness of women and the genetic inferiority of African Americans gradually began to dissipate). Consider, as a further example, the memorandum written by Chief Justice Rehnquist as a law clerk to Justice Jackson in preparation for Brown $v$. Board of Education that read: "I think Plessy $v$. Ferguson was right and should be re-affirmed ... the Fourteenth Amendment did not enact ... Myrdahl's [sic] American Dilemma." William H. Rehnquist, A Random Thought on the Segregation Cases (1952), 117 CONG. REC. 45, 440-41 (1971), quoted in Mark V. Tushnet, Making Civil Rights Law: THurgood MARSHALl AND THE SUPREME COURT, 1936-1961, at 190 (1994).

${ }^{207}$ This is not to say that misperceptions about other groups have disappeared, even from the legal academy. See, e.g., Kingsley R. Browne, Sex and Temperament in Modern Society: A Darwinian View of the Glass Ceiling and the Gender Gap, 37 ARIZ. L. REV. 971, 984 (1995) (proclaiming that a good deal of the glass ceiling effect is "the product of basic biological sex differences in personality and temperament"); A. Dean Byrd \& Stony Olsen, Homosexuality: Innate and Immutable?, 14 REGENT U. L. REV. 383, 384-99, 422 (2001) (arguing that, in spite of biological origin, those homosexuals who want to change and become heterosexual can do so through therapy). 
retical consequence of this social convention is the canonical view that treating disabled workers as if they were of a level with nondisabled ones results in those individuals being provided with more-than-equal treatment. Accordingly, disabled participation in society is not a matter of right but is instead contingent on humanitarian considerations and must therefore be measured against competing (and sometimes greater) social need. ${ }^{208}$

Practical application of this misconception is aptly demonstrated in both pre-and post-ADA Supreme Court cases involving people with disabilities. Among the more noteworthy cases that preceded the ADA, Alexander $v$. Choate ${ }^{209}$ recognized the fact of disability discrimination but refused to strike down cost-effective administrative Medicaid regulations that adversely affected the group. ${ }^{210}$ Youngberg $v$. Romeo ${ }^{211}$ held that the constitutional interest in freedom from involuntary confinement of mentally disabled people had to be balanced against "the demands of an organized society,"12 and the Court in Hendrick Hudson Central District Board of Education v. Rowley ${ }^{213}$ ruled that the requirement of a "free appropriate public education" contained in the Education of All Handicapped Children Act of 1975 was "significantly different from any notion of absolute equality," even for those with equal capasbility, and so mandated only the provision of "some educational benefit upon the handicapped child." ${ }^{214}$ Significantly, in City of Cleburne v. Cleburne Living Center, ${ }^{215}$ the Court struck down a zoning ordinance that discriminated against the establishment of group homes for people with mental retardation but proposed that, in contrast to race- or sex-based classifications, disability was not entitled to heightened scrutiny as a quasi-suspect classification. ${ }^{216}$ Although Jus-

208 "Accommodation claims are best conceived of as zero-sum, distributive claims to a finite pot of redistributed social resources, competing not only with the demands of others who seek accommodation ... but with all claimants on state resources." Kelman, Market Discrimination, supra note 24, at 852.

209469 U.S. 287 (1985).

${ }^{210} I d$. at 296, 299.

$211 \quad 457$ U.S. 307 (1982).

${ }^{212}$ Id. at 319-20. According to Chief Justice Burger's separate concurring opinion, he "would hold flatly that respondent ha[d] no constitutional right" at all. Id. at 329.

213458 U.S. 176 (1982).

${ }^{214}$ Id. at 198-99, 200-01 (citing Education for All Handicapped Children Act of 1975, Pub. L. No. 94-142, 89 Stat. 773 (1975)). The legislation is now called The Individuals with Disabilities Education Act, Pub. L. No. 102-119, 105 Stat. 587 (1991) (codified as amended at 20 U.S.C. $\$ \S 1400-1461(2000))$.

${ }^{215} 473$ U.S. 432 (1985).

${ }^{216}$ Zoning permits were also required for people with mental illness or addictions 
tice White's majority opinion recognized that "requiring the permit in this case appears to us to rest on an irrational prejudice against the mentally retarded, ${ }^{217}$ the Court determined that there should be no general presumption that legislative action employing the disability classification makes unconstitutional distinctions regarding their treatment, even if such legislation systematically disadvantages individuals who fall within the classification. ${ }^{218}$ Thus, according to the Cleburne majority, statutory provisions that limit the opportunities of mentally disabled individuals are perceived as being rationally related not only to an impartial state interest, but also to the interests of those who will be deprived through its action. ${ }^{29}$

Post-ADA Supreme Court rulings likewise demonstrate that the Justices continue to subscribe to the notion that disability-based rights differ in kind from more traditional civil rights, are contingent on humanitarian concerns rather than equality, and are thus subject to the availability of competing resources. ${ }^{220}$ In Board of Trustees of Univer-

but not for housing the same number of unrelated, unimpaired people in a boarding house, apartment, fraternity house, or convalescent home. Id. at 446-47. But see Marcia Pearce Burgdorf \& Robert Burgdorf, Jr., A History of Unequal Treatment: The Qualifications of Handicapped Persons as a "Suspect Class" Under the Equal Protection Clause, 15 SANTA CLARA L. REV. 855, 902 (1975) ("As a class repeatedly abused and neglected by society and its public officials and institutions, handicapped persons have a legitimate claim for special judicial solicitude under the equal protection clause."). When drafting the ADA, Congress attempted to rebut the Supreme Court's Cleburne doctrine by creating a heightened level of statutory scrutiny. It did so, first, by including a detailed legislative history of the repressed position that people with disabilities have historically held, and second, by using the then-operative language for indicating heightened scrutiny. Nevertheless, because Congress was inartful in drafting the statute, it failed in this purpose. Silvers \& Stein, Standing at the Crossroads, supra note 100, at 102. See generally LAURENCE H. TRIBE, AMERICAN CONSTITUTIONAL LAW 991-1136 (2d ed. 1978) (describing differing levels of scrutiny).

${ }^{217}$ City of Clebume, 473 U.S. at 450.

${ }^{218}$ Id. at 446.

${ }^{219}$ See Silvers \& Stein, Chill Wind, supra note 100 (arguing that the Court's attitudes toward the disabled and states' rational interests in legislation restricting the rights of the disabled are throwbacks to patronizing attitudes towards African Americans); Silvers \& Stein, Standing at the Crossroads, supra note 100 (portraying how the Court's attitudes toward the disabled are driven more by legislative definitions and findings than by "open-minded empirical study").

${ }^{220}$ Legal scholars differ on whether communal institutions can, in fact, express attitudes. Compare Elizabeth S. Anderson \& Richard H. Pildes, Expressive Theories of Law: A General Restatement, 148 U. PA. L. REV. 1503, 1520-27 (2000) (believing collective entities capable of such expression), with Matthew D. Adler, Expressive Theories of Law: A Skeptical Overview, 148 U. PA. L. REV. 1363, 1389 (2000) (averring the opposite). I agree with Susan Bandes that the values expressed in the Court's opinions "are both a product of and an expression of certain emotional assumptions and commitments." Susan Bandes, Fear and Degradation in Alabama: The Emotional Subtext of Uni- 
sity of Alabama v. Garrett, ${ }^{221}$ Patricia Garrett sued the University after having been demoted from her position of nursing supervisor to a lower-paying job because she had undergone treatment for breast cancer. ${ }^{222}$ The Supreme Court did not reach the merits of her claim. ${ }^{223}$ Rather, the Court ruled that as a state actor the defendant was protected by the Eleventh Amendment and thus immune from Garrett's private $\mathrm{ADA}$ suit for monetary damages. ${ }^{224}$ In reaching this decision,

versity of Alabama v. Garrett, 5 U. PA. J. CONST. L. 520, 521 (2003); see also Susan Bandes, Empathy, Narrative, and Victim Impact Statements, 63 U. CHI. L. REV. 361, 366-82 (1996) (maintaining that emotional presumptions underlie juridical action). Of course, it is possible to divine many different themes running through any area of the Court's jurisprudence. The academic literature on the Supreme Court's ADA jurisprudence, to take just one example, can be organized into three broad categories that explore the (1) disharmony between the ADA's stated goals and its practical effects; (2) discomfort of the Justices about the group of people legislated as "disabled" and the effect that has upon application of the ADA; and (3) underlying principles the Justices seek to achieve as well as the goals the ADA ought to effectuate. Stein, supra note 13, at 623-26. Much ink has been, and will continue to be, spilled on this issue.

531 U.S. 356 (2001).

${ }^{222}$ Id. at 362 . Garrett's case was consolidated with that of prison guard Milton Ash, an asthmatic whose physician recommended that he not be assigned to work in areas polluted with cigarette smoke or to drive cars with carbon monoxide leaking into the interior compartment. Id. at 363.

${ }^{223}$ Id. at 362 n.2. Parenthetically, the Court did not contest Garrett's classification as a person with a disability, despite her claim not to have functional impairment. This is unusual in light of the Court's prior line of decisions denying $\mathrm{ADA}$ protection on coverage grounds, either because the plaintiffs were functionally capable or could have mitigated their impairments. See, e.g., Toyota Motor Mfg. v. Williams, 534 U.S. 184, 198, 202 (2001) (holding that an employee with carpal tunnel syndrome who was unable to perform a repetitive job function at a car manufacturing plant was not disabled enough to qualify for protection under the ADA because she was able to perform normal household chores); Sutton v. United Air Lines, Inc., 527 U.S. 471, 489 (1999) (holding that severely myopic twins who were precluded from positions as global airline pilots were not disabled within the meaning of the ADA because they were not "substantially limited in any major life activity"); Murphy v. United Parcel Serv., Inc., 527 U.S. 516, 520 (1999) (same for a mechanic with high blood pressure); Albertson's, Inc. v. Kirkingburg, 527 U.S. 555, 563-66 (1999) (same for driver with monocular vision).

The holding restricts only Title I claims for monetary damages brought in federal court by state employees or applicants for state employment against state actors. Suits against the same state actors for injunctive relief are not affected. Garrett, 531 U.S. at 360,374 n.9. Moreover, claims for money damages can still be brought in federal court by federal government agencies (such as the EEOC) on behalf of state applicants or employees, or in state courts by aggrieved persons themselves, so long as the state in which the suit is brought has consented to being sued in cases of this type. See generally Judith Olans Brown \& Wendy E. Parmet, The Imperial Sovereign: Sovereign Immunity and the ADA, 35 U. MICH. J.L. REFORM 1 (2001) (discussing the Court's doctrine of state sovereign immunity from suit under the ADA after Garrett). Most recently, in Tennessee v. Lane, 124 S. Ct. 1978 (2004), the Court held that states lack sovereign immunity from suit for ADA Title II claims. Id. at 1983-84. That case was not an 
however, the twin tenets of the canonical framework were invoked. Chief Justice Rehnquist's majority opinion stated that state workplace practices that unquestionably discriminate against people with disabilities for economic reasons are constitutional. ${ }^{225}$ This is because "it would be entirely rational ... for [state employers] to conserve scarce financial resources by hiring employees who are able to use existing facilities" rather than accede to ADA requests. ${ }^{226}$ Hence, state actors "could quite hardheadedly-and perhaps hardheartedly-hold to jobqualification requirements which do not make allowance for the disabled." 227 Although Patricia Garrett did not request any form of accommodation, the Chief Justice characterized her ADA claims as being for "special accommodations." concurred in the judgment, ${ }^{229}$ the adjudication of ADA claims was not a matter of determining equality. Rather, it required a great internal struggle between "our own human instincts" that cause us to ostracize unfamiliar types of people and "the better angels of our nature" that sympathize for "those disadvantaged by mental or physical impairments." ${ }^{230}$ Thus, according to the Court's ruling, ADA rights involve something more than equality and are motivated by pity rather than by social justice. ${ }^{231}$

employment discrimination suit, even if it did raise (inferentially) the ability of the two wheelchair-using plaintiffs to ply their legally-related trades in an inaccessible courthouse. The Chief Justice dissented, asserting that remedying the inaccessible nature of the courthouse so as to ensure access to court services was a disproportionate remedy to their systemic exclusion. This is notable for two reasons: substantively, it is a clear expression of the canonical principles as influenced by the medical model of disability; procedurally, with one additional vote, it could have comprised the majority opinion. Cf. Michael Selmi, Remedying Societal Discrimination Through the Government's Spending Power, 80 N.C. L. REv. 1575, 1575 (2002) (asserting, as a general matter, the practicality and good sense of utilizing the spending power as a means of combating discrimination).

Garrett, 531 U.S. at $369-72$

${ }^{226}$ Id. at 372 .

${ }^{227} I d$. at $367-68$.

${ }^{228}$ Id. at 368 .

${ }^{229}$ Justice Kennedy was joined by Justice O'Connor. Id. at 375 .

${ }^{230} I d$. at 375-76 (Kennedy, J., dissenting). Why Justice Kennedy (as well as the concurring Justice O'Connor) would make such a progressive statement immediately prior to skewering Title I liability against states as employers is open to conjecture. Addressing this point, Aviam Soifer argues that a majority of the Justices remain firmly unconvinced that the disabled require, or even deserve, legal protection. Aviam Soifer, Disabling the ADA: Essences, Better Angels, and Unprincipled Neutrality Claims, 44 WM. \& MARY L. REV. 1285, 1290 (2003).

${ }^{231}$ In contrast to the majority, Justice Breyer dissented on the ground that "Congress compiled a vast legislative record" that documented extensive and "powerful evidence of discriminatory treatment" of the disabled that both "implicate[d] state gov- 
The Court emphasized the distinction between antidiscrimination and accommodation, and particularly the differences between the $\mathrm{ADA}$ and other forms of accommodation, in Nevada Department of $\mathrm{Hu}$ man Resources v. Hibbs. ${ }^{232}$ Hibbs was a case brought and decided under the Family and Medical Leave Act (FMLA) ${ }^{239}$ and did not involve the ADA. Nevertheless, in upholding the right of a state employee to recover monetary damages in federal court against a state employer under that statute, the Court took care to explain that Hibbs's FMLA suit was to be treated in a manner distinct from Patricia Garrett's ADA claim. ${ }^{294}$ According to the Court, this was because the former statute was passed in an effort to eviscerate unwarranted gender discrimination and stereotyping that had kept women from enjoying employment opportunity. ${ }^{235}$ By contrast, barring people with disabilities from the workplace, at least as far as states were concerned, was rational and therefore maintainable. ${ }^{236}$ What is also notable about the Hibbs opinion is that, although the Justices correctly acknowledged the improper way women historically have been excluded from the workplace due to their socially ascribed gender roles (especially as caretakers), ${ }^{287}$ the Court characterized the FMLA as being specially protective of women. ${ }^{238}$ Though the statute is invoked to a greater degree by women than by men, ${ }^{299}$ the FMLA is a "universal mandate" that applies

ernments" and supported the rights-based theory evoked by the plaintiffs. Garrett, 531 U.S. at $377-78$ (Breyer, J., dissenting).

292538 U.S. 721 (2003).

${ }^{233}$ Pub. L. No. 103-3 (codified in scattered sections of 5 U.S.C. and 29 U.S.C.).

${ }^{234}$ Hibbs, 538 U.S. at 735 (noting that, unlike gender, disability is judged under a rational basis standard).

${ }^{235}$ Id. at 731-32. See Robert C. Post \& Reva B. Siegel, Legislative Constitutionalism and Section Five Power: Policentric Interpretation of the Family and Medical Leave Act, 112 YALE L.J. 1943, 1984 (2003) (describing the historical development of the FMLA as arising from the second wave feminist movement of the 1970s).

${ }^{236}$ Hibbs, 538 U.S. at 735.

${ }^{237}$ See, e.g., HENRY J. KAISER FAMILY FOUND., WOMEN, WORK, AND FAMILY HEALTH: A BALANCING ACT (Apr. 2003) (finding that "[a]pproximately $80 \%$ of all mothers are responsible for selecting their child's doctor, taking children to doctor's appointments, and follow-up care"), available at http://www.kff.org/womenshealth/3336index.cfm (last visited Oct. 24, 2004).

${ }^{238}$ Hibbs, 538 U.S. at 731-32.

${ }^{239}$ The Department of Labor's 2000 study reported that $58.1 \%$ of FMLA leavetakers were women. Overall, $47.2 \%$ of individuals took leave for reasons relating to their own health, $7.8 \%$ for maternity-disability reasons, $17.9 \%$ to care for a newly arrived child, and a collective $27.1 \%$ to care for an ill child, spouse or parent. U.S. DEP'T OF LABOR, BALANCING THE NEEDS OF FAMILIES AND EMPLOYERS: FAMILY AND MEDICAL LEAVE SURVEYS 2000 UPDATE, at 2-6 \& tbl.2.5, 2-8 (2001), available at http:// www.dol.gov/asp/fmla/toc.htm (last visited Nov. 30, 2004). 
equally to members of both sexes, ${ }^{240}$ hence the ability of William Hibbs to challenge the denial of unpaid leave time to care for his ailing wife. $^{241}$ Nevertheless, the Court distinguished the FMLA's role of eviscerating prejudice from that of the ADA (among other statutes regulating employer behavior), which it maintained invoked special rights. $^{242}$

More subtle than the statements above, but also supporting the canonical framework, are the omissions in two other Court opinions. Chevron U.S.A. Inc. v. Echazabal ${ }^{243}$ illustrates the difference between the Court's treatment of claims brought under Title I and Title VII. The Echazabal Court held that employers may exclude not only disabled workers who pose dangers to others, but also those who endanger themselves. ${ }^{244}$ In so doing, the Court explained only the potential costs (such as tort liability) that would be borne by the employer, ignoring the potential harm to the plaintiff's own health. ${ }^{245}$ This is in stark contrast to the Court of UAW v. Johnson Controls, Inc. ${ }^{246}$ which went to great lengths to explain that an employer's potential liability was not a valid consideration for precluding either workplace opportunity or autonomous health care choices for women. ${ }^{247}$

Similarly, in U.S. Airways, Inc. v. Barnett, ${ }^{248}$ the Court held that a requested ADA accommodation that conflicts with an established seniority system is usually unreasonable. ${ }^{249}$ However, an employee could endeavor to show "special circumstances" where it might be reasonable to make an exception and thereby compel an employer to provide an accommodation. ${ }^{250}$ What those circumstances entail remains unknown since the Court's ruling did not enumerate any factors that could be considered when determining the reasonableness of an ac-

24029 U.S.C. $\$ 2601$ (b) (4) (2000). See generally Rabin-Margalioth, supra note 40 , at 115-17 (differentiating between universal, antidiscrimination, and accommodation mandates).

${ }^{241}$ Hibbs, 538 U.S. at 725.

${ }^{242}$ Id. at 729-36.

${ }^{243} 536$ U.S. 73 (2002).

${ }^{244}$ Id. at 76.

245 Id. at 84.

246499 U.S. 187 (1991).

${ }^{247}$ Id. at 197-99.

${ }^{248} 535$ U.S. 391 (2002).

249 See id. at 403 . Robert Barnett injured his back handling baggage for the defendant U.S. Airways, was transferred to a then-vacant, less physically strenuous position in the airline's mailroom, and sought to remain in that position, in opposition to the airline's seniority-based system. Id. at 1521.

${ }^{250}$ Id. at $405-06$. 
commodation. ${ }^{251}$ Moreover, the Court neither acknowledged nor distinguished Barnett from settled Title VII jurisprudence wherein seniority systems that artificially exclude members of protected classes are examined and altered. ${ }^{252}$ That the Court elided an ADA accommodation request from such investigation demonstrates how different the Justices believe the ADA is from Title VII. ${ }^{253}$

Finally, it bears noting that in Cleveland v. Policy Management Systems Corp., ${ }^{254}$ plaintiff Cleveland was deemed to have ADA protection in retaining employment, even though she had exercised a statutory entitlement to Social Security Disability Insurance (SSDI) benefits. ${ }^{25}$ However, the burden shifted to her to show that with reasonable accommodation she could overcome the crucial aspects of the employment-related dysfunction on which her SSDI application was based. ${ }^{256}$ The Court thereby reinforced the principle that an assignment to the disability classification carries a presumption of being an inauthentic worker, and that individuals so classified were expected to prove themselves exceptions to the presumption in order to gain access to the normal opportunity range, including employment.

These Supreme Court opinions illustrate how a majority of the current Justices believe that the $\mathrm{ADA}$ differs in kind from previous civil rights statutes because it engenders special disability-specific costs for employers, bestowing more than equality upon $\mathrm{ADA}$ accommodation recipients.

\section{ADA ACCOMMODATIONS AS ANTIDISCRIMINATION}

The ADA's accommodation mandate is an appropriate antidiscrimination remedy because it corrects artificial (i.e., non-inevitable and/or easily remediable) exclusion. Title I is a reasonable remedy in that it engenders costs that are reasonable and proportionate to employers' resources. Economic and prudential justifications demon-

${ }^{251}$ See Stein, supra note 6, at 93-96.

${ }^{252}$ The litmus test is whether the seniority system is "an otherwise neutral, legitimate" one. Int'l Bhd. of Teamsters v. United States, 431 U.S. 324, 353 (1977). This, of course, begs the very question raised.

${ }^{253}$ Cf. Barnhart v. Thomas, 540 U.S. 20, 124 S. Ct. 376, 382 (2003) (holding that the Social Security Administration can promulgate a rule stating that a person is not disabled for social security purposes if she is functionally capable of some type of employment, even if the position she once held is either terminated or no longer exists in the national economy).

${ }^{254}$ 526 U.S. 795 (1999).

${ }^{255}$ Id. at $797-98$.

${ }^{256} I d$. at 798 . 
strate that, from a normative perspective, ADA accommodation costs are properly allocated to employers through antidiscrimination regulation rather than by tax-and-spend subsidies.

\section{A. An Appropriate Antidiscrimination Remedy}

The ADA's accommodation mandate is an appropriate antidiscrimination remedy because, like Title VII, the statute remedies the avoidable workplace exclusion of a targeted group. A practical example of how accommodations achieve this goal is through the application of Universal Design principles.

\section{Artificial Exclusion}

During hearings on the ADA, Congress was presented with a catalog of evidence on the historical exclusion of people with disabilities from American society. ${ }^{257}$ Among the more dramatic evidence presented were the results of an independent nationwide poll of one thousand Americans with disabilities, which found that two-thirds of working-age people with disabilities were unemployed and that almost half of those individuals wanted to work but could not do so because of employer attitudes. ${ }^{258}$ The study also found that during the year preceding the ADA hearings, nearly two-thirds of individuals with disabilities did not attend movies, three-fourths of the disabled population did not see live theater or music performances, two-thirds of disabled people had not attended sporting events, seventeen percent did not eat in restaurants, and thirteen percent had not shopped in grocery

${ }^{257}$ Congress summarized its conclusions as to this evidence in the ADA's Findings Section. 42 U.S.C. $\$ 12101$ (a) (2000). See also PELL \& BURGDORF, supra note 98, at 159 ("Historically, society has tended to isolate and segregate handicapped people. Despite some improvements, ... discrimination against handicapped persons continues to be a serious and pervasive social problem.").

${ }^{258}$ LOUis HaRris \& ASSOCS., THE INT'L CTR. FOR THE DiSABled Survey OF Disabled AMERICANS: BRINGING Disabled AMERICANS INTO THE MaINSTREAM 4751(1986) [hereinafter HARRIS/ICD SURVEY]; see Guaranteed Job Opportunity Act of 1987: Hearing on S. 777 Before the Subcomm. on Employment and Productivity and Subcomm. on the Handicapped of the Comm. on Labor E Human Res., 100th Cong., pt. 2, at 9 (1987) (statement of Humphrey Taylor, president of Lewis Harris \& Associates) [hereinafter Statement of Humphrey Taylor] quoted in S. REP. No. 101-116, at 8 (1989), also quoted in H.R. Rep. No. 101-485, pt. 2, at 31 (1990) (summarizing these results to Congress during the hearings on the ADA). For a thorough overview by one of the ADA's drafters, see Burgdorf, supra note 54, at 449-51. For a good journalistic account of the politics behind the passage of the ADA, see SHAPIRO, supra note 4, at 105-41. 
stores. ${ }^{259}$ Of course, the accuracy of these particular results, especially the employment figures, as with poll-based evidence in general, can be challenged in light of the sample size. Nevertheless, these findings were corroborated with more empirically rigorous data as well as by anecdotal evidence. ${ }^{260}$ As a result of those hearings, Congress was persuaded that the overall status of disabled people in America was a dismal one, concluding that they have historically been "relegated to a position of political powerlessness in our society" and "continually encounter various forms of discrimination." ${ }^{262}$

Consequently, the legislators found that people with disabilities have been denied equal opportunities in society, in such realms as employment, education, transportation, access to public services, and voting. ${ }^{263}$ Congress, moreover, identified the source of this exclusion as an artificial one, sustained by the "continuing existence of unfair and unnecessary discrimination and prejudice." ${ }^{264}$ Among the forms of unwarranted exclusion encountered by people with disabilities on a daily basis, Congress noted "the discriminatory effects of architectural, transportation, and communication barriers."

Accordingly, Congress premised the $\mathrm{ADA}$ on the belief that the repercussions of having a disability are often mutable and can be re-

${ }^{259}$ HARRIS/ICD SURVEY, supra note 258, at 37-38.

${ }^{260}$ For example, Census data reported at that time that more than twenty percent of working age individuals with disabilities were below the poverty level. NAT'L COUNCIL ON DISABILITY, TOWARD INDEPENDENCE 5 (1986), available at http:// www.ncd.gov/newsroom/publications/1986/toward.htm. Previous testimony before the Senate had concluded that "[b]y almost any definition . . . disabled Americans are uniquely underprivileged and disadvantaged. They are much poorer, much less well educated, and having much less social life, enjoy fewer amenities and have a lower level of life satisfaction than other Americans." Statement of Humphrey Taylor, supra note 258, at 9 . The more compelling anecdotal examples included testimony by a wheelchair-using future under-secretary of the Department of Education who was removed from an auction house for being deemed "disgusting to look at," about individuals with Down Syndrome who were banned from a zoo because of the keeper's fear they would frighten the chimpanzees, that an academically competitive and nondisruptive child was barred from attending public school because of a teacher's allegation that his physical appearance "produced a nauseating effect" upon classmates, and of the denial of a job to a competent arthritic woman by a college because of its trustees' belief that "normal students shouldn't see her." S. REP. NO. 101-116, 6-7 (1989) (citations omitted); see also Silvers \& Stein, Standing at the Crossroads, supra note 100, at 114 15.

26142 U.S.C. $\$ 12,101$ (a) (7) (2000).

262 Id. $\$ 12,101(\mathrm{a})(5)$.

${ }^{263}$ Id. $\$ 12,101(\mathrm{a})(3)$.

${ }^{264}$ Id. $\$ 12,101(\mathrm{a})(9)$ (emphasis added).

${ }^{265}$ Id. $\$ 12,101(\mathrm{a})(5)$. 
lieved when the social environment accommodates physical and cognitive difference instead of excluding it. ${ }^{266}$ Here again, legislative history shows that Congress was presented with a prodigious body of evidence which showed that being disabled led to capable citizens being denied opportunity and excluded from social participation. ${ }^{267}$ In response to avoidable exclusion, the ADA seeks to redesign society to allow the integration of disabled people, rather than to predicate inclusion on their realignment. As an expression of the social model of disability, the ADA differs both from the medical model and from the canonical view of antidiscrimination, precisely because it does not view disability-related impairments as being intrinsically disadvantageous. ${ }^{268}$

It is worth noting once more that Congress did not mandate that every requested accommodation be made for disabled workers. ${ }^{269}$ Instead, the ADA requires only the provision of reasonable and proportionately expensive accommodations, meaning those avoidable and/or easily remediable workplace exclusions referred to throughout this Article as "artificial."

By so recognizing that many disadvantages associated with disability are the results of social construct rather than biological destiny, the $\mathrm{ADA}$ helps to eliminate an environment that is unnecessarily hostile to those impairments.

266 See Silvers \& Stein, Standing at the Crossroads, supra note 100, at 89-98 (discussing the shift in the perception of women in society and contrasting with that of the disabled).

${ }^{267}$ See Timothy M. Cook, The Americans with Disabilities Act: The Move to Integration, 64 TEMP. L. REV. 393, 407-18 (1991) (exploring the history behind and implications of the ADA).

${ }_{268}$ As Silvers has aptly pointed out, the most common argument that negatively construes impairment by equating it with deficiency would describe deafness as "an intolerable deprivation" because those individuals are unable to enjoy music. Yet many people physically capable of enjoying music voluntarily do not enjoy it to the fullest extent possible. Those hearing people, however, are neither pitied for lost opportunity, nor required to defend the quality of their lives. Silvers, supra note 79, at 90; see also Harlan Hahn, Towards a Politics of Disability: Definitions, Disciplines, and Policies, SOC. SCI. J., Oct. 1985, at 87, 88-96 (noting the shift from a medical to a sociopolitical perspective of disability and its coterminous effect upon the development of antidiscrimination norms).

${ }^{269}$ See supra Part II.A.1 (explaining the ADA's limitation to only avoidable exclusion). 


\section{Universal Design}

A clear example of how accommodations remedy artificial, as opposed to natural or inherent, exclusion is the way Universal Design principles alter the physical environment. ${ }^{270}$ This architectural concept has as its tenet an approach to creating environments and products that are "usable by all people to the greatest extent possible."

Recall that a common assertion of disability rights advocates is that it is the environment, rather than a person's disability, that determines the ability of disabled people to participate in mainstream social roles. ${ }^{272}$ They argue that because our physical surroundings are structured to include an idealized bodily norm, people with disabilities have historically been excluded from opportunity. ${ }^{273}$ Perhaps the

${ }^{270}$ For discussions confined to the disability-specific context, see SELWYN Goldsmith, UnIVERSAL DESIGN: A MANUAL of PraCtical GUIDANCE FOR ARCHITECTS (2000); RoB ImRIe, Property DYNAmics and the Multiple Design Needs of Disabled PeOPle (Dep't of Geography, Royal Holloway, Univ. of London, Disability, Planning, and the Built Environment Project Paper No. 10 1999); RoB IMRIE \& PeTER Hall, INClusive Design: Designing and Developing ACCESSible ENvironments (2001). Less obvious is the related ameliorative impact that changes in physical design have on exclusionary methods of job structuring and administration.

${ }^{271}$ Ronald L. Mace et al., Accessible Environments: Toward Universal Design, in DESIGN INTERVENTIONS: TOWARD A MORE Humane ARCHITECTURE 155, 156 (Wolfgang F.E. Prieser et al. eds., 1991).

See supra Part II.A.1 (explaining the "social" or "minority" model of disability); see also DEBORAH A. STONE, THE DiSABLED STATE 117 (1984) (recommending greater scrutiny of "how particular [disability] constructs and measures systematically exclude certain understandings and include others, how they serve the political interests of some groups at the expense of others, and how they work to produce particular types of policy results"); Hahn, supra note 100, at 173-75 (claiming that features of the constructed environment "represent conscious choices" based on "bodily traits" that form the basis for discrimination based on "labeling").

${ }^{273}$ See, e.g., PELl \& BURGDORF, supra note 98, at 93 ("Structuring society's tasks and activities on the basis of assumptions about the normal ways of doing things reflects the idea that there are 'normal' people who can participate and there are people with physical and mental handicaps who cannot."); WENDELL, supra note 73, at 40 ("Much architecture has been planned with a young adult, non-disabled male paradigm of humanity in mind."); Chai R. Feldblum, Antidiscrimination Requirements of the $A D A$, in IMPLEMENTING THE AMERICANS WITH DISABILITIES ACT: RIGHTS AND RESPONSIBILITIES OF ALL AMERICANS 35, 36 (Lawrence O. Gostin \& Henry A. Beyer eds., 1993) (“[B]arriers to people with disabilities have been established because members of society have not historically viewed people with disabilities as part of the societal norm. Thus, no effort has been made to ensure that barriers to people with disabilities are not built into the structural frameworks of society."); $c$ f. Harlan Hahn, Civil Rights for Disabled Americans: The Foundation of a Political Agenda, in IMAGES OF THE DISABLED, DiSABling IMAGES 181, 184 (Alan Gartner \& Tom Joe eds., 1987) (arguing that "all aspects of the external world-including architecture, communications, and social organizations-are shaped by public policy and that policies are a reflection of pervasive 
strongest version of this assertion is articulated by feminist and disability rights advocate Susan Wendell, who avers that "the entire physical and social organization of life" has been created with the belief that "everyone [was] physically strong, as though all bodies were shaped the same, as though everyone could walk, hear, and see well, as though everyone could work and play at a pace that is not compatible with any kind of illness or pain.,274 By contrast, in a society utilizing Universal Design criteria:

a person who cannot walk would not be disabled, because every major kind of activity that is accessible to someone who can walk would be accessible to someone who cannot, and likewise with seeing, hearing, speaking, moving one's arms, working for long stretches of time without rest, and many other physical and mental functions. ${ }^{275}$

Wendell's point, although valid (as is Silvers's earlier characterization of disabled exclusion as artificial exclusion), ${ }^{276}$ should similarly not be overstated. Not every aspect of disability-based exclusion is created by the environment, nor is every exclusion from the mainstream the result of an artificial social convention. There are some people with disabilities for whom even a broad expansion of what comprises the bodily norm will not guarantee their inclusion. And among these individuals, only those whose accommodation costs are reasonable are statutorily remediable.

Nevertheless, many (even, arguably, most) disability-related exclusions from social participation based on the design of the physical environment are indeed artificial. ${ }^{277}$ At the very least, the impact of the

cultural values and attitudes," one of which is "widespread aversion to the presence of disabled individuals"); Earl D. McBride, Concept of Disability, ClinICAL ORTHOPAEDICS \& RELATED RES., Aug. 1987, at 3, 5 ("The terms 'normal,' 'physically fit,' and 'non-disabled' do not denote statistical standards. They represent value judgments in which we use ourselves as the standard and the subject of our attention as the deviation from that standard.").

${ }^{274}$ WENDELL, supra note 73 , at 39.

${ }^{275}$ Id. at 55; accord Simi Litvak \& Alexandra Enders, Support Systems: The Interface Between Individuals and Environments, in HANDBOOK, supra note 71, at 711 (enhancing the argument that disability is contingent on environment by demonstrating how support systems, including personal care assistants, improve individuals' functional capabilities in any environment).

${ }^{276}$ See supra Part II.A.1 (summarizing and evaluating Silvers's argument).

277 By extension, an argument can be made that we also order and construct society according to conceptions of ordinary working hours, the working week, and even standardized time. See generally CLARK BLAISE, TIME LORD: SIR SANDFORD FLEMING AND THE CREATION OF STANDARD TIME (2000) (describing the way western time came to be made uniform during the course of the nineteenth century); PRICE WATERHOUSE, DOING BUSINESS IN BAHRAIN 11-13 (Price Waterhouse Guides, 1996) (putting 
environment-how it is constructed, and from whose perspectivehas to be acknowledged in order to assess the inevitability of limitations. ${ }^{278}$ Notably, although the inclusive nature of Universal Design extends beyond disability (for example, to the design of new public venues with a higher proportion of toilets allocated to women than to men) ${ }^{279}$ the concept is frequently described as a disability-specific issue, and thus one more instance of invoked special rights. ${ }^{280}$ In this respect, Universal Design is similar to a number of other technological developments that originally were developed to assist people with disabilities, but which have become useful to the general population. ${ }^{281}$ Examples include the telephone, ${ }^{282}$ the typewriter, ${ }^{283}$ the Ja-

travelers on notice regarding the closure of businesses on Fridays for Islamic observance); Thomas Riis, Analysis of Working Hours, 149 DIOGENES 65, 65-85 (1990) (describing the evolution of standardized time and the variations, including hours in a day and working days in a year, that have developed in synchrony with social patterns).

${ }^{278}$ See WENDELL, supra note 73, at 45 ("We need to acknowledge that social justice and cultural change can eliminate a great deal of disability while recognizing that there may be much suffering and limitation that they cannot fix."); Harlan Hahn, Disability Policy and the Problem of Discrimination, 28 AM. BEHAV. SCIENTIST 293, 303 (1985) (arguing for "an environment designed to meet the needs of everyone, that does not contain any implicit prerequisite concerning the capacities necessary to survive or to engage in social life."). A strong application of this assertion would have every hearing person learning to sign, which although not unprecedented, is unusual. Cf. NORA Ellen Groce, Everyone Here Spoke Sign language: Hereditary Deafness on MARTHA'S VINEYARD 1-3 (1985) (describing a mostly-hearing community fluent in sign language).

${ }^{279}$ See, e.g., Selwyn Goldsmith, Access All Areas, ARCHITECTS' J., Mar. 15, 2001, at 42, 43-44 (asserting that Universal Design encompasses not only people with disabilities but also parents with small children and women forced to wait for public toilets). For the cultural implications of restroom allocation, which has been a source of research and advocacy by Mary Anne Case, see Changing Room? A Quick Tour of Men's and Women's Rooms in U.S. Law over the Last Decade, from the U.S. Constitution to Local Ordinances, 13 Pub. Culture 333 (2001). To this end, she maintains a survey on her University of Chicago website, at http://www.law.uchicago.edu/toiletsurvey/. In a similar vein, architect William McDonough designs buildings that are environmentally sustainable, a construct once thought either unobtainable or impracticable. Brian Dumaine, Are You Ready for the Green Revolution?, ForTune SMall BUS., Dec. 2001-Jan. 2002, at 44; Roger Rosenblatt, William McDonough: The Man Who Wants Buildings to Love Kids, TiME, Feb. 22, 1999, at 70.

${ }^{280}$ For examples of insistence that Universal Design is not to be disabled-specific, see Selwyn Goldsmith, Designing for the Disabled: The New Paradigm, at vi (1997); Robert ImRIE, Disability and THE City: InTERnational Perspectives (1996).

${ }^{281}$ See generally Heidi M. Berven \& Peter David Blanck, The Economics of the Americans with Disabilities Act Part II-Patents and Innovations in Assistive Technology, 12 NoTRE DAME J.L. ETHICS \& PUB. POL'Y 9, 85-89 (1998) (illustrating the economic benefit of the wider application of technology conventionally believed to be strictly limited to use for individuals with disabilities). 
cuzzi, $^{284}$ and closed-captioning. ${ }^{285}$ The construction of an inclusive environment not only provides the disabled with a means of equal participation, but also affords greater access for people without disabilities. ${ }^{286}$

To illustrate the effect of Universal Design on the inclusion of both disabled and nondisabled persons, assume that Phoebe, who has suffered a traumatic brain injury, ${ }^{287}$ wishes to work as a tax preparation expert at H\&R Shlock (H\&R). The essential job requirements are facility with basic accounting principles, ability to work long hours during the months surrounding the national filing deadline, and verbal and social skills sufficient to interview and develop a rapport with clients. Suppose as well that Phoebe is a certified public accountant, that little in life accords her more pleasure than interacting with a calculator for extensive periods of time, and that she nonetheless has an engaging personality. However, H\&R's client interviewing area is at the back of the office and up a flight of stairs, which Phoebe has difficulty negotiating because of her poor balance. ${ }^{288}$ Consequently, after

282 See AN ENCYClopaedia OF THE History OF TECHNOlOgY 719 (Ian McNeil ed. 1990) (attributing the invention of the telephone by Alexander Graham Bell as the result of him "as a teacher trying to find better ways to teach deaf students to speak").

${ }^{283}$ See EDWARD TENNER, OUR OWN DEVICES: THE PAST AND FutURE OF BODY TECHNOLOGY 193 (2003) (describing Charles Thurber's invention of a forerunner of the typewriter as a means of assisting those who could not write with a pen).

${ }^{284}$ See Harvey Skolnick, Test Your Marketing Knowledge, TORONTO STAR, Sept. 1, 1991, at F1 (reporting that the "famous whirlpool" was developed by a father seeking relief for his son with rheumatoid arthritis).

${ }^{285}$ See Stephanie Argy, Bamathan Opened Doors with Closed Captions, VARIETY, Nov. 29, 1998, at A8 (describing the inventions of Julius Barnathan, among them closedcaptioning for the hearing impaired). Conversely, accommodations routinely bestowed on nondisabled people, such as providing chairs to sit upon, are not seen as special forms of advantage. Hahn, supra note 72, at 104; see also Ball, supra note 36 , at 645-46 (pointing out that people who are dependent on communal resources, such as police protection, are not stigmatized for their dependency).

${ }^{286}$ This point is illustrated with numerous examples in GARY MOULTON ET AL., ACCESSIBLE TECHNOLOGY IN TODAY'S BUSINESS (2002).

${ }^{287}$ This condition has many pathologies, ranging from the congenital to contemporary causes. Among adults, automotive accidents are a common cause. See generally DOE Assistance to States for the Education of Children With Disabilities, 34 C.F.R. $\$$ 300.7 (c) (12) (2004) (defining traumatic brain injury); NAT'L INST. OF NEUROLOGICAL Disorders \& STROKE, TRAUMATIC BRAIN INJURY: HOPE THROUGH RESEARCH (2002) (providing information on the causes and manifestations of traumatic brain injury), available at http://www.ninds.nih.gov/health_and_medical/pubs/TBI.pdf (last accessed Nov. 2, 2004).

${ }^{288}$ See generally Cynthia M. Zablotny et al., Comparison Between Successful and Failed Sit-to-Stand Trials of a Patient After Traumatic Brain Injury, 84 ARCHIVES OF PHYSICAL MED. \& REHABILITATION 1721 (2003) (assessing the efficacy of rehabilitation treatments for 
being offered a position, Phoebe notifies H\&R of her visibly indiscernible disability ${ }^{289}$ and requests as an accommodation that she be allowed to meet with clients at some alternative location on the ground floor of the office. ${ }^{290}$

The initial argument for Universal Design in this circumstance is that had H\&R's office been built in an inclusive manner, without stairs, Phoebe would not have needed to request an accommodation in the form of an alternative meeting venue. Moreover, the disability rights advocate would point out, it is the unnecessary incorporation of stairs into H\&R's office that has engendered an artificial barrier to Phoebe's full and unaided participation as a tax preparer. ${ }^{291}$ Further, although in this hypothetical it is Phoebe who questions the necessity

traumatic brain injury patients with difficulty standing due to balance impairments).

${ }^{289}$ Pursuant to Title I, employers cannot inquire into the history, existence, or extent of a person's disability, unless the inquiry is "job-related and consistent with business necessity." 42 U.S.C. $\$ 12,112$ (d) (4) (2000). However, when a person has a disability that is not readily ascertainable and does not disclose the existence of her disability to her employer, she will not be protected under the ADA's auspices. See 42 U.S.C. $\$ 12,112$ (a) (5) (requiring "reasonable accommodations to the known physical or mental limitations of an otherwise qualified individual with a disability"). Much as, under Title VII, if a person's religious convictions prevent her from performing her employment, she is not protected unless she had previously disclosed that limitation. See, e.g., Johnson v. Angelica Unif. Group, Inc., 762 F.2d 671, 673 (8th Cir. 1985) (denying recourse to an employee who was terminated for missing work on religious holidays because she had not informed her employer of the holidays). This raises a very interesting (but secondary) issue relating to individuals with nondiscernable disabilities that I have not seen addressed in the literature. Verkerke analyzes the circumstance of a not-readily-knowable disability in the context of what happens when that nondiscernable impairment prevents the employee from fulfilling her essential job functions ("mismatching") and discusses the implications for her firing ("churning") and possible exclusion from similar future employment ("scarring"). J.H. Verkerke, Is the ADA Efficient?, 50 UCLA L. REV. 903, 910-23 (2003). Two related issues remain unaddressed. First, for the purposes of enculturating within a firm and avoiding prejudice, when should a person with a nonvisible disability disclose that disability? This is an especially pertinent question if the disability is an episodic one and/or a mental disability that is likely to encounter strong prejudice. See generally SUSAN STEFAN, Hollow Promises: Employment Discrimination Against PeOPle with Mental DisABILITIES (2002) (examining the implications of the ADA for persons with mental disabilities). Second, does the notion of constructive notice, which is not universally accepted as case law in the Title VII context, extend to disability discrimination?

See 42 U.S.C. $\$ 12,111$ (9)(B) (2000) (allowing job restructuring, equipment modification, variation in existing methods of administration, and the provision of readers or interpreters).

${ }^{291}$ The barrier would be characterized as artificial because there was no intrinsic reason for H\&R's office to include a second level. By contrast, if the structure was in Papua, New Guinea, where stilt houses are necessary to avoid tidal damage, that would alter the imperative. See generally PAUl OlIVER, DWEllings: THE House ACross THE WORLD (1987). 
of stairs in the workplace, one could imagine clients who equally dislike climbing the stairs. These could include both clients with disabilities $^{292}$ and those without disabilities who are overweight, elderly, suffering from a variety of health-related impairments, caring for small children or animals, or merely burdened with packages. ${ }^{293}$

\section{B. A Reasonable Antidiscrimination Remedy}

The ADA's accommodation mandate is a reasonable antidiscrimination remedy both because the costs it invokes are circumscribed and because it applies those expenses in a manner proportionate to the resources of the providing employers.

${ }^{292}$ This phenomenon is overlooked in the literature. Because ADA Title III requires that places of public accommodation be made readily accessible, 42 U.S.C. $\$ \S$ 12,181-12,189, some employment-related accommodation costs should be subsumed by employers in their role as owners or operators of those venues if they are otherwise ADA-compliant. However, barring suit, many venues are not readily accessible. For example, the Empire State Building complied with the ADA's regulations only after being targeted for litigation by the Department of Justice. Lindsey Gruson, Getting to Top of Empire State: Opening the Way for Disabled, N.Y. TIMES, Mar. 4, 1994, at B3. For an initial discussion of the confluence of Titles I and III, see Stein, supra note 6, at 89-90.

${ }_{293}$ I list these examples as illustrations of the principle, elaborated upon by recent Supreme Court decisions, that people can be functionally impaired without those impairments rising to the level of ADA protection. See, e.g., Toyota Motor Mfg. v. Williams, 534 U.S. 184, 202 (2002) (holding that an employee with carpal tunnel syndrome who was unable to perform repetitive job functions at a car manufacturing plant was not disabled enough to qualify for protection under the ADA because she was able to perform normal household chores); Albertson's, Inc. v. Kirkingburg, 527 U.S. 555, 562-67 (1999) (ruling that a monocular truck driver who was not rehired because he failed to meet Department of Transportation vision standards did not qualify for ADA protection, as he was able to compensate for his impairment); Murphy v. United Parcel Serv., Inc., 527 U.S. 516, 521 (1999) (ruling that a mechanic with high blood pressure did not qualify as disabled under the ADA because "when medicated, petitioner's high blood pressure [did] not substantially limit him in any major life activities"); Sutton v. United Air Lines, Inc., 527 U.S. 471, 475 (1999) (holding that severely myopic twins who were precluded from positions as global airline pilots were not considered disabled because their vision was correctable with glasses). Because it is also plausible that these same individuals could be construed as disabled within the ADA's definition, the Court's gatekeeping has been the subject of much ire from disability rights advocates. See, e.g., Burgdorf, supra note 54, at 539 ("The results in many of these decisions are manifestly inequitable and, because the constriction of the protection against discrimination is at odds with the underlying aims of the ADA and Rehabilitation Act, often illogical."); Chai R. Feldblum, Definition of Disability Under Federal Anti-Discrimination Law: What Happened? Why? And What Can We Do About It? 21 BERKELEY J. EMP. \& LAB. L. 91, 93-94 (2000) (offering "some ideas on how to get out of the convoluted mess that is the state of interpretation today regarding the definition of disability under the ADA"); Arlene Mayerson \& Matthew Diller, The Supreme Court's Nearsighted View of the ADA, in EXPLORING IMPLICATIONS, supra note 21, at 124, 125 ("When it comes to the ADA, the Court just does not 'get it."). 


\section{Reasonable Cost}

Title I requires employers to provide "reasonable" accommodations to "qualified" employees with disabilities, meaning only those individuals capable of performing the essential job functions of the respective positions sought. ${ }^{294}$ Although the statute very clearly mandates the provision of reasonable accommodations, it leaves as a "great unsettled question" the matter of precisely what can or should be considered a reasonable accommodation. ${ }^{295}$ Specifically, Title I delineates

${ }^{294}$ Thus, a blind person would certainly not be qualified to drive a truck, but she might well be a qualified molecular biochemist. See 42 U.S.C. $\$ 12,111(8)$ (2000) (defining qualified individual with respect to essential functions of the job). Statutory protection also extends to disabled workers capable of performing essential job functions without provision of reasonable accommodations, id., but those individuals are beyond the scope of this Article. For a discussion, see Stein, supra note 6 at 133 . The question of who is an individual with a disability, let alone a "qualified" one, has been the focus of much case law and legal scholarship and is likely to continue as a source of contention. For now, it suffices to say that Supreme Court holdings require disabilities to be significant ones, as measured in their mitigated states, with any attendant limitations impairing a wide range of functional activities. See, e.g., Toyota, 534 U.S. at 202 (holding that an employee with carpal tunnel syndrome who was unable to perform repetitive job functions at a car manufacturing plant was not disabled enough to qualify for protection under the ADA because she was able to perform normal household chores); Sutton, 527 U.S. at 475 (holding that severely myopic twins who were precluded from positions as global airline pilots were not disabled within the meaning of the ADA because their visual impairment was commonplace).

${ }^{295}$ Karlan \& Rutherglen, supra note 54, at 8 . Overall, reasonable accommodations encompass a wide range of individualized adjustments to existing workplace conditions but are mainly conceptualized as falling into one or both of two categories. The first category requires the alteration or provision of a physical plant, such as ramping a stair to accommodate the needs of an employee who uses a wheelchair. Accommodations of this type involve "hard" costs, meaning that they invoke readily quantifiable out-ofpocket expenses. Purchasing and installing a ramp, for example, is usually a one-time expenditure with a fixed and knowable cost. See 42 U.S.C. $\$ 12,111(9)$ (A) (2000) (requiring an employer to make "existing facilities used by employees readily accessible to and usable by individuals with disabilities"); cf. Stein, Empirical Implications, supra note 68, at 1677 (noting that most ADA studies focus on these "hard" costs). The second type of accommodation involves the alteration of the way in which a job is performed. This might mean not requiring a wheelchair-using store clerk to stack high shelves. These accommodations bring into play "soft" costs, which are more difficult to quantify. Our hypothetical employee might require a fellow worker to stack the high shelves while she staffed the register. Her circumstance might also necessitate that a human resource manager meet with other employees to explain the change in their daily duties or that a supervisor be required to learn how to take these alterations into consideration when evaluating overall job performance. See 42 U.S.C. $\S 12,111$ (9)(B) (allowing job restructuring or modification, variation in existing methods of administration, and the provision of readers or interpreters); Stein, supra note 68 , at 1677 (claiming that existing "studies do not adequately appraise 'soft' costs, including nonphysical plant expenses, such as educating human resource personnel"). For a comprehensive treatment that initiates dialogue on this topic, see Stein, supra note 6, at 
the boundary between reasonable and unreasonable as an otherwise undefined point at which a requested accommodation engenders an "undue hardship" to the providing employer. ${ }^{296}$ In determining whether a given disability-related accommodation is reasonable, interested parties are advised to take into consideration the totality of an employer's circumstances. ${ }^{297}$ Among the factors to be assessed are an employer's size, location, economic condition, and the number of people employed. ${ }^{298}$ I have addressed the implications of this formula elsewhere $;^{299}$ for now it suffices to say that Judge Posner was correct when ruling that reasonable "requires something less than the maximum possible care" as measured "in relation to the benefits of the accommodation to the disabled worker as well as to the employer's resources." ${ }^{300}$

Therefore, although the exact parameters of reasonableness are not set forth by the ADA, what is clear is that an employer is meant to incur reasonable expenses as a means of remedying workplace exclusion.

\section{Proportionate Cost}

The ADA is also a properly allocated antidiscrimination remedy because it allows employers to engender costs proportionate to their resources. Because workplace accommodations may impose an undue hardship upon employers as measured against the totality of their financial circumstances, $\mathrm{ADA}$ accommodation costs are relative rather than absolute. ${ }^{301}$ Consequently, if the same person with a disability requested identical accommodations from two different employers, the

\footnotetext{
144-78 (demonstrating how disability-related accommodations span a cost continuum ranging from the wholly efficient to the wholly inefficient and explaining what entities should bear the costs for each of these categories). Although the confluence between Title I and Title III access is incomplete, see Burgdorf, supra note 4, at 451 (discussing some of the political compromises which facilitated the ADA's passage), this is a point to which I return infra Conclusion.

${ }^{296}$ See 42 U.S.C. $\$ 12,111(10)$ (A) (2000) (defining "undue hardship" as "an action requiring significant difficulty or expense").

${ }^{297}$ These parties can include a worker with a disability seeking an accommodation, an employer considering the viability of its provision, or a court rendering a determination of reasonability in the event that a conflict arises between the two.

${ }_{298}$ See 42 U.S.C. $\$ 12,111(10)$ (B) (2000) (listing factors to be weighed in deciding "whether an accommodation would impose an undue hardship on a covered entity").

${ }^{299}$ Stein, supra note 6 , at 90.

${ }^{300}$ Vande Zande v. Wis. Dep't of Admin., 44 F.3d 538, 542-43 (7th Cir. 1995).

${ }^{301}$ See Stein, supra note 6, at $170-71$ ("[A] ccommodation costs are relative rather than absolute.").
} 
ADA might consider one request reasonable but not consider the other one to be so.

This is a calculus unique to the ADA and is caused by the statutory requirement that accommodations be reasonable as measured by the totality of a given employer's financial circumstances. ${ }^{302}$ By contrast, Title VII suits view the relative costs of bringing about a nondiscriminatory equilibrium as irrelevant, at least superficially, because by inference Title VII suits consider the absolute cost of a remedy when an employer either raises business necessity as a defense or rebuts a claimant's assertion of the existence of an alternative business practice. ${ }^{303}$ Ironically, this proscription might make some ADA accommodations relatively less costly than their contemporary Title VII counterparts. $^{304}$

A second issue raised uniquely in the $\mathrm{ADA}$ context is whether firms who either voluntarily provide accommodations or are coerced to do so through litigation will, as a result, attract additional disabled workers. According to Issacharoff and Nelson, this clustering effect is deleterious because it forces employers to repeatedly accommodate less productive workers with disabilities, driving down profits. ${ }^{305}$ As a result, employers who once accommodate a disabled worker might then be "penalized" by having more of those workers imposed into their workforce. ${ }^{306}$ But this argument only works if, empirically, concentrating workers with disabilities at particular sites will not increase the likelihood that physical plant or equipment accommodations will see repeated usage, or that an economy of scale will not ultimately bring down the cost of accommodation. ${ }^{307}$ More crucially, the reason-

${ }^{302}$ Id.; see also 42 U.S.C. $\$ 12,112$ (b) (5) (A) (2000) ("[A business must] mak[e] reasonable accommodations... unless [it] can demonstrate that the accommodation would impose an undue hardship on the operation of the business ....").

${ }^{303}$ See generally John J. Donohue III, Further Thoughts on Employment Discrimination Legislation: A Reply to Judge Posner, 136 U. PA. L. REv. 523 (1987) (arguing that Title VII is economically efficient); Thomas A. Cunniff, Note, The Price of Equal Opportunity: The Efficiency of Title VII After Hicks, 45 CASE W. RES. L. REV. 507 (1995) (analyzing the role of economic efficiency as a driving force in Title VII case law).

${ }^{304}$ The qualification reflects the fact that Title VII has been in effect thirty-six years longer than the $\mathrm{ADA}$, hence many architectural emendations may already have been carried out in the ensuing years.

${ }^{305}$ Issacharoff \& Nelson, supra note 54, at 347.

${ }^{306}$ See id. (" $[\mathrm{M}]$ ore disabled employees would 'match' with the employer who had already accommodated either through settlement or coercion ....").

${ }^{307}$ See EPSTEIN, supra note 57, at 492-94 ("The concentration of workers with specific disabilities, far from being seen as handicap ghettoization, will be regarded as a sensible effort to economize on public funds."); Verkerke, supra note 289, at 931-33 ("Whether imposing such a duty to accommodate is good public policy depends cru- 
ableness of an ADA accommodation is always determined by the totality of that particular employer's financial circumstances. ${ }^{308}$ Thus, although repeatedly imposing disability-related accommodations on a single providing employer may well reduce its profit margin per worker on each occasion, causing that employer to bear an unwanted financial obligation, whatever total reductions ensue will ultimately be curbed by an overriding standard of reasonableness. ${ }^{309}$

\section{A Properly Allocated Antidiscrimination Remedy}

Although ADA accommodations are an appropriate and a reasonable antidiscrimination device, historical exclusion from workplace opportunity can also be remedied through tax-and-spend provisions. This section argues that, for reasons of both economic efficiency and prudential propriety, $\mathrm{ADA}$ accommodations are more properly allocated as an antidiscrimination device (whose costs are borne by employers) than as a subsidy program (where the expenses are paid for by the state).

cially on ... its distributional consequences."). An important point that is tangential to this Article bears noting. When advocating in favor of the efficiency of repeated accommodations, Epstein and Verkerke each support, by inference, the notion of directed placements, meaning that they favor specific vocational placements for workers with disabilities who evidence certain skills. See EPSTEIN, supra note 57, at 493-95 (" $[F]$ ederal grants can be made to particular firms, to be spent in making their facilities accessible to certain classes of disabled persons."); Verkerke, supra note 289, at 931-33 ("Employers forced to retain comparatively less productive disabled workers suffer higher labor costs"). To the extent that this policy either limits the development of disabled workers or shunts them into certain careers, I would very strongly disagree with it and point to the parallel history among women. See, e.g., Dawn Michelle Baunach, Trends in Occupational Sex Segregation and Inequality, 1950 to 1990, 31 Soc. SCI. RES. 77, 90-93 (2002) (discussing decreasing occupational sex inequality); Jo Anne Preston, Occupational Gender Segregation: Trends and Explanations (Women at the End of the Millennium: What We Know, What We Need to Know), 39 Q. REv. ECON. \& FiN. 611, 61416 (1999) (showing substantial reduction of occupational-level gender segregation). For disabled people, these measures, even when well-intentioned, have historically resulted in sheltered workshops and make-work that demean and isolate those workers. See Weber, supra note 78, at 889-956 (cataloguing and analyzing past treatment). However, to the extent that such a policy duplicates some of the gains made in the past through vocational rehabilitation that afforded the recipients job support and options, I would endorse it. See O'BRIEN, supra note 111, at 85-86 (discussing construction of rehabilitation centers). For a more global view, see David A. Gerber, Disabled Veterans and Public Welfare Policy: Comparative and Transnational Perspectives on Western States in the Twentieth Century, 11 TRANSNAT'L L. \& CONTEMP. Probs. 77, 88-89 (2001) (discussing vocational rehabilitation of disabled World War I veterans).

${ }^{308} 42$ U.S.C. $\$ 12,111(10)$ (B) (2000).

${ }^{309}$ Id. $\$ 12,111(9)-(10)$. 


\section{Policy Choices}

Policymakers considering how to rectify historical inequities, whether motivated by reasons of equality or by a desire to redistribute social resources, usually choose between the options of regulation (for example, antidiscrimination legislation) and tax-and-spend (i.e., subsidy) programs. ${ }^{310}$ This choice is also recognized in the canonical literature examining ADA accommodations. Several commentators have advocated for subsidies in lieu of Title I's mandates as a way of providing employers with incentives to accommodate and retain workers with disabilities. ${ }^{311}$ Additional options which go beyond the scope of this Article include abrogating the ADA and reverting to an unregulated or "natural" market equilibrium, ${ }^{312}$ amending some of the

${ }^{310}$ See KeLMAN, STRATEGY OR PRINCIPLE, supra note 24, at 85-94 (discussing the use of regulations and taxes); Robert Howse, Retrenchment, Reform or Revolution?: The Shift to Incentives and the Future of the Regulatory State, in REGULATION, ECONOMICS AND THE LAW 259 (Anthony I. Ogus ed., 2001) (exploring the alternatives of regulation and incentives); Cass R. Sunstein, The Functions of Regulatory Statutes, in REGULATION, ECONOMICS AND THE LAW, supra at 3 (exploring the nature and uses of regulatory statutes). Kelman also discusses the possibility of exacting user fees from individuals who receive certain services to preserve the availability of these services for nonusers. See KELMAN, STRATEGY OR PRINCIPLE, supra note 24, at 84 ("[When] the government chooses to employ user fees, third parties always gain from the use. If third parties benefit, of course, the actor's decision to forgo the purchase of the government's service may be privately rational but socially undesirable...."). Within the ADA context, such a scheme would require workers with disabilities who benefited as the result of subsidies paid to their employers to pay a tax on those subsidies to support future subsidies. He does not address this last option, probably because these subsidies do not currently exist. Overall, Kelman is agnostic as between regulation and tax-and-spend programs as vehicles for social change. See $i d$. at 88 . Issacharoff and Nelson are equally agnostic, but they take umbrage at redistribution masquerading as equality. See Issacharoff \& Nelson, supra note 54, at 536 (lauding "Kelman's discomfort with redistribution masquerading as entitlement or antidiscrimination").

S11 See, e.g., EPSTEIN, supra note 57, at 486-88 (criticizing the ADA as economically inefficient); Schwab \& Willborn, supra note 54, at 1278-79 (arguing for an extension of the $\mathrm{ADA}$ by allowing disabled employees to pay for their extra-reasonable accommodations); Sue A. Krenek, Note, Beyond Reasonable Accommodation, 72 TEX. L. REV. 1969, 2009-13 (1994) (proposing to effectuate accommodations through a public-private partnership wherein private employers pay for most permanent, site-specific improvements to their physical plants and the federal government pays for the rest); Scott A. Moss \& Daniel A. Malin, Note, Public Funding for Disability Accommodations: A Rational Solution to Rational Discrimination and the Disabilities of the ADA, 33 HARV. C.R.-C.L. L. REV. 197, 219-20 (1998) (arguing for a grant system to federally fund reasonable disability accommodation in the workplace).

${ }_{\text {s12 }}$ The suggestion, not surprisingly, originates with Epstein who also advocates for eliminating all antidiscrimination legislation because such statutes restrict free markets. EPSTEIN, supra note 57, at 494, 505.

[Epstein's solution, however,] would only sanction and perpetuate the same irrational biases the ADA was designed to correct. This is true for a number 
statute's provisions (especially its definition of disability), ${ }^{319}$ and providing subsidies for per se unreasonable accommodations when it is socially beneficial to retain disabled people in the workplace rather than on social welfare programs. ${ }^{314}$

The general economic efficiency and prudential propriety of both regulation and tax-and-spend programs form part of an old debate

of reasons. First, labor markets have never been demonstrated, either empirically or anecdotally, to have acted rationally with regard to nonmajority group members. Hence, no evidence supports Epstein's notion that eliminating an antidiscrimination norm will yield greater rationality to the employment sphere. Second, labor markets do not function nearly as well as other markets, such as capital markets, where information is freely disseminated, as well as systemically disclosed, through governmentally enforced regulations. This is particularly certain with regard to a market failure in which the costs of including people with disabilities in a workforce are perceived as being greater than they really are. Third, applying the neoclassical economic model conceivably would compel disabled workers to underbid the value of their services in order to subsidize workplace accommodations, whether of a hard or soft variety. As a result, the disabled would be discouraged from investing in their own human capital and be further segregated from mainstream society. In sum, eliminating the ADA would only promote irrationalities that already exist in the employment decisionmaking process.

Stein, supra note 68 , at 1682-83 (footnotes omitted).

${ }^{313}$ For example, Hoffman, supra note 54, at 1271-76, proposes amending the scope of coverage so that the protected class more closely resembles the type of minority classifications utilized in other civil rights areas. Id. See also Steven B. Epstein, In Search of A Bright Line: Determining When an Employer's Financial Hardship Becomes "Undue" Under the Americans with Disabilities Act, 48 VAND. L. REv. 391, 452-53 (1995) (advocating for a definite fixed-sum cost for accommodation); Lisa A. Sciallo, Note, The ADA through the Looking Glass, 68 BROOK. L. REV. 589, 605-06 (2002) (critiquing the Supreme Court's definition of disability and its impact on the application of the ADA).

${ }^{314}$ As such:

When an employer cannot profit from retaining a worker with a disability due to her accommodation cost, there still may be reason to compel that employer to accommodate the disabled worker on the ground that society in general may benefit [as a result]. $\ldots$

In this circumstance, social efficiency is measured by any net positive gain to society. Specifically captured by this policy are disabled workers who can perform productive work through the provision of unreasonable (or, extrareasonable) accommodations. Many of these individuals are from the group referred to in the economic literature as members of the "transfer" population, meaning that they are functionally capable of work (and thus avoiding welfare dependence), but do not have that opportunity. $\cdots$

[This] is an appropriate [Kaldor-Hicks efficient] departure point from which to consider state-funded employment opportunities through the payment of subsidies to employers.

Stein, supra note 6, at 175-78 (footnotes omitted). 
within the field of public finance. ${ }^{315}$ The following sections argue in favor of antidiscrimination regulation within the context of disabilityrelated accommodations.

\section{Economic Efficiency}

Economic justifications favor the use of regulations over tax-andspend subsidies in the context of disabled workers. Although a few commentators aver that regulation and tax-and-spend schemes are equally efficient devices for managing public policy, ${ }^{316}$ most scholars divide on whether regulations or tax-and-spend programs are more efficient. ${ }^{317}$

Those commentators who disfavor regulation on efficiency grounds (as opposed to, say, libertarian autonomy objections) ${ }^{318}$ argue that mandates do not actually achieve the type of redistribution that canonical scholarship attributes to the ADA. Lawrence Summers, for instance, argues that mandated benefits do not really shift wealth from employers to employees. ${ }^{319}$ Rather, he asserts that those regulations shift the accommodation costs from employers to employees by offsetting the engendered expenses through wage reduction or the

${ }^{315}$ See Howse, supra note 310, at 259-96 (exploring the alternatives of regulation and incentives). For an attack on regulation, see Roger G. Noll, Economic Perspectives on the Politics of Regulation, in REgulation, ECONOMICS AND THE LAW, supra note 310, at 35-68 (giving a broad overview of regulations, their use and effectiveness, and the motivating factors behind their implementation). For a defense of regulation, see Sunstein, supra note 310, at 3-34 (exploring the nature and uses of regulatory statutes).

316 See KELMAN, STRATEGY OR PRINCIPLE, supra note 24, at 44 ("[R] egulation and taxation are substitutes one for the other...."); Yoram Margalioth, The Many Faces of Mandates: Beyond Traditional Accommodation Mandates and Other Classic Cases, 40 SAN DIEGO L. REV. 645, 648 n.148 (2003) (finding that mandated benefits and tax-financed programs are, as an initial matter, equal in efficiency).

${ }^{317}$ Compare, e.g., Julie A. Roin, Note, Reconceptualizing Unfunded Mandates and Other Regulations, 93 Nw. U. L. REV. 351, 382 (1999) (asserting the long term efficiency of unfunded mandates relative to funded ones), with Anthony J. Vlatas, Note, An Economic Analysis of Implied Warranties of Fitness in Commercial Leases, 94 COLUM. L. REV. 658, 686 (1994) (observing that welfare laws would be inefficient from a tax-and-spend perspective).

${ }^{318}$ Perhaps the staunchest advocate is EPSTEIN, supra note 57, at 76-78, who has long advocated against any form of employment discrimination regulation for this very reason. See also RICHARD A. EPSTEIN, EQUAL OPPORTUNITY OR MORE OPPORTUNITY? THE GOOD THING ABOUT DISCRIMINATION 1-17 (2002) (updating and reiterating many of the same arguments about the economic inefficiency of antidiscrimination legislation).

Lawrence H. Summers, Some Simple Economics of Mandated Benefits, 79 AM. ECON. REv. 177, 181 (1989). 
reduction of other employee benefits. ${ }^{320}$ What Summers avers may well be true in general employment circumstances. ${ }^{321}$ Within the ADA context, however, Christine Jolls's model, measuring the effects of accommodation mandates, demonstrates that the wage level protection of disabled workers does indeed bind employers. ${ }^{322}$ Thus, Summers's theorem would not operate in the context of ADA mandated accommodations. ${ }^{323}$

Conversely, commentators advocating in favor of regulation typically do so on the two related grounds of administrative efficiency and cost spreading. ${ }^{324}$ Administrative efficiency theory holds that it is more economically expedient to coerce the activities of individual employers by the passage of a broad regulation than it is to have the government administer a detailed subsidy program. ${ }^{325}$ Anne Alstott, for ex-

${ }^{320}$ Id. at $181-82$.

${ }^{321}$ See, e.g., Margalioth, supra note 316, at 649 (asserting that some mandates, for instance those related to pension vesting and overtime pay, can have the opposite effect of reducing benefits to targeted groups).

${ }_{322}$ Jolls, supra note 40 , at 270.

${ }^{323}$ On the other hand, because Jolls posits that restrictions on employment differentials are unlikely to be binding (even as restrictions on wage differentials are likely to bind), she predicts that Title I's reasonable accommodation mandates will reduce the relative employment rate of workers with disabilities while either increasing their wage levels or leaving them unchanged. Id. at 273-81. At the end of the day, Jolls may be correct, although there is a growing body of economic literature, which both precedes and follows her work, that argues both sides of the issue regarding the cause and effect of post-ADA employment rates among disabled workers. See, e.g., THE DECLINE IN Employment of PeOple With Disabilities: A Policy Puzzie 1-10 (David C. Stapleton \& Richard V. Burkhauser eds., 2003) (publishing many of these studies). What is clear is that Jolls's work needs to be engaged, regardless of the outcome one believes more plausible.

${ }^{324}$ See, e.g., HARVEY S. ROSEN, PUBLIC FINANCE 90-96 (6th ed. 2002) (discussing the need for intervention in order to achieve economic efficiency when externalities are present in a market); David A. Dana, The Case for Unfunded Environmental Mandates, 69 S. CAL. L. REV. 1, 36 (1995) (averring the efficiency of unfunded environmental mandates); Noll, supra note 315, at 39 (giving a broad overview of regulations, their use, their effectiveness, and the motivating factors behind their implementation); Roin, supra note 317, at 382 (asserting policy reasons supporting unfunded mandates). Other reasons for supporting regulation can be political. For example, the argument has been made that because of certain social norms only one or the other method is expedient. See generally APPROACHES AND DILEMMAS IN ECONOMIC REGULATION: POlITICS, ECONOMICS AND DYNAMICS (Atle Midttun \& Eirik Svindland eds., 2001). Alternatively, two economists have argued that even an inefficient redistributive labor market policy has the benefit of preserving the constituency that it is directed towards because it creates an incentive for those targeted individuals to enter or remain in that group, thus ensuring the continuation of political power of those beneficiaries. Daron Acemoglu \& James A. Robinson, Inefficient Redistribution, 95 AM. POL. SCI. REv. 649, 649-52 (2001).

S25 Kelman, Strategy OR PRINCIPLE supra note 24, at 863-65 (discussing when 
ample, argues strongly that subsidies are ineffective because "they require sustained intervention in labor market processes that are little understood., ${ }^{326}$

Complementing this notion is the cost-spreading precept, which maintains that it is more efficient to have employers pass on their added costs to consumers through the price of their services than it is to have an unwieldy governmental agency pass on those costs to the general tax base. This is a point that Amy Wax advances within the ADA context. ${ }^{327}$ Employer-provided workplace accommodations, she argues, can improve overall social utility so long as disabled workers are able to perform the "core elements" of the job at issue. ${ }^{328}$ For even if "many disabled persons" are less productive than nondisabled ones, Wax argues that the alternative-labor market exclusion resulting in social welfare expenditures-is ultimately more expensive to society as a whole. ${ }^{329}$

An additional reason for favoring regulation over subsidy, and one that I have not seen addressed in the literature, has to do with avoiding moral hazard. ${ }^{330}$ At best, subsidies can balance existing market inefficiencies by raising the labor market participation of a targeted group towards a nondiscriminatory equilibrium. ${ }^{\$ 31}$ Subsidies them-

regulation is an appropriate remedy to group subordination); Wax, supra note 54 , at 1449-50 (discussing possible alternatives for more efficient national policy for disabled workers).

${ }^{326}$ Anne L. Alstott, Work vs. Freedom: A Liberal Challenge to Employment Subsidies, 108 YALE L.J. 967, 1019 (1999).

${ }^{327}$ See Wax, supra note 54, at 1423 (analyzing "the cost-effectiveness of the ADA"). This article continues her research cycle on welfare rights and reciprocity. See Amy $\mathbf{L}$. Wax, A Reciprocal Welfare Program, 8 VA. J. SOC. POL'Y \& L. 477, 501-09 (2001) (arguing for conditional reciprocity as an appropriate basis of social welfare policy); Amy $\mathbf{L}$. Wax, Rethinking Welfare Rights: Reciprocity Norms, Reactive Attitudes, and the Political Economy of Welfare Reform, 63 LAW \& CONTEMP. ProBs. 257, 261 (2000) (exploring the possibility and potential impact of constitutional recognition of economic welfare rights, with regard to both social insurance and need-based transfers).

${ }^{328}$ Wax, supra note 54, at 1421; see also id. at 1426 (noting that given sufficient productivity by the disabled employee, the result for society as a whole may be "net positive").

${ }^{329}$ See id. at 1423-24 (arguing that if labor markets tailored for marginal productivity force employers to hire disabled persons at excessive wages, the result may be costly for taxpayers). Nevertheless, Wax asserts that minimum wage and equal pay legislation prevent employers from hiring and retaining workers with disabilities, even though it is economically beneficial to society as a whole to do so. Id . at 1424 .

330 See New PalgRaVE: A DiCTIONARY OF ECONOMiCS 549-51 (John Eatwell et al. eds., 1998) (defining and discussing the concept of a moral hazard).

${ }^{331}$ The qualification exists for two reasons. First, employers may not actually understand the relative economic value that targeted workers with subsidies achieve. 
selves will not, however, change the ingrained negative prejudices that cause those inequities to exist, nor preclude similarly inefficient practices from recurring in the event that the subsidies are discontinued. ${ }^{392}$ Moreover, tax-and-spend programs may have the negative effect of creating an incentive for employers not to hire workers from subsidized groups of their own accord, even when they are valued equally to majority members. Because denying employment to previously subsidized workers might galvanize the legislature to reissue those subsidies, savvy employers could game the system and reap windfall profits.

Finally, as John Donohue has noted, "while prohibiting employers from discriminating may be inefficient in the short run, it may be efficient in the long run." ${ }^{399}$ This is because in a discriminatory equilibrium, employers frequently rely on proxies (e.g., educational degrees or workplace experience) to make employment decisions, as an immediately efficient method of assessing ability. ${ }^{934}$ When those signals do not accurately correlate with empirical reality, equally productive workers are shut out of workplace opportunity. The result is statistical discrimination, a form of market failure that is initially caused by informational asymmetry ${ }^{335}$ and is then reinforced because information

Second, even if subsidies make targeted workers equally (or even more) profitable, and employers realize this effect, they may not want to expend administrative resources in managing the employment of those individuals when they can employ others without similar concerns. Stein, supra note 6, at 155-62.

${ }^{332}$ Id.

${ }^{339}$ Donohue, supra note 303, at 532. See also John J. Donohue III, Prohibiting Sex Discrimination in the Workplace: An Economic Perspective, 56 U. CHI. L. REV. 1337, 1347-56 (1989) (averring that civil rights laws precipitate the speed by which social exclusions are eventually, or conceivably, remedied). For arguments about the transformative value to African Americans of civil rights laws, see John J. Donohue III \& James Heckman, Continuous Versus Episodic Change: The Impact of Civil Rights Policy on the Economic Status of Blacks, 29 J. ECON. LITERATURE 1603, 1640-41 (1991).

${ }^{334}$ See generally Arrow, supra note 166, at 24 (noting that "[s] kin color and sex are cheap sources of information" for distinguishing between different groups of workers); Peter Norman, Statistical Discrimination and Efficiency, 70 REV. ECON. STUD. 615, 624-26 (2003) (noting that statistical discrimination is more efficient than individualized discrimination when the increased investment cost outstrips the informational gains).

${ }_{335}$ "Statistical discrimination occurs when two groups vary on average in terms of some relevant characteristic, and an employer treats all members of each group as if they all possess that average characteristic." Katherine V.W. Stone, The New Psychological Contract: Implications of the Changing Workplace for Labor and Employment Law, 48 UCLA L. REV. 519, 599 (2001). "For example, if employers assume women will have short job tenure and treat all women on the basis of that belief, then employers will avoid hiring women for jobs requiring longevity." Id. at 599-600. This type of discrimination was best evidenced in the internal labor markets of the twentieth century. Id. Most commentators consider statistical discrimination to be a market failure and 
itself costs something to acquire. ${ }^{396}$ Yet, forcing employers to act inefficiently, that is, requiring them to expend sums to gather information about particular workers, can benefit those employers in the long run, even if it incurs inefficient short-term costs. ${ }^{33}$

In the case of workers with disabilities, employers are sometimes ignorant of the actual costs and benefits of accommodations. ${ }^{338}$ Thus, an employer may overestimate the cost of an accommodation, may not be familiar with the potential benefits and costs that are associated with providing accommodations, or may include unsubstantiated costs

an inefficient event. See, e.g., David Charny \& G. Mitu Gulati, Efficiency-Wages, Tournaments, and Discrimination: A Theory of Employment Discrimination Law for "High-Level" Jobs, 33 HARV. C.R.-C.L. L. REV. 57, 63-66 (1998) (arguing that statistical discrimination results in inefficient job assignments and "reduces incentives for its victims to acquire human capital"); Kelman, Job Testing, supra note 27 at 1204-05 (contending that general ability job tests have very low statistical validity and are therefore discriminatory); Richard H. McAdams, Cooperation and Conflict: The Economics of Group Status Production and Race Discrimination, 108 HARV. L. REv. 1003, 1074-78 (1995) (pointing out that the deadweight loss of race discrimination consists of material sacrifices made by the original discriminators to lower the status of the victim and the investments made by the original discriminators).

${ }^{336}$ Since the 1960 s, economists have recognized the importance of information when modifying pre-existing economic models. The seminal article is by George J. Stigler, The Economics of Information, $69 \mathrm{~J}$. POL. ECON. 213 (1961), in which he analyzes economic organization in light of the search for information. As such, real-world results may differ from those that academic economists observe under a perfect competition framework, such as the one put forward in the neoclassical model, precisely because information costs something to acquire. Moreover, the perfect competition model (and its assumptions) is better reserved for addressing a firm's pricing and output decisions instead of its input-purchasing decisions. There also are some departures from perfect competition, e.g., product differentiation, that really have no impact on this analysis. Hence, business practices that may seem inexplicable in a world with perfect competition assumptions suddenly become explicable. RONALD H. COASE, THE FIRM, THE MARKET, AND THE LAW 13-15 (1988).

${ }^{337}$ See generally John F. Newman \& Roxan E. Dinwoodie, Impact of the Americans with Disabilities Act on Private Sector Employers, 20 J. REHABILITATION ADMIN. 3, 9 (1996) (reporting on a study of 20,000 private sector employers in Georgia, which found that employers lacked information about both the ADA and workers with disabilities).

To give just one example, a December 2002 study by the General Accounting Office (GAO) found that only a "very small proportion" of businesses utilized either the two available federal tax credits for hiring disabled workers or the barrier removal deduction, which would make their premises accessible to disabled customers (and, with some overlap, workers with disabilities). GEN. ACCOUNTING OFFICE, BUSINESS TAX INCENTIVES: INCENTIVES TO EMPLOY WORKERS WITH DISABILITIES RECEIVE LIMITED USE AND HAVE AN UNCERTAIN IMPACT, at page preceding page i (GAO-03-39 Dec. 2002), available at http://www.gao.gov/new.items/d0339.pdf. Respectively, the two hiring incentives provide for $\$ 2,400$ per disabled employee and $\$ 5,000$ (combinable) per annum; the public accommodation credit allows for as much as $\$ 15,000$ per year. Id. 
(or benefits) when calculating productivity. ${ }^{339}$ In this circumstance, the disabled employee may be wrongly perceived as being a member of a group of individuals that, on average, are less productive than workers without disabilities. ${ }^{340}$ Although an employer could investigate whether a particular applicant has productivity above or below that of the rest of the disabled category, she will not do so to avoid information costs. Thus, the employer uses the signal of disability and ends up believing, at times incorrectly, that an individual employee is less productive than she actually is.

The ADA provides three avenues through which this information asymmetry, causing individual employers to suffer from inefficient market failures, may be cured. First, as part of assessing the reasonableness of accommodations, employers are required to engage in an "interactive process" with the disabled workers requesting those workplace alterations. ${ }^{341}$ This procedure is one that should generate the information necessary to cure an informational asymmetry caused by market failure. ${ }^{342}$ During this process, employers and employees meet

${ }^{389}$ An example from the academic literature is provided by Verkerke, supra note 289 , who believes that the reasonableness of an accommodation will vary depending on whether the job in question is high or low risk. Id. at 941-43. His argument necessarily assumes that people with disabilities are at greater risk of danger and are also less capable of protecting themselves from those hazards. This is a proposition without any basis in empirical fact, although one could plausibly interpret the Supreme Court's decision in Cherron U.S.A. Inc. v. Echazabal, 536 U.S. 73 (2002), to be in harmony with this presupposition. See id. at 76 (holding that a prospective employee who is a threat to his own safety may be denied an employment opportunity under the ADA).

${ }^{340}$ See J. HOULT VERKERKE, AN ECONOMIC DEFENSE OF DISABILITY DISCRIMINATION LAW 20-21 (University of Virginia School of Law Legal Studies Working Paper No. 9914, June 1999) (arguing that employers who rely on signals or proxies for gauging productivity run the risk of relying on data which may either be absolutely wrong or may be a statistically accurate statistical inference that is often wrong in particular cases), available at $\mathrm{http}: / /$ papers.ssrn.com/sol3/papers.cfm?abstract_id=170014.

${ }^{341} 29$ C.F.R. $\$ \S 1630.2(0)(3), 1630.9$ (2004). See, e.g., Alysa M. Barancik, Comment, Determining Reasonable Accommodations under the ADA: Why Courts Should Require Employers to Participate in an "Interactive Process," 30 LoY. U. CHI. L.J. 513, 542-45 (1999) (examining the scope of employers' participation in the interactive process); Amy Renee Brown, Note, Mental Disabilities Under the ADA: The Role of Employees and Employers in the Interactive Process, 8 WASH. U. J.L. \& POL'Y 341, 352-68 (2002) (addressing the importance of the interactive process and the need for an EEOC mandate on that process).

${ }^{342}$ One would think that profit-maximizing employers acting in their own selfinterest would have already expended resources to find out general information on positive and negative externalities. Nonetheless, although employers might have general information on these effects, they may not have particular information related to individuals with disabilities because of a lack of experience with, or exposure to, those workers. 
not only to exchange formal requests but also, equally important, to trade information and perspectives about the accommodations at issue. ${ }^{343}$ As a result, disabled workers are guaranteed a forum in which they can inform their employers what accommodations they feel they require to perform the essential job functions of their particular employment. ${ }^{344}$ In turn, employers have the opportunity to accede to these requests or to explain to those workers why the accommodations requested would engender an undue hardship. ${ }^{345}$ This interactive process is intended to be a cooperative, informational exchange rather than a confrontational process. ${ }^{346}$ Second, assuming that the interactive process does not result in a mutually acceptable solution, employees with disabilities can file disability discrimination complaints with local EEOC offices. ${ }^{37}$ Once a complaint has been filed, either

${ }^{343}$ Nor must individual employees and their employers go through the interactive process blindly or in a vacuum. Well-financed, federally-funded centers facilitate the interactive process by providing concrete accommodation options and suggestions and by informing employers about existing federal and state tax incentives and credits These government-supported facilitators include the ten regional offices of the Job Accommodation Network, available at http://www.dol.gov/odep/programs/job.htm; the Office of Disability Employment Policy, available at http://www.dol.gov/odep; and the Social Security Administration's Employment Support Program, available at http://www.ssa.gov/work. State-level equivalents also exist. For instance, the Florida Governor's Alliance for Employment of Citizens with Disabilities provides an online job bank for disabled job seekers and potential employers, including a free CD-ROM generated by the privately-funded Able Trust that profiles some 1200 college students with disabilities who are seeking internships or jobs upon graduation. The Able Trust, available at http://www.abletrust.org; The Florida Alliance for Assistive Services and Technology, available at http://www.faast.org.

${ }^{344}$ This is because the disabled worker has information about herself that may not be readily available to or knowable by the employer, and thus an exchange of information during the interactive process can add to the employer's calculus.

${ }^{345}$ The employer has greater familiarity and knowledge about the workplace and its operation and may be able to suggest less costly alternatives or other avenues toward achieving a mutually agreeable position.

${ }^{346}$ See Sam Silverman, The ADA Interactive Process: The Employer and Employee's Duty to Work Together to Identify a Reasonable Accommodation Is More Than a Game of Five Card Stud, 77 NEB. L. REV. 281, 288 (1998) ("[B]oth parties can benefit if they are willing to place all their cards on the table in an effort to determine if a reasonable accommodation can be identified.").

${ }^{347} 42$ U.S.C. $\$ 2000$ (e)(5) (2000); see 29 C.F.R. $\$ \S 1601.6-1601.14$ (2004) (establishing the guidelines for this process). These complaints can include reasons beyond failure-to-accommodate; for instance, disability harassment is a cause of action recently recognized by the Fourth and Fifth Circuits. See, e.g., Fox v. Gen. Motors Corp., 247 F.3d 169, 176 (4th Cir. 2001) ("[T] he ADA, like Title VII, creates a cause of action for hostile work environment harassment."); Flowers v. S. Reg'l Physician Servs., Inc., 247 F.3d 229, 232 (5th Cir. 2001) ("[T] he ADA embraces claims of disability-based harassment."); see also Lisa Eichhorn, Hostile Environment Actions, Title VII, and the ADA: The Limits of the Copy-and-Paste Function, 77 WASH. L. REV. 575, 577 (2002) ("[T] he circuit 
the employer or the employee can request mediation of their differences, a process which the ADA does not require but strongly encourages. ${ }^{348}$ Studies, including the EEOC's own internal report to Congress, evidence that mediation is an excellent vehicle through which to have employers and employees exchange information and perspectives. ${ }^{349}$ Mediation as a process also engenders less psychic cost and emotional damage to the employment relationship than the third option, litigation (although it is true that the filing of a discrimination complaint is unlikely to resound very well with employers). ${ }^{950}$ Third, if mediation has not proven satisfactory (or has not even transpired, because it is voluntary), those same disabled workers can sue their employers. Commencing a Title I lawsuit is the least effective, as well as the most acrimonious, means of curing an employer's market failure. In theory, the litigation of such a claim should, in the course of events, provide the means to correct flawed assumptions held by both employers and employees as to the real costs of accommodations. As a practical matter, this result is precluded by the overwhelming rate of defendant victories. ${ }^{951}$

courts began their examinations of whether hostile environment harassment could be actionable under the ADA by noting that the statute explicitly prohibits discrimination related to the 'terms, conditions, and privileges' of employment."); Holland M. Tahvonen, Note, Disability-Based Harassment: Standing and Standards for a "New" Cause of Action, 44 WM. \& MARY L. REV. 1489, 1494-95 (2003) ("[D] isability harassment as a cause of action is modeled after the Title VI harassment claim.").

${ }^{948} 42$ U.S.C. $\$ 12,212(2000)$.

${ }^{349}$ See E. Patrick McDermott et al., An Evaluation of the Equal Employment Opportunity Commission Mediation Program (Sept. 20, 2000), available at http://www.eeoc.gov /mediate/report/chapter6.html (finding "high participant satisfaction with the various elements of the EEOC mediation program"); Philip Zimmerman, The Equal Employment Opportunity Commission's Mediation Program, 71 CPA J., Mar. 2001, at 66 (acknowledging that the first year of the EEOC's voluntary mediation pilot program was "highly successful"). EEOC mediation has continued in spite of inadequate funding; although the EEOC's workload increased by over forty percent due to the addition of ADA disputes, its budget remained the same. Kathryn Moss et al., Unfunded Mandate: An Empirical Study of the Implementation of the Americans with Disabilities Act by the Equal Employment Opportunity Commission, 50 U. KAN. L. REV. 1, 19 (2001). Nonetheless, the current EEOC chair has aggressively pursued increased mediation through a "proactive prevention" program. See EEOC Chair Offers Updated Plan to Combat Discrimination, 3 EMP. DISCRIMINATION L. UPDATE, July 2002, at 6.

${ }^{350}$ The possible souring of employer-employee relations is an important point to emphasize as job reinstatement is one of the primary remedies sought by Title I plaintiffs. Cf. Ivan E. Bodensteiner \& Rosalie B. Levinson, Litigating Age and Disability Claims Against State and Local Government Employers in the New "Federalism" Era, 22 BERKELEY J. EMP. \& LAB. L. 99, 100 (2001) (explaining the difficulty of bringing civil rights claims).

${ }^{351}$ Specifically, an American Bar Association report found that employers prevailed in more than ninety-two percent of Title I cases between 1992 and 1997. Study 
Although each of these measures, in turn, carries increasingly heavy short-term transaction costs, they are collectively designed to correct long-term information asymmetry through the coerced exchange of information. The prudential propriety of ADA accommodations is discussed in the next section.

\section{Prudential Propriety}

ADA accommodations are also a properly allocated antidiscrimination remedy in that they require employers to remedy the subordinated status of disabled workers at a reasonable and proportionate cost. ${ }^{352}$ That requirement arises from an antidiscrimination mandate

Finds Employers Win Most ADA Title IJudicial and Administrative Complaints, 22 MENTAL \& PHYSICAL DisABILITY L. REP. 403, 403-04 (1998). A subsequent study of outcomes in 1998 indicates that the employers' win rate increased to ninety-three percent. Ruth Colker, The Americans with Disabilities Act: A Windfall for Defendants, 34 HARV. C.R.-C.L. L. REV. 99, 99-100 (1999). The empirical study by Colker substantiates these findings but with greater nuance, concluding that a large measure of plaintiff losses under the $\mathrm{ADA}$ are because " $[\mathrm{c}]$ ourts are abusing the summary judgment device" by "refusing to send 'normative' factual questions" to juries. Id. at 101. These results are also substantiated in the smaller sample size of the Eastern District of Pennsylvania. See Louis S. Rulli, Employment Discrimination Litigation Under the ADA from the Perspective of the Poor: Can the Promise of Title I Be Fulfilled for Low-Income Workers in the Next Decade?, 9 TEMP. POL. \& CIV. RTS. L. REV. 345, 365-75 (2000) (finding that employers won about ninetyseven percent of the Title I cases).

It bears noting that in the circumstance of actually going before a jury, the courts of appeals are divided as to which party bears the burden of proving the reasonableness of a given accommodation. For example, the D.C. Circuit places both the burden of production and of persuasion on the plaintiff. Barth v. Gelb, 2 F.3d 1180, 1186 (D.C. Cir. 1993). In contrast, the Fifth and Ninth Circuits place the burdens of proving both the unavailability of a reasonable accommodation, as well as the undue hardship that one would cause, on defendants. Mantolete v. Bolger, 767 F.2d 1416, 1423-24 (9th Cir. 1985); Prewitt v. U.S. Postal Serv., 662 F.2d 292, 308 (5th Cir. Unit A Nov. 1981). The Second Circuit takes a middle ground that alternates burdens. Borkowski v. Valley Cent. Sch. Dist., 63 F.3d 131, $137-38$ (2d Cir. 1995). Its reasoning in so doing is persuasive. The disabled plaintiff may have personal knowledge of her own disability and therefore bears the initial burden of persuasion. Id. This parallels the duty of a Title VII plaintiff after McDonnell Douglas Corp. v. Green, 411 U.S. 792, 802 (1973) ("The complainant in a Title VII trial must carry the initial burden under the statute of establishing a prima facie case of racial discrimination."). In turn "the employer has far greater access to information" regarding "its own organization and, equally importantly, about the practices and structure of the industry as a whole." Borkowski, 63 F.3d at 137. This compromise steers a wise course between the intercircuit poles in that it duplicates, through coerced circumstances, the type of informational exchange that should have happened during the earlier stages of the interactive process. This symmetry was intentional. See Burgdorf, supra note 4, passim (describing which portions of the ADA were modeled after existing civil rights provisions). islation).

${ }^{352}$ See supra Part III.B (surveying the initial regulatory interpretations of $§ 504$ leg- 
(as opposed to a subsidy) and, therefore, has moral flavor. Accordingly, as a normative matter, the $\mathrm{ADA}$ is capable of effectuating a change in societal perception towards the disabled.

By conceiving of accommodation costs as part of the process of antidiscrimination reform rather than by characterizing them as a subsidy program, Congress has sent a clear message to employers that the ADA's remedies are intended as a correction of past injustice rather than as a charitable handout. Specifically, Congress declared that the statute's main purpose was "to provide a clear and comprehensive national mandate for the elimination of discrimination against individuals with disabilities" ${ }^{\text {"353 }}$ by promulgating "clear, strong, consistent, enforceable standards addressing" both individual and systematic forms of discrimination. ${ }^{354}$ This language indicates that Congress, through passage of the ADA, desired sweeping changes in social policy. Hence, Congress's overt intention in promulgating the statute was to raise the level at which social exclusion of the disabled would be examined by courts in the future. ${ }^{355}$ Moreover, Congress used language in its legislative findings that was specifically taken from Supreme Court decisions approving equal protection classifications. ${ }^{356}$ The use of this specific language in the ADA-responding to what the Supreme Court, circa 1990, required for heightened constitutional scrutiny-demonstrates that Congress was consciously attempting to frame ADA remedies as part of an antisubordination agenda, a classic goal of civil rights law. ${ }^{357}$

${ }^{353} 42$ U.S.C. $\S 12,101$ (b) (1) (2000)

${ }^{954} I d$. at $\$ 12,101(\mathrm{~b})(2)$.

855 "The congressional findings ... serve as a useful aid for courts to discern the sorts of discrimination with which Congress was concerned." Olmstead v. L.C. ex rel. Zimring, 527 U.S. 581, 613 (1999) (Kennedy, J., concurring); see also Sutton v. United Air Lines, 527 U.S. 411, 494 (1999) (Ginsburg, J., concurring) (opining that the Findings Section affords "[ $t$ ] he strongest clues to Congress' perception of the domain of the Americans with Disabilities Act").

${ }^{356}$ See Burgdorf, supra note 4 , at 436 (noting that the finding that, inter alia, the disabled constituted a "discrete and insular minority" drew its cumbersome language from several Supreme Court decisions); Silvers \& Stein, Standing at the Crossroads, supra note 100, at 88-96 (discussing the way the Supreme Court has addressed the ADA).

${ }^{357}$ See Bagenstos, supra note 21, at 453-84 (arguing that an antisubordination approach can help give content to the ADA's broad and ambiguous definition of disability); Ruth Colker, Anti-Subordination Above All: Sex, Race, and Equal Protection, 61 N.Y.U. L. REV. 1003, 1007-10 (1986) ("iC]ourts should analyze equal protection cases from an anti-subordination perspective."(footnote omitted)); Kenneth L. Karst, Why Equality Matters, 17 GA. L. REV. 245, 247-49 (1983) (suggesting that the stigma of subordination imposed by organized society is a violation of the principle of equal citizenship); $c f$. Owen M. Fiss, Groups and the Equal Protection Clause, 5 PHIL. \& PUB. AfF. 107, 154-55 
Nevertheless, canonical scholarship typifies the ADA as a redistribution device. When so doing, Kelman correctly states that the result of framing remedial devices as a rights violation is that those empowered "will be believed to have a superior higher-priority, rights-based claim to social resources than they ought to have" as opposed to having to compete with all claimants on state resources. ${ }^{358} \mathrm{He}$ is, however, mistaken in resisting the equivalence of accommodations to race- or sex-based remedies under Title VII. ${ }^{359}$ Conversely, in contesting Kelman's conception of antidiscrimination theory, ${ }^{360}$ Samuel Bagenstos is correct in articulating an antisubordination theory for the ADA that parallels that of other group antisubordination theory. ${ }^{361} \mathrm{He}$ points out that those scholars who have articulated group-based antisubordination theory generally agree that antidiscrimination law ought to be understood as eviscerating practices of systemic subordination, ${ }^{362}$ and that eliminating those barriers to equality may provide those group members with remedies that mainstream society may not access. ${ }^{363}$ In making that argument, Bagenstos asserts that "antidiscrimination law aims at a wholesale, not a retail, injustice." ${ }^{, 64}$ As such, he maintains that the goal of statutes like the ADA is to alter the employer behavior that contributes to unacceptable systemic patterns of social and eco-

(1976) (noting the perpetual subordination of African Americans).

${ }^{358}$ KELMAN, STRATEGY OR PRINCIPLE, supra note 24, at 114.

${ }^{959}$ See Kelman, supra note 21, at 92-96.

${ }^{360}$ See Bagenstos, supra note 16, at 832 ("Kelman's argument does not withstand close scrutiny when considered on its own terms, largely because any notion of what constitutes rational discrimination must itself rest on a series of contentious normative judgments.").

${ }^{361}$ See Bagenstos, supra note 21, at 452 (explaining that he is drawing "on the work of scholars who have articulated an antisubordination theory as both a description and defense of civil rights law").

${ }_{362}$ For two recent and thoughtful variations on this theme, see Jack M. Balkin \& Reva B. Siegel, The American Civil Rights Tradition: Anticlassification or Antisubordination? 58 U. MIAMI L. REV. 9, 10 (2003) (averring that the normative goals of anticlassification and antisubordination, usually considered in opposition to each other, "overlap [in scope, and] that their application shifts over time in response to social contestation and social struggle") and Robert Post, Prejudicial Appearances: The Logic of American Antidiscrimination Law, 88 CAL. L. REV. 1, 31 (2000) (asserting that antidiscrimination law cannot eliminate stereotypes entirely but can alter and modify them).

${ }_{363}$ Bagenstos, supra note 21, at 452-57; see also Colker, supra note 357, at 1015 (asserting that state actors ought to be allowed to "use facially differentiating policies to redress subordination"); Fiss, supra note 357, at 136 (asserting that "preferential and exclusionary policies should be viewed quite differently"); Kenneth L. Karst, Paths to Belonging: The Constitution and Cultural Identity, 64 N.C. L. REv. 303, 338 (1986) ("If the subordination of a group is a constitutional wrong, there is nothing unorthodox in the suggestion that group remedies may be appropriate.").

Bagenstos, supra note 16 , at 837 . 
nomic subordination. ${ }^{365}$ This is premised on the notion that "employers who have a choice between participating in a subordinating system and working (at reasonable cost) against such a system have a moral obligation to respond in a way that reduces subordination., ${ }^{366}$

Moreover, it is precisely because Title I accommodations affect the workplace that they must be conceived of as an equalizing measure rather than as charity, or as a variety of affirmative action. The centrality of work to people's notion of self-respect and value would be difficult to overstate. ${ }^{367}$ This is equally, if not more, true of disabled people, whose historical experience in the labor market is one of exclusion and segregation. ${ }^{368}$ Furthermore, according to the "contact hypothesis," ${ }^{369}$ an extension of one of the associational arguments made in Brown $v$. Board of Education ${ }^{370}$ bias can be reduced by exposing individuals from the mainstream to members of minority groups with whom they are less familiar. ${ }^{371}$ Specifically, footnote eleven of the

${ }^{365}$ Id. at $837-39$.

366 Id. at 838 .

367 Schultz notes that:

Our historical conception of citizenship, our sense of community, and our sense that we are of value to the world all depend importantly on the work that we do for a living and how it is organized and understood by the larger society. In everyday language, we are what we do for a living.

Schultz, supra note 99, at 1884. See also JUDITH N. SHKLAR, AMERICAN CITIZENSHIP: THE QUEST FOR INCLUSION 63-101 (1991) (arguing that there is a right to work and earn, which is linked to one's standing as a citizen); Cynthia L. Estlund, Working Together: The Workplace, Civil Society, and the Law, 89 GEO. L.J. 1, 3-5 (2000) (arguing that, outside the family, the workplace is the single most important site of cooperative interaction and sociability among adult citizens).

${ }^{368}$ Gregory S. Kavka, Disability and the Right to Work, 9 SOC. PHIL. \& POL'Y 262-63 (1992); see also Elizabeth Clark Morin, Americans with Disabilities Act of 1990: Social Integration Through Employment, 40 CATH. U. L. REV. 189, 192-95 (1990) (addressing the historical treatment of people with disabilities and the importance of integrating them into the workplace); Mark C. Weber, Beyond the Americans with Disabilities Act: A $\mathrm{Na}$ tional Employment Policy for People with Disabilities, 46 BUFF. L. REV. 123, 124 (1998) (asserting that the federal government needs to implement a "national employment policy for persons with disabilities").

${ }^{369}$ The theory is said to originate with GORDON W. ALLPORT, THE NATURE OF PREJUDICE 250-67 (1954).

370 U.S. 483, 493-95 (1954). A great deal of scholarship has, unsurprisingly, examined the decision and its implications. For one recent example (because the fiftieth anniversary of the decision is certain to spur many), see ROBERT J. COTTROL ET AL., BROWN V. BOARD OF EDUCATION: CASTE, CULTURE, AND THE CONSTITUTION (2003).

${ }^{371}$ This is a standard sociological argument. For a classic expression of this theme in the context of overcoming subordination, see ERVING GOFFMAN, STIGMA: NOTES ON THE MANAGEMENT OF SPOILED IDENTITY 5 (1963). For a modern take, see CYNTHIA L. ESTLUND, WORKING TOGETHER: HOW WORKPLACE BONDS STRENGTHEN DEMOCRACY (2003). Ironically, Estlund does not include the disabled in her analysis. 
Brown opinion cites a psychological study examining children's preferences for white dolls ${ }^{372}$ that the Court found influential in determining (constitutionally-based) association rights. ${ }^{373}$ The same normative dynamic applies to people with disabilities, since similar studies on disability show that nondisabled children have an even stronger aversion to drawings depicting individuals with obvious disabilities than to drawings depicting racial-minority children. ${ }^{374}$ Thus, from a prudential perspective, it is crucial both to integrate workers with disabilities into the workplace and to ensure that such incorporation is received as a matter of right rather than as one of goodwill.

To effectively influence society towards a social norm of inclusion, disabled workplace participation must be grounded in equality theory rather than being framed as a subsidy arising from humanitarian concern. This premise can be observed by applying arguments from the emerging field of expressive law, which considers how law can influence individual behavior by altering broader social mores. ${ }^{376}$ Expressive law, which is a further evolution of the field of law and social norms $^{377}$ and behavioral economic scholarship, ${ }^{378}$ explores the ques-

${ }^{372}$ Kenneth B. Clark \& Mamie P. Clark, Racial Identification and Preference in Negro Children, in REAdINGS IN SOCIAL PSYCHOLOGY 551-60 (Guy E. Swanson et al. eds., 1952).

${ }^{373}$ Brown, 347 U.S. at 494 n.11. Naturally, not all commentators are enamored with the theory. See, e.g., Gary Blasi, Advocacy Against the Stereotype: Lessons from Cognitive Social Psychology, 49 UCLA L. REV. 1241, 1279 (2002) (reporting that the contact hypothesis "has proven wildly overoptimistic"); Krieger, supra note 203, at 1331 ("We also know that simple integration does little to reduce intergroup conflict.").

${ }^{374}$ See Norman Goodman et al., Variant Reactions to Physical Disabilities, 28 AM. SOC. REV. 429, 434-35 (1963) (discussing test results for various groups' reactions to different disabilities); Stephen A. Richardson, Age and Sex Differences in Values Towards Physical Handicaps, 11 J. HEALTH \& SOC. BEHAV. 207, 212-13 (1970) (observing shifts, based on age and gender, in reactions to different handicaps); Stephen A. Richardson \& Jacqueline Royce, Race and Physical Handicap in Children's Preference for Other Children, 39 CHILD DEV. 467, 469, 478 (1968) ("For all subjects, the non-handicapped drawing was judged most liked regardless of color.").

${ }^{375}$ See generally SCOTCH, supra note 192, at 15-40.

${ }^{376}$ See Michael Ashley Stein, Under the Empirical Radar: An Initial Expressive Law Analysis of the ADA, 90 VA. L. REV. 1151, 1184-89 (2004) (interpreting disability life stories from an expressive law perspective). Earlier work by law and society scholar Lauren Edelman argues much the same point, i.e., that law can create an environment that institutionalizes compliance through gradual ritualization. See Lauren B. Edelman, Legal Ambiguity and Symbolic Structure: Organizational Mediation of Civil Rights Law, 97 AM. J. SoC. 1531, 1545 (1992) ("Legal change engenders a process of institutionalization whereby new forms of compliance are diffused among organizations and gradually become ritualized elements of organizational governance.").

${ }^{377}$ Most commentators consider ROBERT C. ElLICKSON, ORDER WITHOUT LAW: HOW NEIGHBORS SETTLE DiSPUTES (1991), to be the determining work in this area. See, e.g., Richard H. McAdams, Signaling Discount Rates: Laws, Norms, and Economic 
tion of how law shapes individual preferences by changing one's taste for specific outcomes, beyond the traditional effect ${ }^{379}$ of sanctions, ${ }^{980}$ through altering behavior. ${ }^{381}$ This can be because the new law either

Methodology, 110 YALE L.J. 625, 626 (2001) (opining that "[ $\mathrm{t}$ ] he seminal work in the lawand-economics camp is unquestionably Robert Ellickson's"). Several symposia have been convened on the subject. E.g., Symposium, Law, Economics and Norms, 144 U. PA. L. REv. 1643 (1996) (discussing the extralegal enforceability of norms); Symposium, The Legal Construction of Norms, 86 VA. L. Rev. 1577 (2000) (examining the law's effect on social norms); Symposium, Social Norms, Social Meaning, and the Economic Analysis of Law, 27 J. LEGAL STUD. 537 (1998) (addressing the emerging body of scholarship incorporating "social meaning and social norms into the study of legal rules").

${ }^{378}$ See generally Christine Jolls et al., A Behavioral Approach to Law and Economics, 50 STAN. L. REV. 1471, 1471 (1998) ("[L]aw and economics analysis may be improved by increased attention to insights about actual human behavior."); Symposium, The Legal Implications of Psychology: Human Behavior, Behavioral Economics, and the Law, 51 VAND. L. REV. 1495 (1998) (analyzing the impact on contract negotiations of negotiator biases for the status quo and inaction, as well as expressive law and economics, which examines how legal norms can alter social norms).

${ }^{379}$ Lawrence Lessig, The New Chicago School, 27 J. LEGAL STUD. 661, 673-80 (1998), describes this schism as one between the "Old Chicago School" whose adherents believe that norms act independently of law, and the "New Chicago School" who consider what impact laws have upon norms. For stalwarts of the Old Chicago School, for example Richard Posner, law and social norms scholarship enriches traditional law and economic work, but does not supercede it. Posner believes that social meaning is "something that society invests a sound or gesture with rather than something that comes ready-made in the sound or gesture or practice." Richard A. Posner, Social Norms, Social Meaning, and Economic Analysis of Law: A Comment, 27 J. LEGAL STUD. 553, 563 (1998).

${ }^{380}$ See, e.g., Eric A. Posner, Law and Social Norms: The Case of Tax Compliance, 86 VA. L. REV. 1781, 1806 (2000) (tax); Melvin A. Eisenberg, Corporate Law and Social Norms, 99 Colum. L. REv. 1253, 1253 (1999) (corporate law); Steven Hetcher, Creating Safe Social Norms in a Dangerous World, 73 S. CAL. L. REV. 1, 3 (1999) (torts); Elizabeth S. Scott \& Robert E. Scott, A Contract Theory of Marriage, in THE FALl AND RISE OF Freedom of Contract 201, 201 (F. H. Buckley ed., 1999) (marriage); Eric A. Posner, Family Law and Social Norms, in THE FALL AND RISE OF FREEdOM OF CONTRACT, supra at 256, 258-68 (family law); Michelle J. White, Why It Pays to File for Bankruptcy: A Critical Look at the Incentives Under U.S. Personal Bankruptcy Law and a Proposal for Change, 65 U. CHI. L. REv. 685, 686-87 (1998) (bankruptcy); Robert D. Cooter, Punitive Damages, Social Norms, and Economic Analysis, 60 LAW \& CONTEMP. PROBS., Summer \& Autumn 1997, at 73, 73 (punitive damages); Eric A. Posner, The Legal Regulation of Religious Groups, 2 LEGAL THEORY 33, 33-35 (1996) (religion); Richard H. McAdams, Group Norms, Crossip, and Blackmail 144 U. PA. L. REV. 2237, 2240 (1996) (blackmail); Dan M. Kahan, What Do Alternative Sanctions Mean?, 63 U. CHI. L. REV. 591, 593 (1996) (criminal punishment); McAdams, supra note 335, at 1008 (antidiscrimination law); Robert D. Cooter, Structural Adjudication and the New Law Merchant: A Model of Decentralized Law, 14 INT'L REv. L. \& ECON. 215, 215-16 (1994) (commercial law); Lisa Bernstein, Opting out of the Legal System: Extralegal Contractual Relations in the Diamond Industry, $21 \mathrm{~J}$. LEGAL STUD. 115, 115 (1992) (Jewish diamond merchants).

${ }_{381}$ See, e.g., Robert Cooter, Expressive Law and Economics, 27 J. LEGAL STUD. 585, 586 (1998) (describing the role of law in the development of social norms, and socioeconomic law and economics, which seeks to inject psychological and social factors related 
carries a symbolic social meaning, or because it affects the way individuals mediate that symbolic social meaning. ${ }^{382}$ What is crucial to this analysis is the nexus between law, norms, and social meaning. ${ }^{983}$ When designed appropriately, law can cause individuals to alter their own behavior because either the law induces them to change their tastes (internalization), creates a fear of bearing social sanctions (second order sanctions), or because of pressure brought to bear upon them through societal sanction (third order sanctions). ${ }^{384}$

to wealth and race into otherwise "neutral" economic analyses); Lawrence Lessig, The Regulation of Social Meaning, 62 U. CHI. L. REV. 943, 1019 (1995) (discussing regulation of social meaning as a way to regulate social conduct); Richard H. McAdams, A Focal Point Theory of Expressive Law, 86 VA. L. REV. 1649, 1650-53 (2000) [hereinafter McAdams, Focal Point Theory] (suggesting that law may be alternatively conceptualized for its expressive as well as its traditionally acknowledged enforcement functions); Richard $\mathrm{H}$. McAdams, An Attitudinal Theory of Expressive Law, 79 OR. L. REV. 339, 340 (2000) [hereinafter McAdams, An Attitudinal Theory] (highlighting the power of the approval or disapproval of law in shaping behavior); Cass R. Sunstein, On the Expressive Function of Law, 144 U. PA. L. REV. 2021, 2025 (1996) (arguing that "the expressive function of law makes most sense in connection with efforts to change norms and that if legal statements produce bad consequences, they should not be enacted even if they seem reasonable or noble").

382 Lessig, supra note 379.

${ }^{833}$ This account is, naturally enough for an emerging field, a synthesis of several views, rather than a univocal proposition. For example, Robert Cooter describes law as having two very different functions: enacting new obligations from the top down (as in the case of regulatory law) and growing from the bottom up (through social norm enforcement). Robert Cooter, Normative Failure Theory of Law, 82 CORNELL L. REV. 947, 949 (1997).

${ }^{384}$ An example commonly used in the literature to illustrate the effect of norm changes on behavior, is regulations prohibiting public smoking. See, e.g., RICHARD H. MCADAMS \& JANICE NADLER, A THIRD MODEL OF LEGAL COMPLIANCE: TESTING FOR EXPRESSIVE EFFECTS IN A HAWK/DOVE GAME 30 (IACM 17th Annual Conference Paper No. P-107, July 15, 2004) ("By publically announcing a state of affairs (e.g., 'No smoking here') law can make one of the multiple equilibria salient."), available at http://ssm.com/abstract=573582; McAdams, Focal Point Theory, supra note 381, at 1718-21 (discussing the labeling of public spaces as "smoking" and "non-smoking"); Sunstein, supra note 381, at 2032-34 ("In the relevant communities, the social meaning of smoking is not attractiveness and rebelliousness, but dirtiness and willingness to be duped."). Suppose a society exists in which most people smoke regularly, either because they consider it pleasurable, or because it is otherwise in keeping with regular social mores. Having now learned that smoking engenders costs in terms of both health care (cancer and emphysema, to name two examples) and environmental costs (e.g., poor air quality), the legislature passes a law that prohibits public smoking and fines violators. See, e.g., Dhammika Dharmapala \& Richard H. McAdams, The Condorcet Jury Theorem and the Expressive Function of Law: A Theory of Informative Law, 5 AM. L. \& ECON. REV. 1 (2003) (using the example of a ban on public smoking); MCADAMS \& NADLER, supra at 30 (same). The effect of this Act on Marlboro Man, an exuberant smoker, can be three-fold. Passage of the anti-smoking ordinance can (1) educate Marlboro Man that smoking really is a bad activity in which to engage, not only on his own behalf, but also for fellow citizens within reach of second-hand smoke and for 
Advancing this field, Alex Geisinger has proffered a "belief change" theory of expressive law that seeks to model and predict behavior in the context of social norm change. ${ }^{385}$ According to Geisinger, law impacts an individual's certainty regarding the consequences of her actions either by providing additional information about that action, or through its influence on an individual's "inferential reasoning process." ${ }^{886}$ This may occur either because the passage of a law has caused those who were ambivalent about particular conduct, "fence sitters," to lean toward an equilibrium, or because individuals with little information regarding an activity have now updated their knowledge and beliefs subsequent to the law's passage. ${ }^{887}$ In addition, as Richard McAdams and Robert Scott have each pointed out, the fact that a legislature has passed an ordinance signals to individuals that a majority of the franchise believes the rule is just. ${ }^{388}$ Thus, a belief change theory rests on the mechanisms by which a law's passage can influence an individual's behavior beyond the traditional notion of sanction. ${ }^{389}$

An expressive law analysis of the ADA indicates that the statute has the potential to legislate a belief change regarding individuals with disabilities in three ways: by informing the public about people with disabilities, by creating tri-order sanctions which alter the main-

animals who may choke on cigarette butts, and so change his desire to smoke; or (2) have no effect at all on Marlboro Man's personal desire to smoke, but make him fear the social condemnation of others who witness his public smoking, thus causing him to either curb his addiction or to practice it in private; and/or in combination with either or both of the previous two possibilities, (3) cause other members of Marlboro Man's society to bear social pressure and condemnation upon him until he abstains from public smoking. Stein, supra note 376, at 1173-74. For examples in the literature, see Dan M. Kahan \& Eric A. Posner, Shaming White Collar Criminals: A Proposal for Reform of the Federal Sentencing Guidelines, 42 J.L. \& ECON. 365, 368 (1999) (criminal shaming); Lessig, supra note 381, at 968-72 (dueling in the American South).

${ }^{385}$ Alex Geisinger, A Belief Change Theory of Expressive Law, 88 IOWA L. REV. 35, 38 (2002).

Id. at 63-65.

${ }^{387} I d$. at $68-69$. Drawing on studies by social psychologists, Geisinger points out that two factors serve as the main influences upon individual decisions as to whether to engage in particular behavior. They are that individual's personal attitude toward the behavior, and that individual's belief about how society at large regards the behavior. Combined, these two factors help determine how an individual will act in a given circumstance; in other words, a person's attitude (or belief certainty) about the consequences of satisfying a particular preference will govern whether she will satiate that preference. $I d$. at 55-56, 62-63.

${ }^{388}$ McAdams, An Attitudinal Theory, supra note 381, at 374; Robert E. Scott, The Limits of Behavioral Theories of Law and Social Norms, 86 VA. L. REv. 1603, 1615 (2000).

${ }^{389}$ Geisinger, supra note 385 , at 65. 
stream's behavior when interacting with the disabled, and by financially sanctioning discriminatory behavior.

The ADA educates mainstream individuals about people with disabilities who, unlike other minority groups, were empowered by civil rights legislation prior to a general elevation of social consciousness about their circumstances and capabilities. ${ }^{390}$ The statute does so by providing information through its legislative findings regarding the relative position of people with disabilities in society. ${ }^{991}$ This is especially true in the statute's statements about artificial exclusion as the cause of social exclusion, as opposed to inherent necessity. ${ }^{392}$ Additionally, by requiring that places of public accommodation be made readily accessible, ADA Title $\mathrm{III}^{393}$ affords people with disabilities a greater opportunity to participate in social function. Together, these features lessen the identity of the disabled as "other," and increase nondisableds' general familiarity with people with disabilities. Hence, following the ADA's promulgation, an employer who reads the statute (or consults with a lawyer as to its effects) is presented with a different vision of disability identity than that previously held. If she had lacked information regarding the role of disabled workers in society, the ADA has now updated her knowledge and beliefs. If she had been ambivalent about excluding disabled workers, the ADA's passage has now tipped her from being a fence-sitter toward accepting an inclusive equilibrium. Further, when an employer encounters people with disabilities in other areas of social activity, say, at a baseball game or when riding on public transportation, she becomes acclimated to the presence of persons from whom she was previously sheltered. This effect, in combination with the educational information contained in the ADA, will influence an employer to embrace the notion that people with disabilities belong in the mainstream, including the workplace. This is particularly true because the general impetus to exclude disabled people arises from benign neglect rather than from animus. ${ }^{\text {994 }}$

${ }^{390}$ See supra Part II.C.2 (illustrating the "unique civil rights chronology" of disabled Americans).

${ }^{391}$ See supra Part III.A.1 (discussing evidence about the treatment of people with disabilities that was presented during congressional hearings for the ADA).

${ }^{392}$ Id.

${ }^{399}$ See 42 U.S.C. $\S \S 12,181-12,189$ (2000) (specifying how places of public accommodation must make their facilities accessible to disabled persons).

${ }^{394}$ At the same time, it bears noting that expressive law scholarship, including the above account, may not adequately account for exogenous factors (for example, public transportation and health care) that have a powerful effect on the efficacy of antidis- 
Moreover, recall that Congress framed the ADA as a civil rights remedy rather than as a subsidy program. ${ }^{395}$ In doing so, the legislature articulated a group-based antisubordination theory that was to eviscerate practices of systemic subordination. ${ }^{396}$ As such, the ADA's goal is to alter employer behavior that contributes to unacceptable systemic patterns of social and economic subordination. ${ }^{397}$ This is premised on the notion that "employers who have a choice between participating in a subordinating system and working (at reasonable cost) against such a system have a moral obligation to respond in a way that reduces subordination." ${ }^{398}$

Framed as an antidiscrimination device, the ADA contains three levels of sanctions that can change social norms towards people with disabilities. As a first order sanction, the fact that Congress promulgated the ADA in this manner signals to individuals that the majority of the franchise believes that discriminating against the disabled is morally wrong. According to the belief change theory, and also extrapolating the points that Robert Cooter has made in a more general context, ${ }^{399}$ disability law can influence this process in two ways. First, in formulating a law regarding the disabled, and thereby creating a legal duty on behalf of employers, Congress can increase an individual employer's willingness to embrace that duty as part of her larger duties of citizenship. Second, individuals who believe they are required to obey the ADA's precepts will alter their preferences in order to behave in a manner conducive with that mandate. These two processes tip an individual's behavior toward a new equilibrium of behavior.

However, even if the ADA does not change the thinking of individual employers who would prefer to continue to exclude disabled workers, ${ }^{400}$ the framing of disability-based exclusion as a moral wrong can convince those employers not to exercise that preference in fear

crimination norms. For a discussion of the effect of some of these factors, see Stein, supra note 68.

${ }^{395}$ See supra Parts III.A.1, III.C.1 (outlining the evidence on which Congress based its decision to enact the ADA and which motivated Congress to frame the ADA as an "antidiscrimination device" as opposed to a subsidy program).

${ }^{396}$ See supra Part III.C; note 362 and accompanying text.

${ }^{397}$ Bagenstos, supra note 16 , at $837-38$.

${ }^{398}$ Id. at 838.

${ }^{399}$ See Robert Cooter, Do Good Laws Make Good Citizens? An Economic Analysis of Internalized Norms, 86 VA. L. REV. 1577, 1579 (2000) (discussing how the internalization of social norms affects civic acts).

${ }^{400}$ This argument works regardless of whether the employer is motivated by overt prejudice, benign paternalism, or ignorance of true cost. 
of social condemnation. This is true whether the censure would arise through formal or informal channels. Moreover, in combination with either or both of the previous two orders of sanction, the ADA can cause other members of an employer's society to bring social pressure and condemnation to bear upon her until she abstains from excluding disabled workers. Again, this is especially true when the exclusion of employees with disabilities arises from nonanimistic motivation.

Finally, the ADA has an effect for the traditional ("Old Chicago" ${ }^{401}$ reason that it creates monetary sanctions for discriminating against individuals with disabilities in their employment relationship. $^{402}$ Modeled after Title VII of the Civil Rights Act of $1964,{ }^{403}$ the ADA consciously tracks many of its provisions and offers several means for prosecuting claims. ${ }^{404}$ As described above, these means include the requirement that employers engage in an "interactive process" with disabled workers requesting workplace alterations, the formal filing of a disability discrimination complaint with a local EEOC office, mediation requests, and lawsuits brought against those employers either by aggrieved individuals or by the EEOC or the Department of Justice suing on their behalf. ${ }^{405}$ Each of these measures in turn carries increasingly heavy transaction costs for employers. Thus, regardless of whether employers continue to ultimately prove victorious in defending federal court suits, the $\mathrm{ADA}$ has added a transaction cost that reduces the overall utility to individual employers of exercising a preference for excluding disabled workers. Accordingly, by providing sanctions, the ADA motivates individual employers to reconsider acting on preferences that exclude disabled individuals from employment.

${ }^{401}$ See supra note 379 (discussing the differences between "Old Chicago" and "New Chicago" schools of thought on how norms interact with the law).

42 U.S.C. $\$ 12,112(2000)$.

${ }^{403}$ Civil Rights Act of $1964 \S 703,42$ U.S.C. $\S 2000 \mathrm{e}-2$ (a) (2000) (prohibiting employment practices that result in disparate treatment as well as those causing disparate impact).

${ }^{404}$ See Scotch, supra note 73, at 276 ("Using the Civil Rights Act of 1964 as a legislative template, the ADA seeks to eliminate the marginalization of people with disabilities through established civil rights remedies to discrimination."); see also S. REP. NO. $101-116$, at 43 (1989) (outlining which remedies and procedures under the Civil Rights Act of 1964 are also available pursuant to the ADA); H.R. REP. No. 101-485, pt. 2, at 82-83 (1990) (same); Burgdorf, supra note 4, at 463-64 (same).

${ }^{405}$ See supra text accompanying notes $341-351$ (discussing the three avenues that the ADA provides through which employers can correct informational asymmetries). 


\section{CONCLUSION}

Accepting ADA accommodations as an antidiscrimination remedy equivalent to those contained in its predecessors-especially the Civil Rights Act of 1964 on which the ADA was modeled-also requires accepting the equality of workers with disabilities. The canonical paradigm posits that economic reality and conceptual theory brightly and inexorably divide Title I from Title VII. Underlying this assertion is the precept that the disabled are fundamentally different from, and less capable than, other workers with atypical biology. The nearconsensus of legal scholars and Supreme Court Justices who adhere to the canonical paradigm acknowledges (to greater or lesser degree, depending upon their jurisprudential vision) the equality of women and African Americans and their wrongful historical exclusion from workplace opportunity. Yet these same scholars and judges rigidly adhere to an interpretation of law maintaining that people with disabilities are less able and more costly due to their inherently fixed impairments. Altering this canonical stance on disability equality requires a sea change in social attitude.

Perhaps the most expedient way to transform social norms is through increasing society's familiarity with a previously unknown group that it perceives, in sociological terms, as "other." ${ }^{\text {"06 }}$ Remember that a great deal of, if not the essential, support for the ADA's passage came from the "hidden army" of legislators with either personal (because they themselves had disabilities) or instinctive (because individuals they cared about were disabled) understanding of disabilityrelated stigma. ${ }^{407}$ As people age and are either themselves subject to a disabling condition, or come into contact with others who have disabilities, they become more sensitive to what it means to be cata-

${ }^{406}$ The qualification in text reflects a view that the most expedient way to transform legal norms is through widespread enforcement of those laws. That, at least, is the conclusion reached by Nobel Prize-winning economist James J. Heckman and three of his colleagues in the context of measuring Title VII's efficacy. See Donohue \& Heckman, supra note 333, at 1637-40 (explaining the apparent "enigma" during the 1960 s and 1970s in which African American advancements in employment and wages occurred at times when federal enforcement of civil rights legislation was weak); James J. Heckman \& Brook S. Payner, Determining the Impact of Federal Antidiscrimination Policy on the Economic Status of Blacks: A Study of South Carolina, 79 AM. ECON. REV. 138, 167-73 (1989) (examining data which illustrates the contribution that federal civil rights activity made to the improvement of African American economic status during the mid1960s). the bill)

${ }^{407}$ See supra Part II.C.2 (discussing the "hidden army" of legislators who supported 
logued as "disabled." 408 Indeed, the transmogrification of previously able-bodied individuals into people with disabilities is, among minority groups, an almost unique phenomenon that contributes to reducing the sense of "otherness." " 409 is for this reason that I have opposed proposals to narrow Title I's definition of disability to the "seriously" disabled, even though to date the largest category of people asserting Title I claims are able-bodied individuals who develop back-related maladies. ${ }^{410}$ Although largely grounded in anecdote, there is reason to believe that when a known and valued able-bodied employee becomes, through illness or injury, a known and valued employee with a disability, the disabled community as a whole benefits. ${ }^{411}$ In addition, because ADA Title III requires that places of public accommodation be made readily accessible, ${ }^{412}$ many employmentrelated accommodation costs should be subsumed by employers in

${ }^{408}$ Disabilities can manifest for a number of reasons. See, e.g., Chung-Yi Li et al., Longest Held Occupation in a Lifetime and Risk of Disability in Activities of Daily Living, 57 OCCUPATIONAL \& ENVTL. MED. 550, 550 (2000) (examining "the association between the longest held occupation in a lifetime and risk of disability in activities of daily living ... among elderly people ... in Taiwan"); Catherine A. Sarkisian et al., Correlates of Attributing New Disability to Old Age, 49 J. AM. Geriatrics Soc'Y 134, 134 (2001) (documenting the attribution of disability among women to old age); Judith A. Turner et al., Predictors of Chronic Disability in Injured Workers: A Systematic Literature Synthesis, 38 AM. J. INDUS. MED. 707, 708-09 (2000) (analyzing a variety of factors associated with chronic lower-back injuries). As reported by the Survey of Income and Program Participation, collected during 1991 and 1992, the average rates of disability by age among adults are: $13.6 \%$ for age $18-44$ years; $29.2 \%$ for age $45-64$ years; $44.6 \%$ for age $65-74$ years; $63.7 \%$ for age $75-84$ years; and $84.2 \%$ for age 85 years and over. John McNeil, Disabil ity, in Population Profile of THE UNITEd STATES 32, 32 (Bureau of the Census, Special Studies Series No. P23-189, 1995), available at http://www.census.gov/prod/1/pop /profile/95/14_ps.pdf. Additional census data having to do with disabilities is available at http://www.census.gov/hhes/www/disability.html (last revised July 8, 2004); see also Stein, supra note 202, at 64.

${ }^{409}$ Exceptions to this rule include those people of color who had previously "passed" as white or did not know their identities, as described, for example, by Jones, supra note 134, at 1517 n.137, and those few individuals who change their sex. See, e.g., Julie A. Greenberg, An Interdisciplinary and Cross-Cultural Analysis of Binary Sex Categories, in TRANSGENDER RIGHTS: History, POLITICS, AND LAW 212 (Paisley Currah \& Shannon Minter eds., 2003).

${ }_{410}$ This point was noted by economists Marjorie L. Baldwin and William G. Johnson in Dispelling the Myths About Work Disability, in NEW APPROACHES TO DISABILITY IN THE WORKPLACE 39, 44 \& fig.2 (Terry Thomason et al. eds., 1998).

${ }^{411}$ Stein, supra note 202, at 55; see also Morley Gunderson \& Douglas Hyatt, Do Injured Workers Pay for Reasonable Accommodation?, 50 INDUS. \& LAB. REL. REV. 92, 101 (1996) (finding that newly disabled workers at large firms received accommodations under Canada's similar law); Nancy R. Mudrick, Employment Discrimination Laws for Disability: Utilization and Outcome, 549 ANNALS AM. ACAD. POL. \& SOC. SCI. 53, 68 (1997) (finding the same for American workers under the ADA).

${ }_{412}^{4}$ U.S.C. $\$ \S 12,181-12,189$ (2000). 
their guise as owners or operators of those venues. Moreover, when states and local governments comply with Title III access requirements in the areas of public transportation and public accommodation as well as in the general construction of the physical environment, ${ }^{413}$ people with disabilities will have greater opportunity not only to physically participate in social function, but also to socially interact with mainstream society.

The ADA was enacted to achieve social and economic equality for people with disabilities, mainly through the provision of reasonable workplace accommodations. Yet legal scholars and Supreme Court Justices alike assert that the ADA's employment mandates distinguish the statute from traditional antidiscrimination measures, such as Title VII, because providing accommodations results in something more than equality for the disabled. Challenging this canonical belief, this Article argued that ADA-mandated accommodations are consistent with other antidiscrimination measures because each remedies artificial exclusion from employment opportunity by questioning the necessity of established workplace norms. It also placed the ADA within its historical context by illustrating how now-outdated social conventions about other workers with atypical biological identities, particularly women and African Americans, continue to keep workers with disabilities from equal labor market participation. Finally, this Article demonstrated how ADA accommodation expenses are an appropriate and reasonable remedy and provided economic and prudential reasons for why disability-related accommodations must be conceived of as antidiscrimination provisions (rather than as tax-and-spend subsidies) so as to alter social attitudes toward the disabled. 